Portland State University

PDXScholar

$11-9-1994$

\title{
Changes in Proteins Associated with Nitrogen Fixation and Iron Nutrition in the Marine Cyanobacterium Trichodesmium
}

Karen Marie Elardo

Portland State University

Follow this and additional works at: https://pdxscholar.library.pdx.edu/open_access_etds

Part of the Biology Commons

Let us know how access to this document benefits you.

Recommended Citation

Elardo, Karen Marie, "Changes in Proteins Associated with Nitrogen Fixation and Iron Nutrition in the Marine Cyanobacterium Trichodesmium" (1994). Dissertations and Theses. Paper 4902.

https://doi.org/10.15760/etd.6778

This Thesis is brought to you for free and open access. It has been accepted for inclusion in Dissertations and Theses by an authorized administrator of PDXScholar. Please contact us if we can make this document more accessible: pdxscholar@pdx.edu. 


\section{THESIS APPROVAL}

The abstract and thesis of Karen Marie Elardo for the Master of Science degree in Biology were presented November 9th 1994 and accepted by the thesis committee and the department.

COMMITTEE APPROVALS: , Chair

Dr. Leonard Simpson

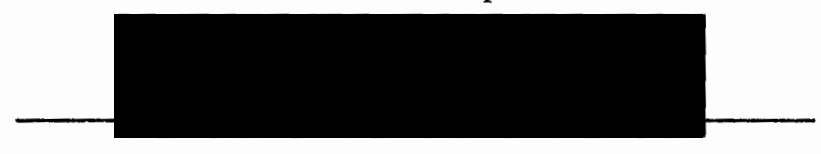

Dr. Richard Forbes
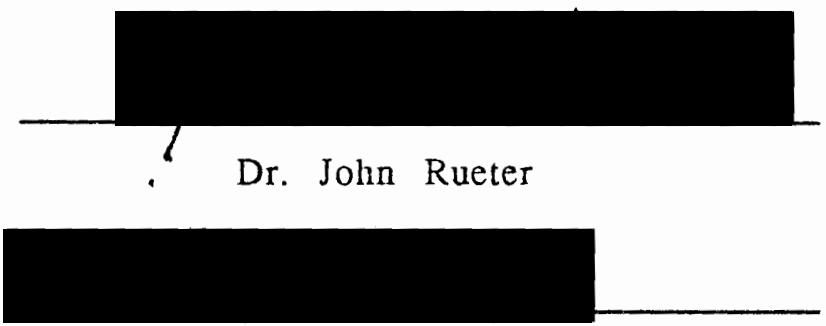

Dr. Curt Peterson

Repreresentative of the Office of Graduate Studies

DEPARTMENT APPROVAL:

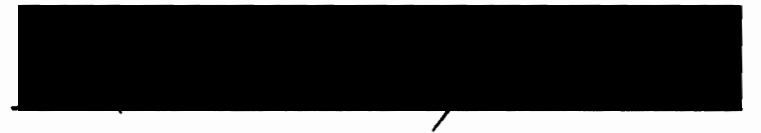

Dr. Leonard Simpson, Chair

Department of Biology

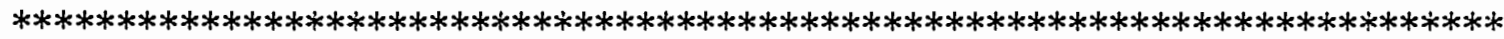

ACCEPTED FOR PORTLAND STATE UNIVERSITY BY THE LIBRARY

by on 25 fanecary 1995 


\section{ABSTRACT}

An abstract of the thesis of Karen Marie Elardo for the Master of Science in Biology: presented November 9, 1994.

Title: Changes in proteins associated with nitrogen fixation and iron nutrition in the marine cyanobacterium Trichodesmium.

This investigation tested the hypothesis that iron, as a micronutrient, will affect proteins in Trichodesmium and therefore affect nitrogen fixation. Changes in proteins that are a result of iron enrichment were compared to naturally occuring diel changes. Alterations in the iron protein of nitrogenase were compared to nitrogen fixation rates using the acetylene reduction technique. The observed changes in proteins were compared in Trichodesmium colonies from the Caribbean Sea and the Sargasso Sea.

Trichodesmium colonies were monitored for protein and iron content over a diel period on two cruises. The changes in protein and iron content in Trichodesmium colonies were variable but at times showed a cyclic diel pattern. Changes in protein bands on SDS-PAGE showed consistent changes in the banding pattern of a low molecular weight protein that responded to iron nutrition and time of day (Elardo and Rueter 1990). These changes were similar to changes in the iron protein of nitrogenase which also responded to changes associated with iron nutrition and time of day (Elardo 1991). 
Trichodesmium appear to alter certain proteins which appear as changes in banding patterns in response to environmental factors such as nutrients, temperature and light.

My research shows that the pattern of modification of the iron protein of nitrogenase differs in colonies from the Caribbean Sea compared to those from the Sargasso Sea (Elardo 1991). The Caribbean Sea population in February had a clear pattern of active and inactive forms (day vs. night) of the enzyme. The Sargasso Sea population of Trichodesmium spp. had both forms of the enzyme at all times of the day during April and May when $\mathrm{NO}_{3}^{-}$is present in the euphotic zone due to recent mixing. These differences between the two populations may be due to different environmental conditions since the Caribbean Sea is permanently stratified, warmer and nutrient-depleted throughout the year. The Sargasso Sea undergoes seasonal breakdown of the thermocline during winter months, resulting in an injection of nitrate from deeper water, and minimum temperatures of $18^{\circ} \mathrm{C}$. 
CHANGES IN PROTEINS ASSOCIATED WITH NITROGEN FIXATION AND IRON NUTRITION IN THE MARINE CYANOBACTERIUM TRICHODESMIUM

by
KAREN MARIE ELARDO

A thesis submitted in partial fulfillment of the requirements for the degree of

MASTER OF SCIENCE

in

BIOLOGY

Portland State University

1995 


\section{AKNOWLEDGEMENTS}

I thank Dr. Leonard Simpson, my thesis advisor, for without him this thesis would not have been completed. I thank Dr. John Rueter for travel to cruises in 1990, for generous supplies, chemicals and use of equipment. I thank Dr. Deborah Duffield for advise and encouragement. I thank Dr. Nora Terwilliger for teaching me SDSPAGE and other very useful techniques and the American Heart Association Summer Fellowship for support which enabled me to work with Dr. Terwilliger. I thank Dr. Jonathan Zehr for helpful suggestions on SDS-PAGE technique and for the gift of primary antiserum to dinitrogenase reductase. I thank Dr. Birgitta Bergman for the generous gift of primary antisera to phycoerythrin and dinitrogenase reductase. I thank Drs. Ed Carpenter and Doug Capone for allowing me shiptime on six cruises in the Caribbean Sea, for their generous assistance in travel to two cruises and access to equipment. I thank Dr. Anthony Michaels for his advisory role at the Bermuda Biological Station for Research (BBSR), and the BBSR Graduate Intern Program that allowed my study to continue in the Sargasso Sea. I thank the Roger Thayer-Stone Fellowship for support during the final writing phase of this thesis. I thank the Bermuda Atlantic Timeseries study for providing CTD profiles and nitrate + nitrite vertical profiles. I thank Kjell Gundersen for his help preparing the figures which greatly enhanced this thesis. 


\section{TABLE OF CONTENTS}

PAGE

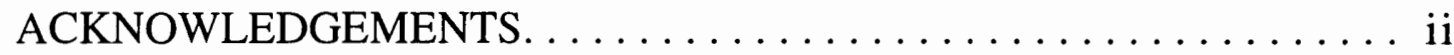

LIST OF TABLES $\ldots \ldots \ldots \ldots \ldots \ldots \ldots \ldots \ldots \ldots \ldots \ldots \ldots \ldots$

LIST OF FIGURES $\ldots \ldots \ldots \ldots \ldots \ldots \ldots \ldots \ldots \ldots \ldots \ldots$ vii

SECTION

I INTRODUCTION $\ldots \ldots \ldots \ldots \ldots \ldots \ldots \ldots \ldots$

Literature Review . . . . . . . . . . . . 2

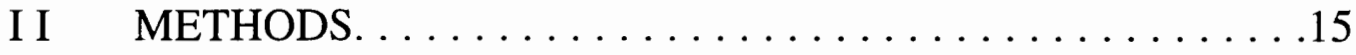

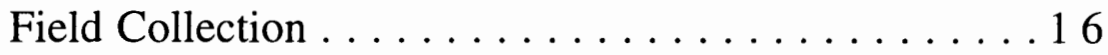

Bicinchoninic Acid Protein Assay Reagent for

Total Cellular Protein . . . . . . . . . . . . . . . 17

Acid Leachable Iron by the Ferrozine Assay. . . . 19

Development of the SDS-PAGE Method ...... 21

Low Molecular Weight SDS-PAGE . . . . . . . 25

Iron and Dust Incubations for SDS-PAGE . . . . . 25 
Western Blot Immunoassays . . . . . . . . . 26

Acetylene Reduction Assay . . . . . . . . . 27

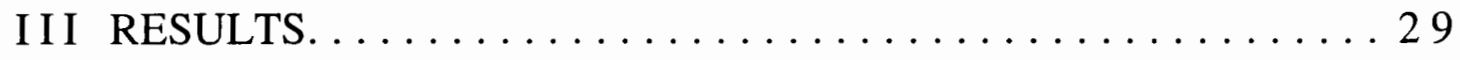

Protein and Iron Content . . . . . . . . . 29

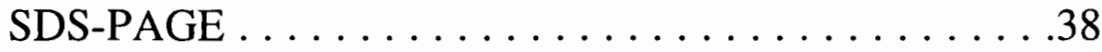

Western Blot Immunoassays . . . . . . . . . . 46

Hydrography of the Sargasso and Caribbean

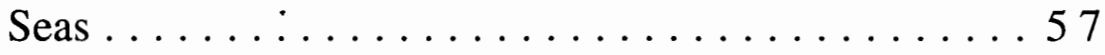

Acetylene Reduction and Iron

Additions . . . . . . . . . . . . . 57

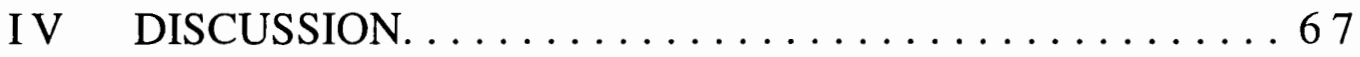

Protein and Iron Content ...........6 67

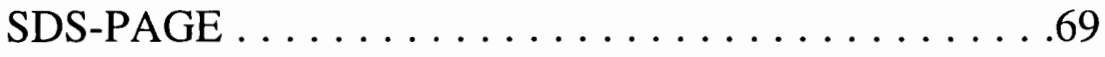

Western Blot Immunoassays . . . . . . . . . 70 
Hydrographical influence on dinitrogenase reductase of Trichodesmium in the Sargasso and Caribbean Seas ............... 73 Acetylene Reduction Assay and Iron Additions . . . . . . . . . . . . . 75

Conclusion ................ 78

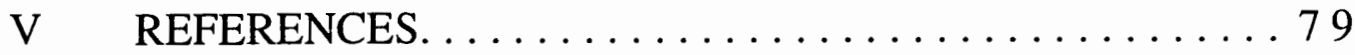

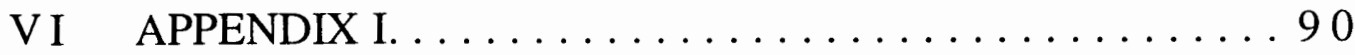

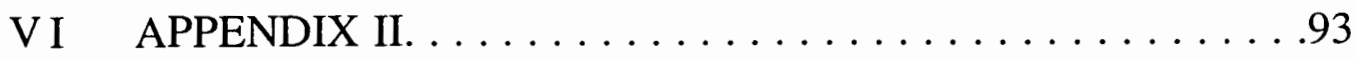




\section{LIST OF TABLES}

TABLE

PAGE

I A selection of reported nitrogen fixation rates and nitrogen turnover times for Trichodesmium in the Atlantic Ocean . . . . . . . . . . . . . . . 6

I I Average acetylene reduction rates for Trichodesmium in a short term incubation with iron additions . . 663

III Average acetylene reduction rates for Trichodesmium in a long term incubation with iron and EDTA additions ................. 64 


\section{LIST OF FIGURES}

1 Drawing of puff and tuft colonies $\ldots \ldots \ldots \ldots$

2 Filtration apparatus $\ldots \ldots \ldots \ldots \ldots \ldots \ldots$

3 Protein content in Trichodesmium colonies as a function of time in April 1990 from the Caribbean Sea ......................... 0

4 Protein content in Trichodesmium colonies as a function of time in February 1991 from the Caribbean Sea . . . . . . . . . . . . . . . . 31

5 Daily variation of acid leachable iron content in Trichodesmium colonies in January 1990 from the Caribbean Sea ............... 33

6 Daily nitrogenase activity and iron content in Trichodesmium colonies in January 1990 . . . . . 34

7 Acid leachable cellular iron content in Trichodesmium colonies as a function of time of the day in April 1990 from the Caribbean Sea . . . . . . . . . . 35

8 Acid leachable cellular iron content in Trichodesmium colonies as a function of time of the day in

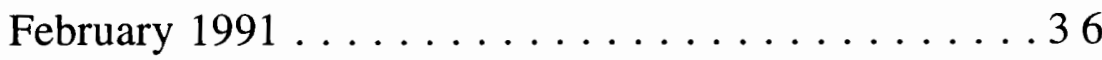

9 Pretreatment prior to the Ferrozine assay and the protein content in Trichodesmium colonies... 37 
10 Protein nitrogen to iron ratios in Trichodesmium colonies from the Caribbean Sea . . . . . . . . 39

11 SDS-PAGE of Trichodesmium colonies in January 1990 from the Caribbean Sea . . . . . . . . . . . . 41

12 SDS-PAGE of Trichodesmium colonies in an iron addition and a diel experiment on April 6th, 1990 from the Caribbean Sea . . . . . . . . . . . 42

13 SDS-PAGE of Trichodesmium colonies in a diel and an iron addition experiment in February 1991 from the Caribbean Sea ...............44 3

14 SDS-PAGE of Trichodesmium colonies in a diel and an iron addition experiment in February 1991 from the Caribbean Sea . . . . . . . . . . . . . 44

15 Immunoassay (anti-phycoerythrin) of Trichodesmium colonies in a diel and an iron addition experiment in February 1991 from the Caribbean Sea . . . 47

16 Schematic diagram of 'modification' of the iron protein of nitrogenase and how it will appear on a Western blot .................4 48

17 Immunoassay (anti-dinitrogenase reductase) of Trichodesmium colonies in a diel and an iron addition experiment in February 1991 from the Caribbean Sea ................. 50 
18 Immunoassay (anti-dinitrogenase reductase) of

Trichodesmium colonies in an iron addition

experiment on 14 February, 1991 from the

Caribbean Sea ................... 51

19 Immunoassay (anti-dinitrogenase reductase) of

Trichodesmium colonies in a diel and an iron

addition experiment in April 1991 from

the BATS station in the Sargasso Sea . . . . . . . 53

20 Immunoassay (anti-dinitrogenase reductase) of

Trichodesmium colonies in an iron addition

experiment on April 23rd, 1991 from

Hydrostation ' $S$ ' in the Sargasso Sea . . . . . . . 5 54

21 Immunoassay (anti-dinitrogenase reductase) of

Trichodesmium colonies (Puff and Tuft

comparison) on May 9th, 1991 from

Hydrostation ' $S$ ' in the Sargasso Sea ........ 55

22 Immunoassay (anti-dinitrogenase reductase) of

Trichodesmium colonies (Puff and Tuft

comparison) in a diel experiment in May,

1991 at BATS station in the Sargasso Sea . . . . . 56

23 Vertical profile of nitrate + nitrite at BATS station in the Sargasso Sea in April and May 1991 ... 58 
24 Vertical profile of Salinity, Temperature and Fluorescence at BATS station in the Sargasso Sea on 30 April, $1991 \ldots$. . . . . . . . . . . . . . . . .59

25 Vertical profile of salinity, temperature and fluorescence at BATS station in the Sargasso Sea on 13 May, $1991 \ldots \ldots \ldots \ldots \ldots \ldots$

26 Vertical profile of salinity and temperature in the Caribbean Sea on February 4 th, $1991 \ldots \ldots$. . . 61

27 Acetylene reduction as a function of time of the

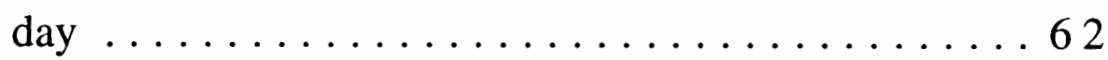




\section{INTRODUCTION}

Marine nitrogen fixation may be an important source of new nitrogen to oligotrophic oceans (Karl et al. 1992). The supply of nutrients such as nitrogen to the euphotic zone represents one of the main controls of the ocean carbon cycle. Iron may be a limiting nutrient for nitrogen fixation in Trichodesmium (Rueter 1988). In his study he found that natural populations of Trichodesmium had increased rates of nitrogen and carbon fixation rates when incubated with iron. Recently, Paerl et al. (1994) concluded that nitrogen fixation in Trichodesmium may be limited by iron.

Iron in different forms (soluble and particulate) was used in this study to observe changes in proteins associated with nitrogen fixation and to compare changes to nitrogen fixation rates. The result would determine if changes in structure of the nitrogenase complex occur, when exposed to iron, and if this was reflected in changes in rates of nitrogen fixation.

Since nitrogen fixation in Trichodesmium is light-dependent, an attempt to observe an increase in protein content in the dark hours following the nitrogen fixation period was conducted by collecting colonies over a diel period. Colonies were also assayed for cellular iron content to determine what levels of iron the colonies had naturally before iron additions. 
Finally, colonies from two different environments, the Caribbean Sea and the Sargasso Sea, were examined for changes in the iron protein of nitrogenase that are a result of different nutrient regimes.

\section{Literature Review}

Trichodesmium spp. is a non-heterocystous, filamentous colonial cyanobacterium found in tropical and subtropical seas. The macroscopic colonies of $T$. thiebautii have two distinct morphologies, colloquially termed "puffs" and "tufts" (Figure 1). Trichodesmium spp. is considered to be the major nitrogen-fixing organism in the marine plankton (Carpenter 1983a). Nitrogen fixation is the reduction of atmospheric nitrogen, catalyzed by the nitrogenase enzyme complex, into ammonia which is then converted to organic compounds. Nitrogen fixation by Trichodesmium was first reported by Dugdale et al. (1961) in the Sargasso Sea using the ${ }^{15} \mathrm{~N}$ tracer method. It was noted in the Dugdale et al. study that nitrogen fixation occurred only in the light and that an enrichment to the incubation flasks of a mixture of phosphate, vitamins and trace metals inhibited nitrogen fixation completely. Dugdale et al. (1961) suggested that their results show primary production in an oligotrophic ocean may not be limited by nitrogen. Menzel and Ryther (1961) suggested that iron may be the element critically limiting primary production in the Sargasso Sea near Bermuda. In a later study, Dugdale et al. (1964) demonstrated high rates of nitrogen previous 1961 study. Goering et al. (1966) reported the first in situ 


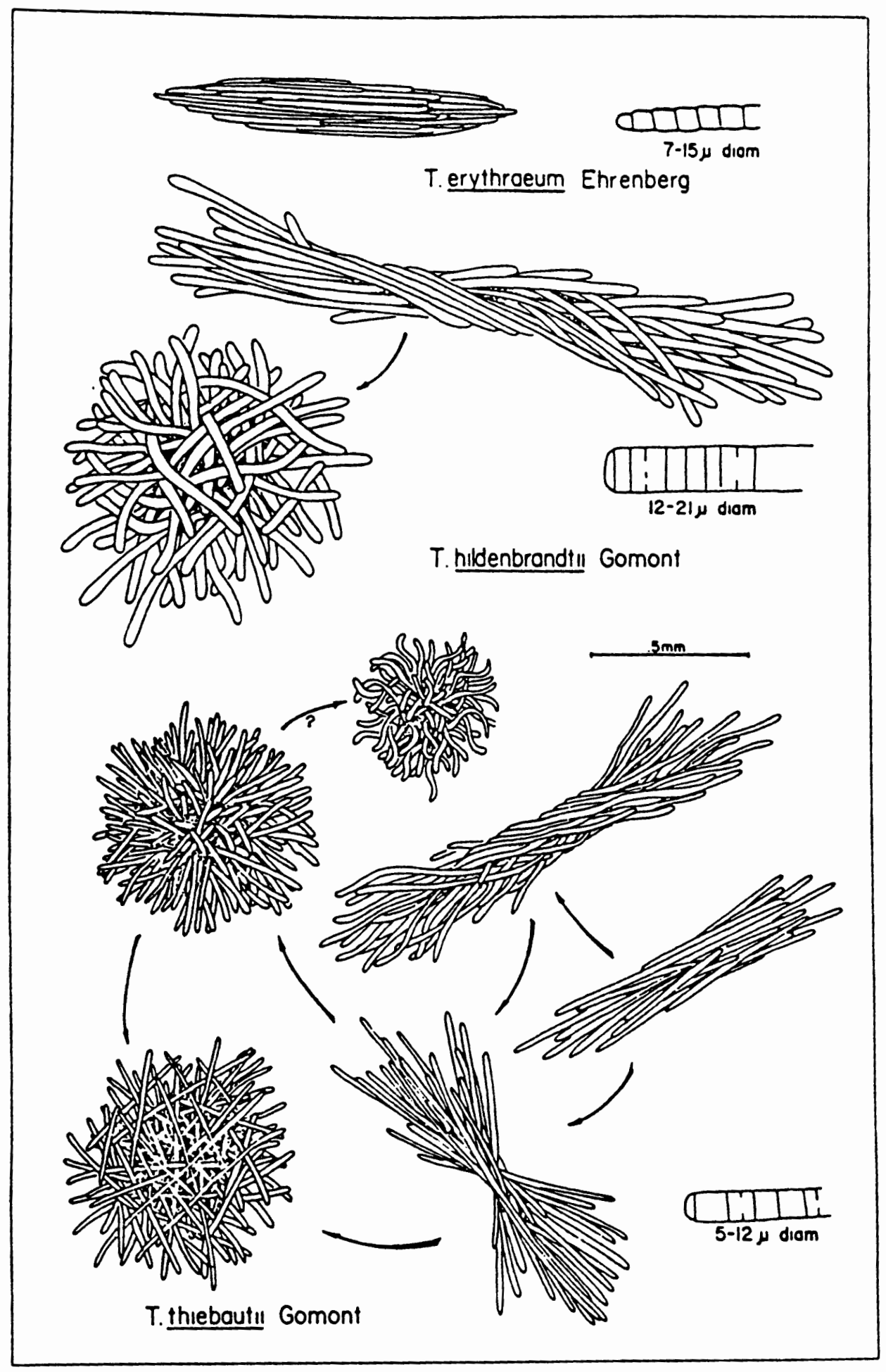

Figure 1. Drawing of Trichodesmium puff and tuft colonies. (from Borstad, 1978). 
rates of nitrogen fixation, ammonia uptake, and nitrate uptake by Trichodesmium in the tropical Atlantic Ocean.

Goering et al. (1966) showed by using the $15 \mathrm{~N}$ technique that significant amounts of nitrogen fixation can occur during blooms of Trichodesmium. They also showed that Trichodesmium can actively utilize ammonia and nitrate concurrently with nitrogen fixation. In a later study, Carpenter (1973) presented data showing rates of nitrogen fixation by Trichodesmium in the Sargasso Sea as revealed by the acetylene reduction assay. Although both techniques are valid measurements of the fixation of nitrogen, it has been argued that each technique could result in different errors. Carpenter (1973) suggested that acetylene reduction is a sensitive technique and measures gross nitrogen fixation (all products), whereas the $15 \mathrm{~N}$ technique measures net nitrogen fixation (only the ${ }^{15} \mathrm{~N}$ retained in the cell, excluding extracellular losses). In a comparison of both techniques using soybean root nodules, Bergersen (1970) concluded that caution should be observed in the application of the acetylene reduction assay to quantify nitrogen fixation due to the significant variation in the molar conversion ratio. The differences in the two techniques and methods employed by Goering et al. (1966) and Carpenter (1973) resulted in the use of different units to quantify nitrogen fixation by Trichodesmium. This has presented a discrepancy when comparing the two techniques and methods applied in the 1960s and 1970s. This discrepancy compounded with the variability in nitrogen fixation rates reported, has precluded an accurate assessment for this organism. 
Carpenter and McCarthy (1975) reported that the geographical variation in $\mathrm{N}_{2}$ fixation over the western Sargasso Sea spanned two orders of magnitude; they attributed this variation to spatial heterogenity and variable $\mathrm{N}_{2}$-fixing activity of Trichodesmium. Carpenter and Price (1977) compared nitrogen fixation, distribution and primary production of Trichodesmium spp. in the Sargasso and Caribbean Seas. They concluded that Trichodesmium is significant to the nitrogen cycle in the Caribbean Sea but not in the Sargasso Sea. Later, Carpenter et al. (1987) reported cellular $\mathrm{N}$ turnover times of 1.48 days in the Sargasso Sea and 1.13 days in the Caribbean Sea. By comparing their data with $\mathrm{N}$ turnover times reported in the literature, the authors demonstrated the variability of nitrogen fixation rates by Trichodesmium.

Thus, variability in nitrogen fixation rates has precluded an accurate assessment for this organism. This variability is compounded by inconsistent use of units to express rates resulting in difficulty comparing studies. Table I illustrates this with selected reported rates for Trichodesmium in the Atlantic Ocean.

Marine nitrogen fixation may be an important source of new nitrogen to oligotrophic oceans (Karl et al. 1992). New nitrogen is associated with "new production" which is defined as all primary production associated with newly available nitrogen from outside the euphotic zone $\left(\mathrm{NO}_{3}{ }^{-}\right.$or $\mathrm{N}_{2}$ ) (Dugdale and Goering, 1967). Carpenter and Capone (1992) have calculated nitrogen fixation rates of massive blooms of the marine diazotrophic cyanobacterium Trichodesmium to be $5.4 \mathrm{Tg}\left(5.4 \times 10^{12} \mathrm{~g}\right) \mathrm{N} \mathrm{yr}^{-1}$ fixed. Previous estimates (Carpenter 
A SELECTION OF REPORTED NITROGEN FIXATION RATES AND NITROGEN TURNOVER TIMES (td) FOR TRICHODESMIUM IN THE ATLANTIC OCEAN

Reported rate

$0.13 \mu \mathrm{g} \mathrm{N}$

$0.32 \mu \mathrm{g} \mathrm{N} / 1^{*} \mathrm{~h}$

$0.044 \mu \mathrm{g} \quad \mathrm{N} / \mathrm{col}^{*}$ day

$0.069 \mathrm{pg} \mathrm{N} /$ cell*h

$0.033 \mathrm{pg} \mathrm{N} /$ cell*h

$22.1 \mathrm{fg} \mathrm{N}_{2} /$ cell*h

$0.38 \mathrm{ng} \quad \mathrm{N} /$ trichome*day td

Author(s)

Dugdale et al. 1961

825

47

92

105

31

1.48
Goering et al. 1966

Carpenter 1973

Carpenter and McCarthy 1975

Carpenter and Price 1977

McCarthy and Carpenter 1979

Carpenter et al. 1987 
1983a, Capone and Carpenter 1982) of nitrogen fixation rates were based on non-bloom periods and totaled $4.7 \mathrm{Tg}^{-1}$. This underestimate of nitrogen fixation by Trichodesmium is due to previous sampling during non-bloom conditions. When bloom and non-bloom fixation rates are totaled, the amount of $\mathrm{N}$ fixed is more than double the previous estimates.

The supply of nutrients such as nitrogen to the euphotic zone represents one of the main controls of the ocean carbon cycle. Undersampling of pelagic oceanic environments has obscuredreliable estimates of the quantitative importance of nitrogen fixation in new production (Carpenter and Price 1977, Howrath et al. 1988, Capone and Carpenter 1982). Presently, the process of nitrogen fixation has not been included in ecosystem models (Legendre and Gosselin 1989). New nitrogen is most commonly referred to as sources of nitrogen from the upward transport of $\mathrm{NO}_{3}$ - from below the euphotic zone (Dugdale and Goering 1967, Eppley and Peterson 1979) and atmospheric deposition (Dugdale and Goering 1967, Knap et al. 1986). Understanding the factors that regulate nitrogen fixation and possible nutrient limitations of this process has become essential in understanding the global oceanic nitrogen cycle and the contribution of this process in primary productivity.

Most nitrogen-fixing cyanobacteria contain heterocysts; a specialized thick walled cell that is the site of nitrogen fixation. This structure protects nitrogenase from oxygen diffusion. Since Trichodesmium colonies do not contain heterocysts, it is an intriguing 
question how this organism can perform photosynthesis and nitrogen fixation at the same time. This question has yet to be resolved. Saino and Hattori (1978) demonstrated a diel variation in nitrogen fixation in which nitrogen fixation occured in the daylight in the presence of oxygen evolved through photosynthesis. This creates a paradox, since exposure to oxygen rapidly and irreversibly inactivates nitrogenase. The basis for this diel variation in nitrogenase activity was investigated by Capone et al. (1990). They concluded that the diel cycle of nitrogenase activity resulted from $d e$ novo synthesis of nitrogenase each morning and from inactivation and degradation of nitrogenase in the late afternoon and night. Carpenter and Price (1977) proposed that nitrogen fixation was restricted to cells in the center of the colony where they observed reduced pigment in the central cells. Bryceson and Fay (1981) found that nitrogenase activity was directly related to colony bundleness, thus supporting the earlier work of Carpenter and Price. Saino and Hattori (1982) found that single trichomes were able to fix nitrogen, demonstrating that colony formation was not nessesary for nitrogen fixation. Saino and Hattori also showed that Trichodesmium colonies evolved hydrogen under argon and suggested that uptake hydrogenase protects nitrogenase from oxygen. However, Scranton (1983, 1984) and Scranton et al. (1987) demonstrated that hydrogen production was much slower than nitrogen fixation rates and suggested that nitrogen fixation and hydrogen production were not coupled in this system. Paerl and Bebout (1988) reported direct measurement of $\mathrm{O}_{2}$-depleted microzones in the center of the colony 
which would optimize nitrogen fixation. Carpenter et al. (1990) reevaluated this hypothesis. They found that further measurements did not reveal microzones and that there was no pigment differentiation between the center or the peripheral region trichomes in Trichodesmium. These investigators suggested that there is no single oxygen protection mechanism, but that several processes may work together. They also suggested that an internal enzymatic process may be involved in oxygen protection of nitrogenase. Ohki et al. (1991a) using cultures of Trichodesmium, presented a model of activation-deactivation of the iron protein of nitrogenase that may be involved in regulation of nitrogenase.

The nitrogenase enzyme complex is composed of two components, Component 1 (the Mo-Fe protein) dinitrogenase and component 2 (the Fe-protein) dinitrogenase reductase. Dinitrogenase reductase is composed of two identical subunits whereas dinitrogenase is a tetramer composed of two different types of subunits. The nitrogenase complex is irreversibly destroyed by oxygen and different strategies are utilized by cyanobacteria to protect nitrogenase from inactivation (Gallon 1981, Gallon 1989, Gallon 1992, Fay 1992). These strategies include temporal separation of photosynthesis and nitrogen fixation, spatial separation by forming heterocysts, reducing the concentration of oxygen by high metabolic rates, balanced destruction of nitrogenase by continual synthesis of the enzyme and modification of the enzyme so it is oxygen resistant. Evidence by Ohki et al (1991a, 1991b and1992) and Zehr et al. (1993) as well as diel studies presented here show 
that Trichodesmium has the capacity to modify dinitrogenase reductase.

Modification of dinitrogenase reductase has been observed in the photosynthetic bacterium Rhodospirillium rubrum (Preston and Ludden 1982). This modification involves the ADP ribosylation of one of the subunits of dinitrogenase reductase (Ludden and Burris 1978, Pope et al. 1985). Modification of dinitrogenase reductase in cyanobacteria has been demonstrated in Anabaena (Smith et al. 1987, Reich and Boger 1989, Ernst et al. 1990a and 1990b) although the molecular basis for this modification is unknown. When compared to photosynthetic bacteria, Smith et al. (1987) found that modification of nitrogenase in Anabaena did not result in the inactivation of the nitrogenase system. Reich and Boger (1989) found that inactivation of nitrogenase with ammonia addition was correlated with equal amounts of modified and non-modified forms of the iron protein in Anabaena. Modification of dinitrogenase reductase in Trichodesmium has been documented by Ohki et al. (1991a, 1991b and1992) in cultures and Zehr et al. (1993) in natural populations. This modification has been found in diel studies to occur at night. The exact mechanism for daytime protection against oxygen is yet unclear. Recent work by Bergman and Carpenter (1991) show that nitrogenase activity is confined to certain trichomes (filaments within a colony) which are spatially separated. In their study they demonstrated by immunogold localization and transmission electron microscopy that nitrogenase in Trichodesmium is randomly distributed in $10-40 \%$ of the trichomes within a colony. 
Recent work by Kana (1993) proposes that rapid oxygen cycling may contribute to the protection of nitrogenase by reducing the oxygen tension within the cell or colony. Kana suggests that this rapid oxygen cycling may help explain the low oxygen zones sometimes found in Trichodesmium colonies. Trichodesmium are unique among non-heterocystous filamentous cyanobacteria in that they perform nitrogen fixation and oxygenic photosynthesis at the same time and appear to use a unique combination of protective strategies.

There is a high requirement for iron in nitrogen fixation, since nitrogenase uses approximately 34 iron atoms to catalyze the reaction of $\mathrm{N}_{2}$ to $2 \mathrm{NH}_{3}$ (Orme-Johnson 1992). The major source of iron to the ocean photic zone is from atmospheric transport of aeolian dust (Duce and Tindale 1991, Duce et al. 1991, Duce 1986). Duce (1986) calculated that atmospheric input can account for $30 \%$ to $96 \%$ of the iron input to the Sargasso Sea region and $16 \%-76 \%$ to the North Pacific gyre. Moore et al. (1984) calculated that $10 \%$ of the iron from atmospheric dust is leachable and in the biologically usable ferrous form. The low solubility of the stable oxidation state of iron (Fe III) in oxic seawater limits the assimilation of the soluble ionic species by phytoplankton. Iron is essential for many metabolic processes, including photosynthesis, nitrogen assimilation and nitrogen fixation, which creates a high demand for iron by phytoplankton. The concept of iron limitation of primary production has recently gained attention as a result of the work of John Martin and colleagues (Martin and Fitzwater 1988, Martin and Gordon 1988, 
Martin et al. 1989, Martin et al. 1991). These investigations concluded that phytoplankton growth in major nutrient-rich waters is limited by iron deficiency.

Menzel and Ryther (1961) determined that iron was the effective component that enhanced ${ }^{14} \mathrm{C}$ uptake by phytoplankton in the nutrient-poor Sargasso Sea. These authors found that nitrogen and phosphorus alone did not enhance uptake but they did so after samples were previously incubated in iron for 24 hours. This demonstrates Liebig's law of the minimum which states that "growth of a plant is dependent on the minimum amount of foodstuff presented" (Liebig 1840 in Parsons et al. 1984). The idea that the rate of a biological process may be determined by a single limiting factor is more clearly demonstrated in nutrient-rich upwelling areas that are known to have low atmospheric dust loads. Studies in permanently stratified, nutrient-poor areas of the ocean that are readily exposed to atmospheric dust are complicated by the possibility of co-limitation of several nutrients. Ryther and Guillard (1959) pointed out this possibility in their enrichment studies in the Sargasso Sea where they found silicate and one or more of the components in the iron-trace metal mixture to limit photosynthesis rather than nitrogen or phosphorus. Menzel et al. (1963) conducted enrichment studies on Sargasso Sea waters and found that the final growth rate of a population of phytoplankton was a function of time. For example, in three-day experiments iron appeared essential; and in seven-day experiments nitrogen and phosphorus alone produced large populations. These workers also found that the final population 
of species composition was determined by the addition of specific nutrients and that separate enrichments of aluminium produced growth curves similar to those from additions of iron (both elements were in combination with nitrogen and phosphorus). Subba Rao and Yeats (1984) investigated the effect of iron on phytoplankton in the Sargasso Sea and found that incubations of four hours had no effect on photosynthesis but incubations of 72 hours enhanced carbon assimilation.

Elder and Horne (1977) investigated the biostimulatory capacity of dissoved iron and concluded that iron was an important nutrient controlling nitrogen fixation in a freshwater resevoir. These authors found the biostimulatory capacity of iron to be particular to nitrogen-fixing cyanobacteria. Wurtsbaugh and Horne (1983) found that nitrogen fixation in freshwater cyanobacteria could be stimulated as much as $500 \%$ above the control levels by iron additions. Wurtsbaugh et al. (1985) found nitrogen fixation in a tropical alpine lake to be stimulated by additions of iron but only significantly in one experiment. Rueter and Ades (1987) concluded in a study on the chlorophyte, Scenedesmus quadricauda, that iron plays a crucial role in the bioenergetics of carbon and nitrogen metabolism.

Rueter (1988a) found that natural populations of Trichodesmium responded to iron additions (as $\mathrm{FeCl}_{3}$ ) with increased nitrogen and carbon fixation rates when incubated for two days. Rueter used concentrations of iron ranging from $10^{-8}$ to $10^{-6} \mathrm{M}$ and found stimulation of nitrogen fixation at the highest iron 
concentration. The lowest iron concentration was not always stimulatory. Rueter et al. (1990) showed stimulation of nitrogen fixation in cultures of Trichodesmium NIBB 1067 with iron concentrations of $10^{-8}$ and $10^{-7} \mathrm{M} \mathrm{Fe}$ when incubated for 15 days.

More recently, Paerl et al. (1994) demonstrated ironstimulated growth in nitrogen fixation and growth in natural populations and in cultured Trichodesmium spp. Stimulation by iron occurred at $1 \mu \mathrm{M} \mathrm{FeCl} 3$ and EDTA-chelated $\mathrm{FeCl}_{3}$ in both short term (24-48 hours) and long term (5-11 days) experiments.

Concentrations of $1 \mu \mathrm{M} \mathrm{Fe}$ do not occur in nature but apparently are required to produce observable levels of nitrogen fixation in this organism. The authors concluded that primary production and nitrogen fixation in oligotrophic waters may be limited by iron.

These investigators have shown that iron is important for nitrogen fixation. This study investigated the response of nitrogen fixation in Trichodesmium to near ambient concentrations of iron and to aeolian dust particles. Using the combination of immunoassays and acetylene reduction rates, the influence of iron on nitrogenase was compared to changes that are a result of oxygen protection. 


\section{METHODS}

Trichodesmium are not commonly cultivated; therefore, field samples were collected for use in the experiments presented here. The Ferrozine Assay was used to determine acid leachable iron content on samples collected during peak nitrogenase activity and on diel time scales. The Pierce Bicinchoninic Acid (BCA) Protein Assay Reagent was used to determine cellular protein of samples collected on a diel time scale. Protein nitrogen was estimated from protein content assuming an average nitrogen content of cell protein of $14 \%$ (Dayhoff et al. 1965). Iron and nitrogen ratios were determined for samples collected on diels.

To further observe changes in proteins on a diel time scale, Sodium Dodecyl Sulfate Polyacrylamide Gel Electrophoresis (SDSPAGE) was used to detect changes in proteins on diels and with the addition of iron in different forms. Iron-specific stains were used to detect iron storage proteins. Tricine SDS-PAGE was used to resolve low molecular weight proteins. Observed changes in two proteins were analyzed by Western blots to identify proteins involved.

Soluble iron $\left(\mathrm{FeCl}_{3}\right)$, chelated iron (FeEDTA) and iron in the form of Saharan dust were added to incubation flasks containing Trichodesmium. SDS-PAGE and Western blots were used to determine the effect of iron on the iron protein of nitrogenase and 
compare these changes to natural changes in this protein that occur on a diel basis.

Acetylene reduction (AR) assay was used to determine the effect of iron in different forms on the activity of nitrogenase. The combination of SDS-PAGE and AR allows a comparison of structural changes in the iron protein of nitrogenase and the activity of the nitrogenase enzyme complex.

\section{Field collection}

Trichodesmium colonies were collected in the eastern Caribbean Sea January and April 1990, January and September 1991 and 1992 (Appendix II). A comparative study was done in the Sargasso Sea near Bermuda in April and May 1991 at the Bermuda Atlantic Time-series site $\left(31^{\circ} 50^{\prime} \mathrm{N}, 64^{\circ} 10^{\prime} \mathrm{W}\right)$ and at the Hydrostation S site $\left(32^{\circ} 10^{\prime} \mathrm{N}, 64^{\circ} 30^{\prime} \mathrm{W}\right)$. Mainly Trichodesmium thiebautii were collected in these experiments as great care was used to avoid collecting Trichodesmium erythraea. However, other species may have been collected. The speciation of Trichodesmium colonies based on ultrastructure is currently being investigated (Bergman, pers. com.). The experiments in the Caribbean Sea were performed aboard the R/V Columbus Iselin. Trichodesmium colonies were collected from 10 meter depths using a plankton net $1 \mathrm{~m}$ in diameter and $202 \mu \mathrm{m}$ in mesh size. To dilute the sample, the content of a plankton tow was poured into a bucket containing surface seawater. Trichodesmium colonies were plucked from the plankton tow by using a plastic inoculating loop and placed in plastic beakers with 
fresh GF/F filtered surface seawater. The GF/F filtered seawater was used as a rinse to isolate the colonies from grazers and assorted associated organisms. Only tuft forms were collected for experiments in the Caribbean Sea. Puff forms were collected only for comparison purposes using SDS-PAGE. Experiments in the Sargasso Sea were performed on shore at the Bermuda Biological Station for Research and onboard the R/V Weatherbird II. Trichodesmium colonies were collected from the surface waters $(1-5 \mathrm{~m})$ using a plankton net $1 \mathrm{~m}$ in diameter $330 \mu \mathrm{m}$ in mesh size. Mainly puff forms were collected in Bermudian waters, although some tufts were collected separately when available for a comparison.

Protein and iron content were analyzed over diel periods consisting of 18, 24 and 42 hours in April 1990 and February 1991 in the eastern Caribbean Sea (Appendix II). In January 1990 daily iron content at approximately 1300 hours was analyzed on four different days. On April 11-12, 1990, colonies were collected approximately every $7 \mathrm{hr}$ over a $24 \mathrm{hr}$ period west of St. Kitts. On April 16, 1990, colonies were collected every $6 \mathrm{hr}$ over an $18 \mathrm{hr}$ period west of Saba and the British Virgin Islands On February 6-7, 1991, colonies were collected every $6 \mathrm{hr}$ for a $42 \mathrm{hr}$ period west of Guadeloupe. On February 12-13, 1991, colonies were collected west of St Croix and St. Thomas every $6 \mathrm{hr}$ for a $24 \mathrm{hr}$ period.

\section{Bicinchoninic Acid Protein Assay Reagent for Total Cellular Protein}

The Bicinchoninic Acid (BCA) Reagent available from Pierce Chemical was used for the spectrophotometric determination of 
protein in colonies of Trichodesmium. The assay was performed as described in Hutchins (1989) for Trichodesmium colonies and the assay itself as described by the manufacturer for the "Enhanced Protocol". The BCA reagent creates a complex with protein and $\mathrm{Cu}^{2+}$ (the biuret reaction) that results in a colorimetric detection for reduced copper ions $\left(\mathrm{Cu}^{1+}\right)$. This reagent is compatible with biochemical reagents such as sodium dodecyl sulfate which is required in this assay to solubilize cellular and membrane bound protein. The Enhanced Protocol has a protein concentration range of $5-250 \mu \mathrm{g} / \mathrm{ml}$. Of the three protocols given by the manufacturer, the Enhanced protocol has a greater color stability.

Either 25 or 15 colonies, depending on abundance, were placed on a GF/A filter and stored at $-20^{\circ} \mathrm{C}$ in $15 \mathrm{ml}$ polypropylene centrifuge tubes. The diel samples were collected every six hours for 24 hours or 48 hours during April 1990 and February 1991. Prior to analysis, the filters were taken from the centrifuge tubes and placed in a Wheaton glass mortar. The colonies and filter were ground with a teflon grinding pestle to solubilize proteins in $2 \mathrm{ml}$ of $1 \% \operatorname{SDS}(\mathrm{w} / \mathrm{v})$. After grinding to a foam and ensuring that entire filter was ground, the sample was poured back into the original $15 \mathrm{ml}$ centrifuge tube and one additional $\mathrm{ml}$ of $1 \%$ SDS was used to rinse the mortar, bringing the sample volume to a total of $3 \mathrm{ml}$. The sample solution was then placed in the refrigerator overnight to ensure complete solubilization of cellular protein. After complete solubilization, the samples were spun at $12,000 \mathrm{rpm}$ in a desktop centrifuge. An aliquot of $100 \mu \mathrm{l}$ of the sample supernatant was added to $2 \mathrm{ml}$ of 
BCA Working Reagent prepared as described in the Pierce BCA Assay Protocol. The enhanced protocol requires an incubation at $60^{\circ} \mathrm{C}$ for 30 minutes before cooling to room temperature. The absorbance of the purple reaction product was read at $562 \mathrm{~nm}$ wavelength on a spectrophotometer. The protein concentration of the sample is determined from a standard curve using purified bovine serum albumin supplied in the Pierce BCA Protein Assay Reagent kit. Because of the dilution factor caused by the addition of three $\mathrm{ml}$ of $1 \%$ SDS, the value of the sample obtained from the standard curve is multiplied by a factor of three.

\section{Acid Leachable Iron by the Ferrozine Assay}

Ferrozine, a spectrophotometric reagent for iron, was used to determine acid leachable iron content in field collected Trichodesmium colonies. The assay was preformed as described by Hutchins (1989) for Trichodesmium colonies. The assay is a modification of Stookey (1970) and Gibbs (1979). Ferrozine, a disodium salt, is a chelator that reacts selectively with divalent iron to form a stable magenta complex species with a maximum absorbance at $562 \mathrm{~nm}$ (Stookey 1970). A 10\% hydroxylamine hydrochloride solution $(\mathrm{w} / \mathrm{v})$ is used as a reducing agent to yield total dissolved cellular iron. All assay tubes were acid-cleaned overnight and rinsed six times in nanopure distilled water.

Daily variation of acid leachable iron content was analyzed in January 1990 (200 colonies per sample) at approximately 1300 hours on four different days. Samples for the diel experiments were 
collected every six hours for 24 or 48 hours during April 1990 (100 colonies per sample) and February 1991 (50 colonies per sample). Trichodesmium colonies were placed in $2 \mathrm{ml} 1 \mathrm{~N}$ hydrochloric acid $(\mathrm{HCl})$ in a $15 \mathrm{ml}$ polypropylene tube using an acid-cleaned plastic inoculating loop. Diel samples were collected every six hours for 24 and 48 hours. The $15 \mathrm{ml}$ polypropylene tubes containing the samples were placed in a VWR heating block for 24 hours at $60^{\circ} \mathrm{C}$. After leaching samples for 24 hours in the heating block, the sample were centrifuged in a desktop centrifuge for five minutes at 14,000 rpm. One $\mathrm{ml}$ of supernatant (or standard) was mixed with $200 \mu \mathrm{l}$ each in the following order : buffer (400 $\mathrm{g}$ ammonium acetate and $350 \mathrm{ml} 58 \%$ ammonium hydroxide diluted to 1 liter), hydroxylamine hydrochloride $(10 \%)$, and ferrozine $(5.14 \mathrm{~g} / \mathrm{l})$. Samples were incubated for 10 minutes at room temperature and absorbance read at $562 \mathrm{~nm}$ wavelength using a spectrophotometer. The absorbance was plotted against the standard curve and the calculated values were multiplied by a factor of 2 as these values represent half of the iron in the original $2 \mathrm{ml}$ leaching solution. Standards solutions $(0,1$, $5,10,30$, and $50 \mu \mathrm{M}$ ) were prepared from $18 \mathrm{mM}$ stock of ferric chloride in $1 \mathrm{~N} \mathrm{HCl}$. Absorbance at $0 \mu \mathrm{M}$ was used as an assay blank and subtracted from the other standards. A blank of $1 \mathrm{~N} \mathrm{HCl}$ was run with every set of sample replicates and subtracted from the absorbance value of the sample in order to eliminate trace background contamination of iron.

An additional experiment was performed to rinse extracellular iron from the colonies and determine a more accurate 
amount of intercellular iron in Trichodesmium colonies. After handling the colonies as described above, the colonies were rinsed in a Chelex (CHELEX 100, BIO-RAD) and GF/F filtered sea water (CFSW) rinse and an ascorbate rinse $(1 \mathrm{M})$ were used to exclude extracellular iron. Fifty colonies were plucked from a plankton net tow as previously described and then placed in chelexed filtered sea water as a quick rinse before being transfered to $1 \mathrm{~N} \mathrm{HCl}$. Another 50 colonies were placed into chelexed filtered seawater that contained $1 \mathrm{M}$ ascorbate before being placed in $1 \mathrm{~N} \mathrm{HCl}$. There were two replicates for each condition. Fifty additional colonies were placed in nitric acid ( $\left.\mathrm{HNO}_{3}\right)$ without being rinsed in order to observe the leaching capability of $\mathrm{HNO}_{3}$ compared to $\mathrm{HCl}$ routinely used in the Ferrozine assay. Colonies were also assayed for protein content in the rinse experiments to determine if a loss of biomass occured during these additional treatments.

\section{Development of the SDS-PAGE Method}

The high proteolytic activity in the colonies makes protein separation by gel electrophoresis difficult. A method using liquid nitrogen and high resolution gels on a Mini-Protean II gel apparatus (BIO-RAD) has been devised to overcome this difficulty with good results.

Trichodesmium colonies used for the development of this method were collected in the eastern Caribbean Sea, mainly in Exuma Sound, while aboard the University of Miami research vessel Columbus Iselin January 1990. Plankton tows were retrieved from 
depths of 10-15 m. Once this method was developed, it was used on all other cruises. The SDS-PAGE techniques used were modifications from Laemmli (1970).

First attempts at sample preparation involved using a 0.05 ionic strength tris-HCL buffer (for details see Appendix 1). A type HA $0.45 \mu \mathrm{m}$ Millipore filter $(\mathrm{HA}=\mathrm{a}$ mixture of cellulose acetate and cellulose nitrate) attached to a $12 \mathrm{cc}$ syringe fitted with a Millipore Swinex-13 filter rig clamped vertically on a ring stand was required to remove salt water from the sample (Figure 2). Gentle suction was employed to extract seawater from the sample on the filter. Seawater interferes with the matrix of the polyacrylamide gel; its removal gives better resolution and high molecular weight bands were detected.

In the second attempt (see Appendix 1) the 0.05 I buffer step was eliminated and the SDS sample buffer was added directly to samples on the Millipore filters. However, there was no improvement observed in the gel using this modification.

A $12 \%$ polyacrylamide gel method was used that has a $2 \%$ bis-acrylamide stock solution instead of $0.8 \%$ and stock solutions of $10 \%$ SDS and $50 \%$ glycerol were added to the unpolymerized gel solution (Zehr pers. comm.). The $12 \%$ gels were run at $200 \mathrm{~V}$ which over-heated. Some low molecular weight bands were detected but there was still poor resolution (smearing) and there were no high molecular weight bands detected. The samples were stored at $-20 \circ \mathrm{C}$ after preparation and then thawed prior to gel loading. 


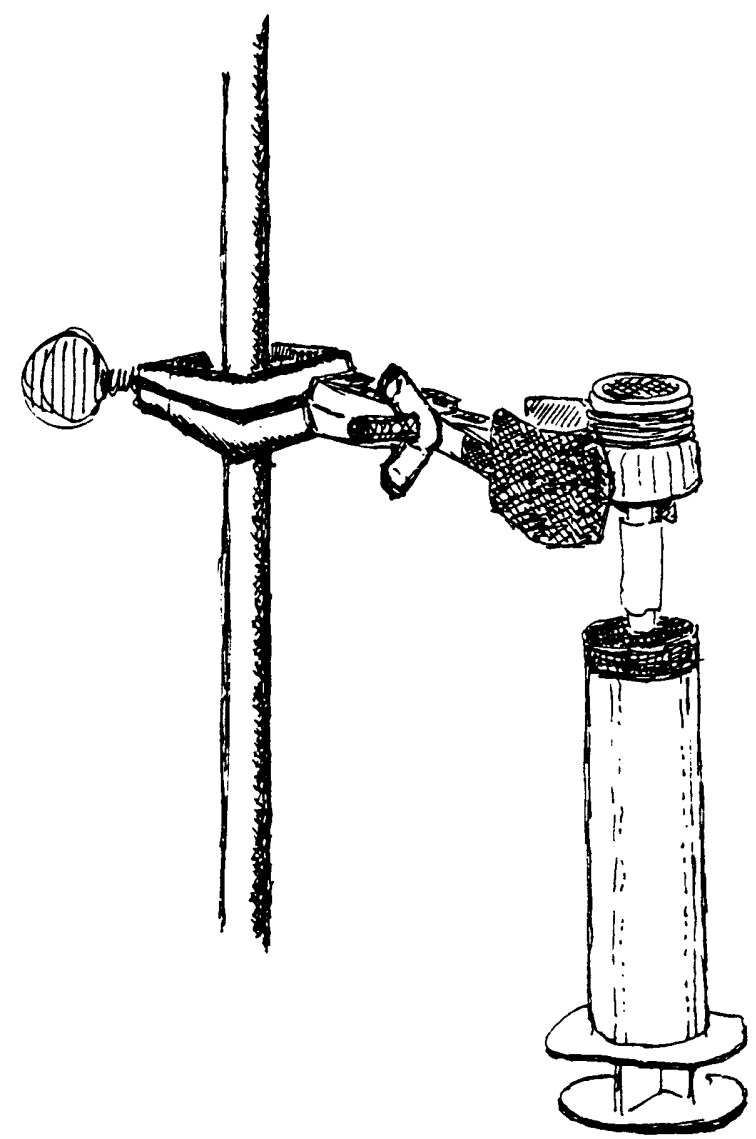

Figure 2. Filtration apparatus. 
The following method was tried with good results; sample preparation requires quickly placing colonies onto a Millipore filter with gentle suction from the syringe to remove salt water. Twenty Trichodesmium colonies on the Millipore filter were placed in a 1.5 ml Eppendorf tube, frozen in liquid nitrogen and then stored at -20 ${ }^{\circ} \mathrm{C}$ until SDS-PAGE was performed. The SDS sample buffer used for protein solubilization contained PMSF and beta-mercaptoethanol prior to use (Zehr 1990). A 20:40 dilution (20 colonies to $40 \mu \mathrm{l}$ of buffer) was used and samples were boiled in water and centrifuged in an Eppendorf Microfuge at 8,000 x $g$. Samples were used immediately after SDS sample buffer. Once SDS sample buffer is added, the samples should be kept at room temperature and never refrozen. Trichodesmium are so full of proteases that when frozen with SDS, the SDS precipitates upon thawing and allows for proteolytic activity (Zehr pers. com.). At room temperature the SDS remains coated around the proteins preventing proteolysis. The $12 \%$ gel system using glycerol in the gel matrix gives high resolution in the low molecular weight range. This gel system can not tolerate high voltage settings. The solutions used in this method are listed in appendix.

A modification in the preparation of SDS sample buffer was made. PMSF was deleted from stock solution because it did not solubilize well and instead was added later when the stock sample buffer was diluted for sample solubilization to a final concentration of $1 \mu \mathrm{M}$. Loading volumes were $10 \mu \mathrm{l}$ per well, electrode buffer was diluted 1:5 from a $5 x$ stock (Appendix I) and running conditions 
were $150 \mathrm{~V}$ for two gels for approximately 1.5 hours. The gels were stained in coomassie blue and destained with $10 \%$ acetic acid. The results of this method produced good separation of proteins with multiple bands and high resolution.

\section{Low Molecular Weight SDS-PAGE}

In order to detect low molecular weight bands with greater resolution, Tricine-SDS-PAGE technique was used to separate proteins in the range from 1 to $100 \mathrm{kDa}$ (Schagger and von Jagow 1987). This gel system was used to detect phycoerythrin (18kDa) for Western blots. This method was followed as published for a $16.5 \%$ $\mathrm{T}, 6 \% \mathrm{C}$ separating gel, a $10 \% \mathrm{~T}, 3 \% \mathrm{C}$ spacer gel and a $4 \% \mathrm{~T}, 3 \% \mathrm{C}$ stacking gel ( $\mathrm{C}$ denotes the percentage concentration of the crosslinker relative to the total concentration $\mathrm{T}$ ). Samples were treated as described above for SDS-PAGE with the exception that running conditions of this gel system requires approximately 8 hours with a $30 \mathrm{~mA}$ constant.

Iron and Dust Incubations for SDS-PAGE

Three incubation flasks containing 40-50 colonies of Trichodesmium thiebautii were incubated up to 24 hours in $200 \mathrm{ml}$ of GF/F filtered sea water (FSW) consisting of a control (FSW), $1.8 \times$ $10^{-8} \mathrm{M} \mathrm{FeCl}_{3}$ iron, and an addition of $10 \mathrm{mg}$ of Saharan dust to the third culture. The amount of iron contained in the dust was estimated by assuming that $5 \%$ of the dust is iron (Rueter pers. comm.) and $10 \%$ of the iron is soluble (Moore et al. 1984). Ten $\mathrm{mg}$ of 
dust added to $200 \mathrm{ml}$ of filtered seawater (FSW) would be approximately $4.48 \mu \mathrm{M}$ Fe.

Twenty colonies were dissolved in $40 \mu \mathrm{l}$ of SDS protein solubilization buffer as described above. The samples were run on a $212 \%$ gels at $150 \mathrm{v}$ for 1 hour. One of the gels was stained with coomassie to observe protein resolution. In order to detect iron containing proteins, the other gel was stained with prussian blue as described in Gaal et al. (1980). The more sensitive bathophenanthroline reagent was also used as described in Uriel and Chuilon (1965) to stain iron proteins in the gel. An equine ferritin standard $(100 \mathrm{mg} / \mathrm{ml})$ was used with the bathophenanthroline reagent.

\section{Western blot immunoassays}

Trichodesmium colonies collected were subjected to sodium dodecyl sulfate polyacrylamide gel electrophoresis (SDS-PAGE) and Western blotting for immunoassays (BIO-RAD Immuno-Blot kit). The Immuno-Blot Assay Kit used was goat anti-rabbit horse radish peroxidase conjugate (GAR HRP) and was obtained from BIO-RAD. The method was followed as directed in the instruction manual included in the kit. The primary antiserum used is rabbit antidinitrogenase reductase from Rhodospirillum rubrum (gift from Dr. Jon Zehr and Dr. Birgitta Bergman) and rabbit anti-phycoerythrin from Phormidium perscicinum (gift from Dr. Birgitta Bergman). Primary antibodies against dinitrogenase reductase were used at a dilution of 1:5000 and against phycoerythrin at 1:500 (primary 
antisera:buffer). The secondary antibody was supplied in the kit and used as instructed in the manual at a 1:3,000 dilution. Colonies were collected when fixing nitrogen during the day and when not fixing nitrogen at night and assayed to determine the presence or absence of the modified form of dinitrogenase reductase. Colonies were also collected to detect any changes in phycoerythrin subunits on a diel time scale. Colonies for iron nutrition experiments were placed in $200 \mathrm{ml}$ of filtered sea water in a $250 \mathrm{ml}$ acid washed polycarbonate erlenmeyer flasks. Three conditions were used: control (no iron added), soluble iron $\left(1.8 \times 10^{-8} \mathrm{FeCl}_{3}\right.$ in $\left.1 \mathrm{~N} \mathrm{HCl}\right)$ and Saharan dust (10 $\mathrm{mg}$ ). Colonies were collected in the morning hours, incubated throughout the day and harvested in the evening after "turn-off" of nitrogenase.

\section{Acetylene reduction assay}

Acetylene was used as a substrate for nitrogenase. This assay is based on the 2 electron reduction of acetylene to ethylene. The product ethylene was measured on a Mini Schimadzu Gas Chromatograph with a flame ionization detector fitted with a $2 \mathrm{~m} \mathrm{x}$ 1/8" stainless steel column packed with Poropak R, 100/120 mesh. Nitrogen is the carrier gas and hydrogen and compressed air are used for the flame. Colonies were assayed for acetylene reduction during the day-time because nitrogen fixation ceases after late afternoon (Capone et al. 1990). The method was followed as described in Capone (1993) except that $0.5 \mathrm{ml}$ acetylene was used instead of $1 \mathrm{ml}$. Ten colonies were placed in $5 \mathrm{ml}$ of $\mathrm{GF} / \mathrm{F}$ filtered 
seawater in $9 \mathrm{ml}$ serum vials. The serum vials were capped with red silicone rubber septa and crimp-sealed with aluminum seals. Acetylene was injected into serum vial headspace and $100 \mu \mathrm{l}$ subsamples were removed from the headspace for analysis of ethylene. One hundred $\mu l$ of an ethylene standard (94.3 ppm) was injected at each time point.

For acetylene reduction assays, Trichodesmium colonies were incubated with $\mathrm{FeCl}_{3}$ and dust as described for SDS-PAGE with the addition of a fourth flask containing $10^{-8} \mathrm{M}$ FeEDTA. Colonies were either incubated for several hours before acetylene was added or the iron solutions were added directly to the acetylene reduction vial. Colonies were also incubated in $1.8 \times 10^{-7} \mathrm{FeCl}_{3}$ and $10^{-7} \mathrm{M}$ FeEDTA and $10^{-6} \mathrm{M}$ EDTA in later experiments for comparison. 


\section{RESULTS}

\section{Protein and Iron Content}

Protein content in Trichodesmium colonies in April 1990, did not change significantly over a diel period (Figure 3). Considerable variation in samples was observed on April 11th where in one time point samples ranged from 12 to $25 \mu \mathrm{g}$ protein/colony. Although it is difficult to discern a diel change in protein content per colony because of this variability, colonies were collected at discrete locations for longer periods in time. In February 1991, colonies were collected over a 42 hour diel and showed a trend toward increased protein content in the later hours of the day (Figure 4). However, samples collected one week later did not show this trend over 24 hours. The lack of a diel change in samples may be due to variations in growth rate in different populations of Trichodesmium. Colonies undergoing rapid cell division would most likely show fluctuating protein levels.

On April 11-12, 1990, average protein content varied from 10.78 to $18.31 \mu \mathrm{g}$ per colony (Figure 3 ). The highest values occurred at 1400 and $1300 \mathrm{hr}$ (Figure 3). On April 16, 1990, average protein content varied from 10.68 to $14.99 \mu \mathrm{g}$ per colony and highest values occurred at 0400 and 1600 hours (Figure 3). During February 6-7, 1991, average protein content varied from 9.56 to $25.70 \mu \mathrm{g}$ per colony (Figure 4). In this experiment, there appeared to be a diel 


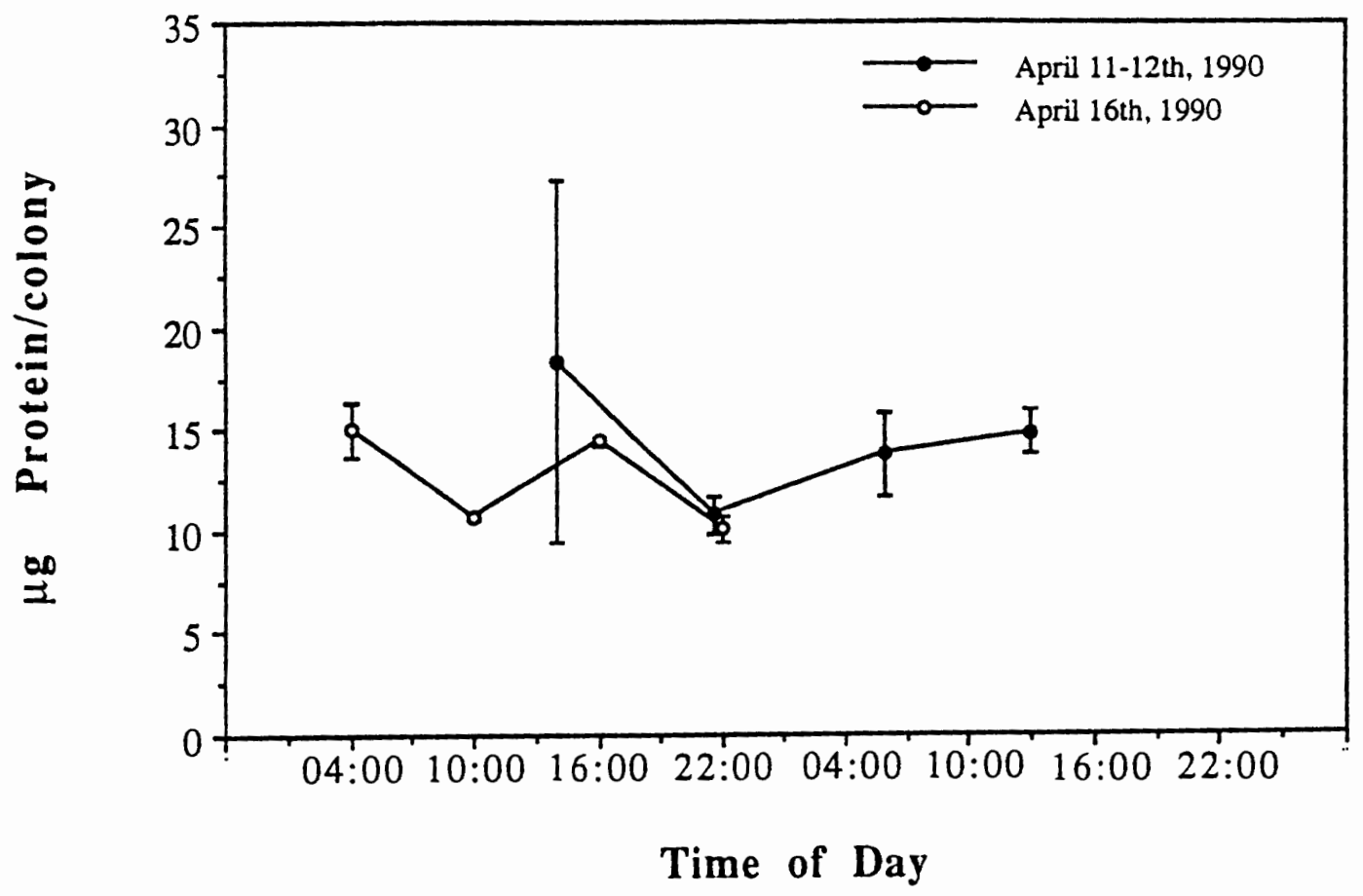

Figure 3. Protein content in Trichodesmium colonies as a function of time in April 1990. 


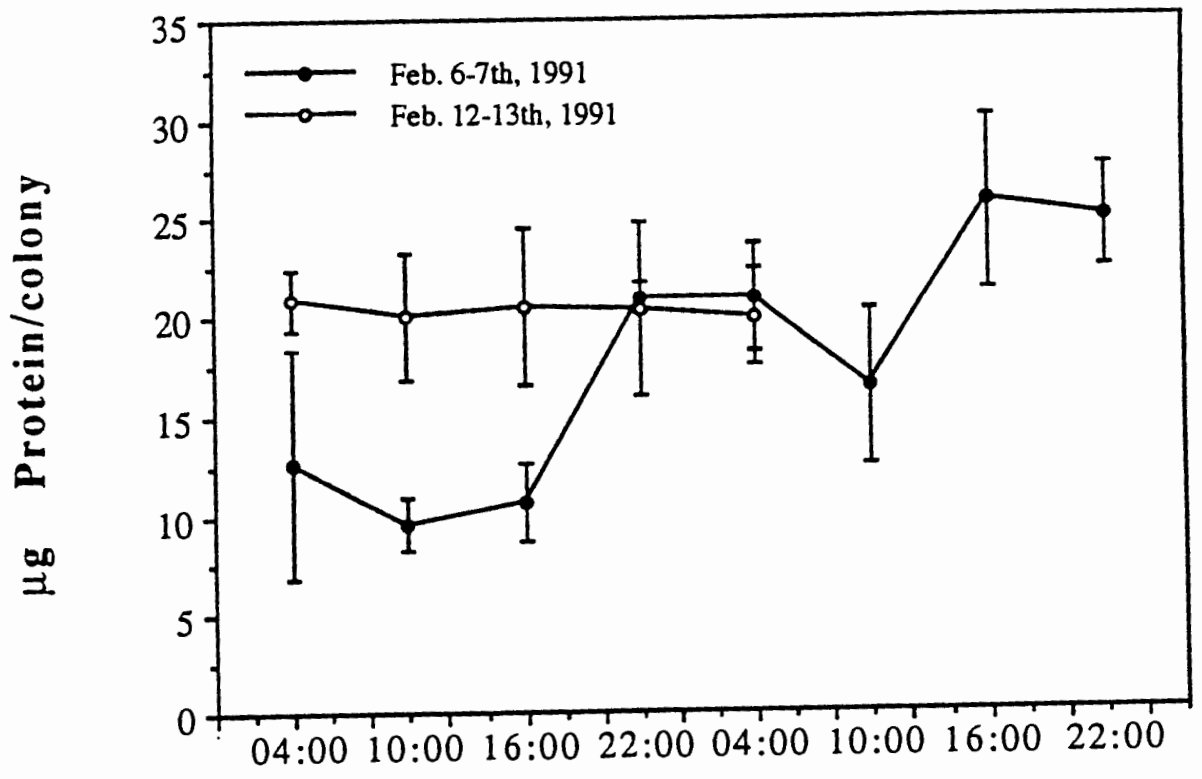

Time of day

Figure 4. Protein content in Trichodesmium colonies as a function of time in February 1991 from the Caribbean Sea. 
trend in protein content. During the first $24 \mathrm{hr}$, highest values occurred at 0400 hours. In the remaining $18 \mathrm{hr}$ of the experiment, highest values occurred 1600 and 2200 hours (Figure 4). On February 12-13, 1991, protein content remained more constant and varied from 19.94 to $20.85 \mu \mathrm{g}$ per colony (Figure 4).

Daily variation on January $10,13,17$, and 19 in acid leachable iron content was 0.25 to $0.45 \mathrm{nmol} \mathrm{Fe} /$ colony (Figure 5). Daily variation of iron content was plotted against nitrogenase activity measured as acetylene reduction and a correlation between iron content and nitrogenase activity was observed (Figure 6).

Data from April 11-12, 1990, show a variation in average acid leachable iron over a diel period to be 0.18 to $0.47 \mathrm{nmol} /$ colony with the highest value at 1300 hours. On April 16, 1990, average iron content varied from 0.34 to $0.82 \mathrm{nmol} \mathrm{Fe} /$ colony with the highest value occurring at 0400 hours (Figure 7). A sharp decrease in iron content was observed in February 1991. On February 6-7, iron content varied from 0.08 to $0.14 \mathrm{nmol} \mathrm{Fe/colony} \mathrm{(Figure} \mathrm{8).} \mathrm{On}$ February 12-13, 1991, iron content remained constant over the $24 \mathrm{hr}$ period and ranged from 0.10 to $0.15 \mathrm{nmol} \mathrm{Fe} /$ colony.

Acid leachable iron content was compared in different treatments as described in Methods and showed that $\mathrm{HCl}$ was superior to $\mathrm{HNO}_{3}$ as a leachate for cellular iron. Results from this experiment also show that colonies dipped in chelexed filtered seawater had a lower average iron content than colonies placed in filtered seawater only (Figure 9A). The addition of an ascorbate rinse did not result in even lower values of acid leachable iron 


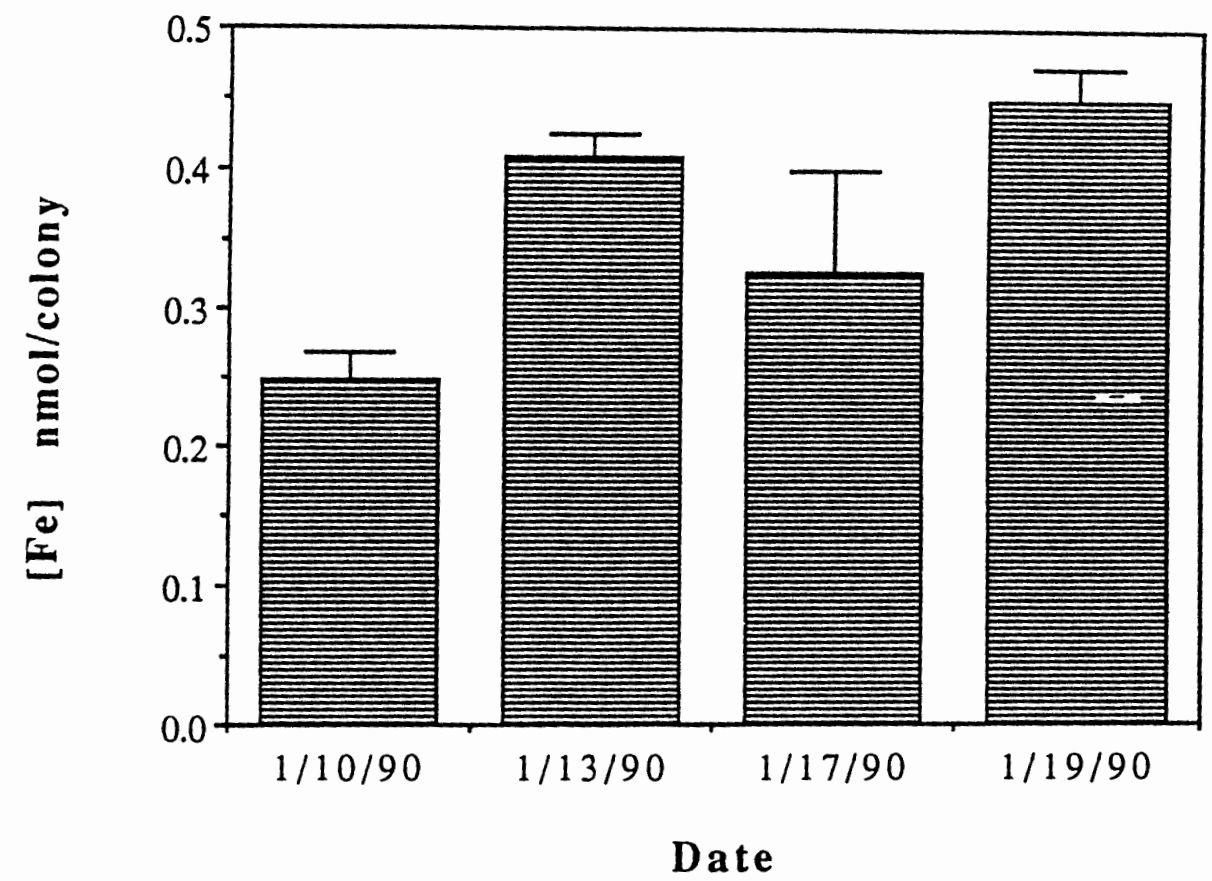

Figure 5. Daily variation of acid leachable iron content in Trichodesmium colonies in January 1990 from the Caribbean Sea. 


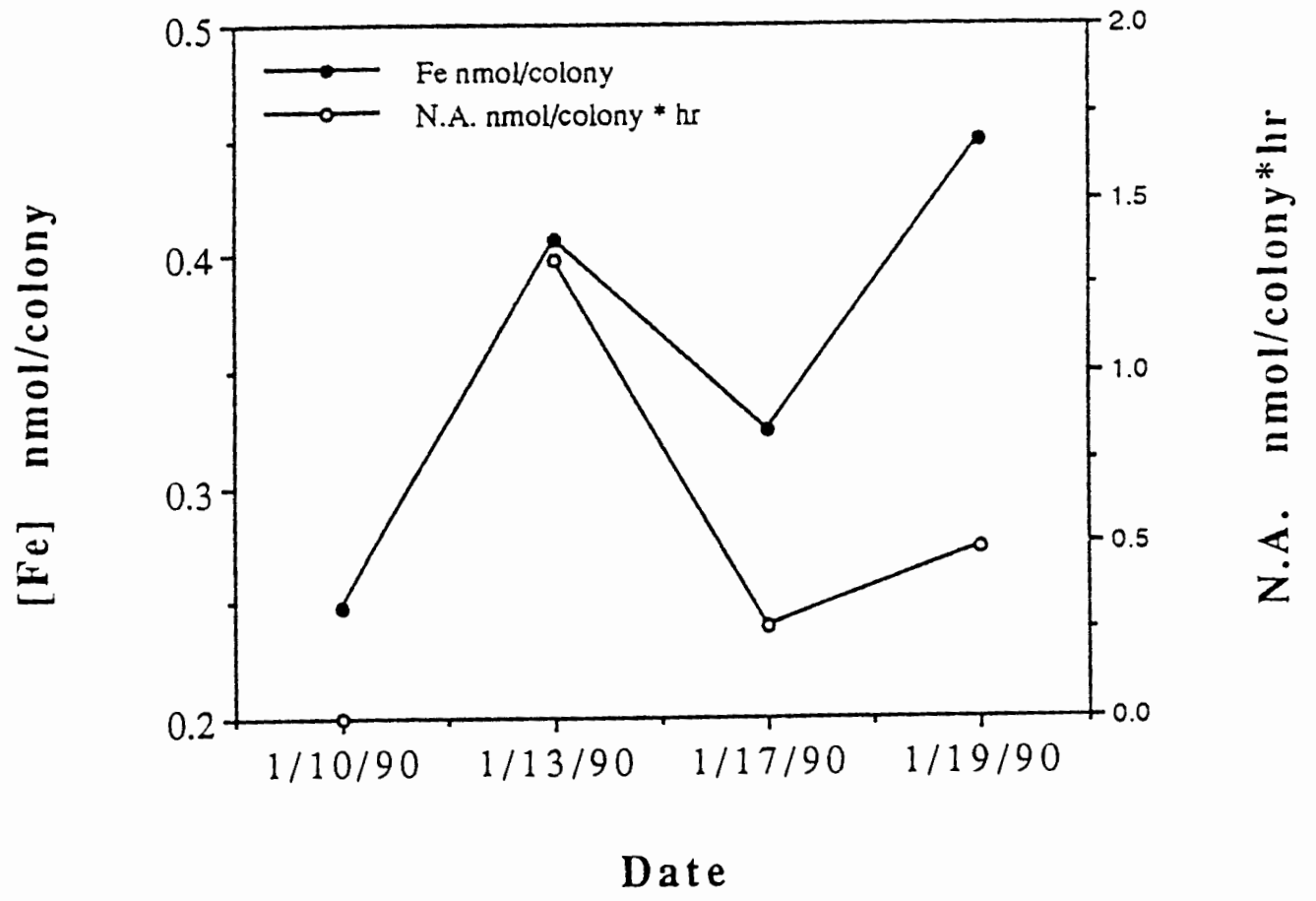

Figure 6. Daily nitrogenase activity (NA) and iron content in Trichodesmium colonies in January 1990. 


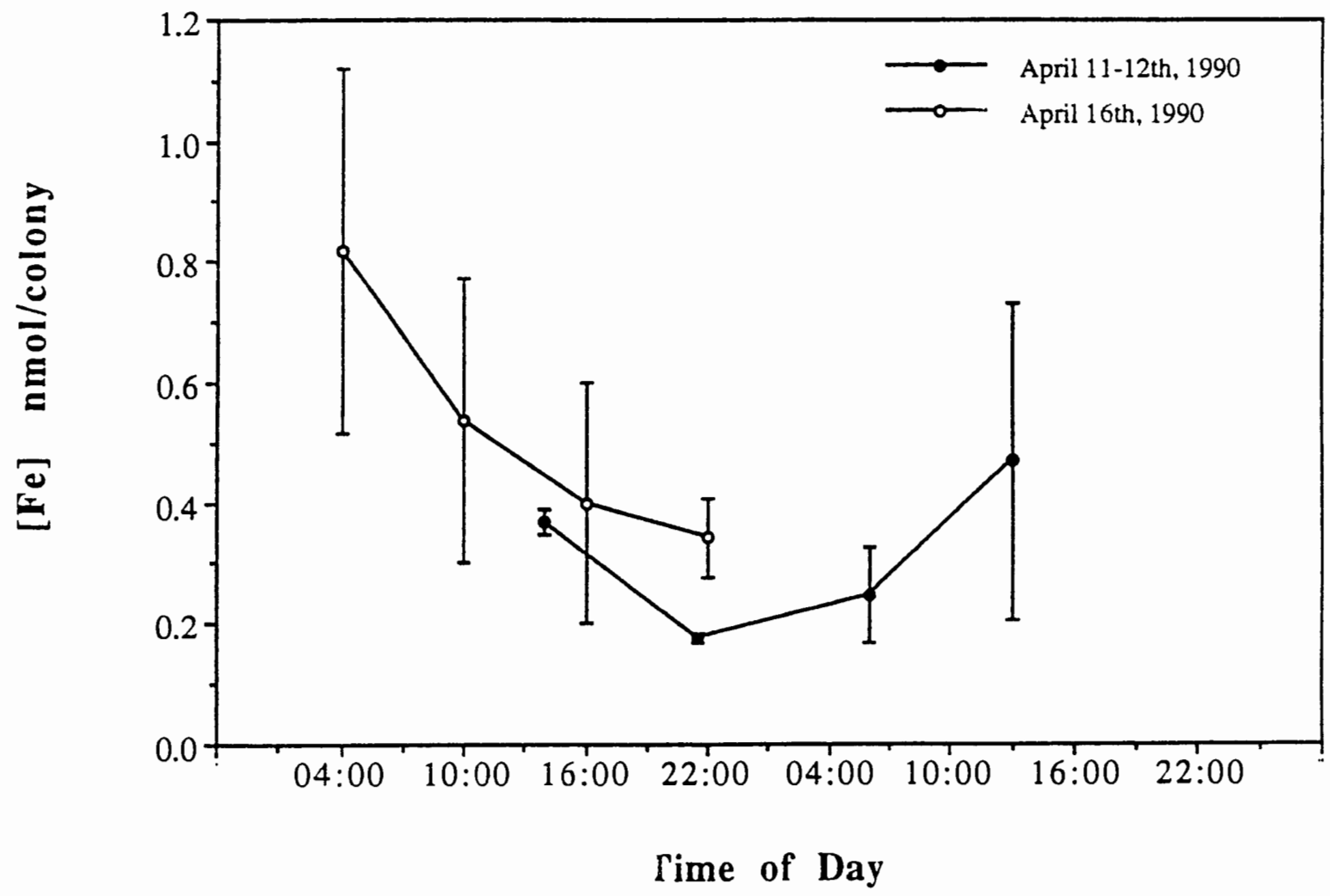

Figure 7. Acid leachable cellular iron content in Trichodesmium colonies as a function of time of the day in April 1990. 


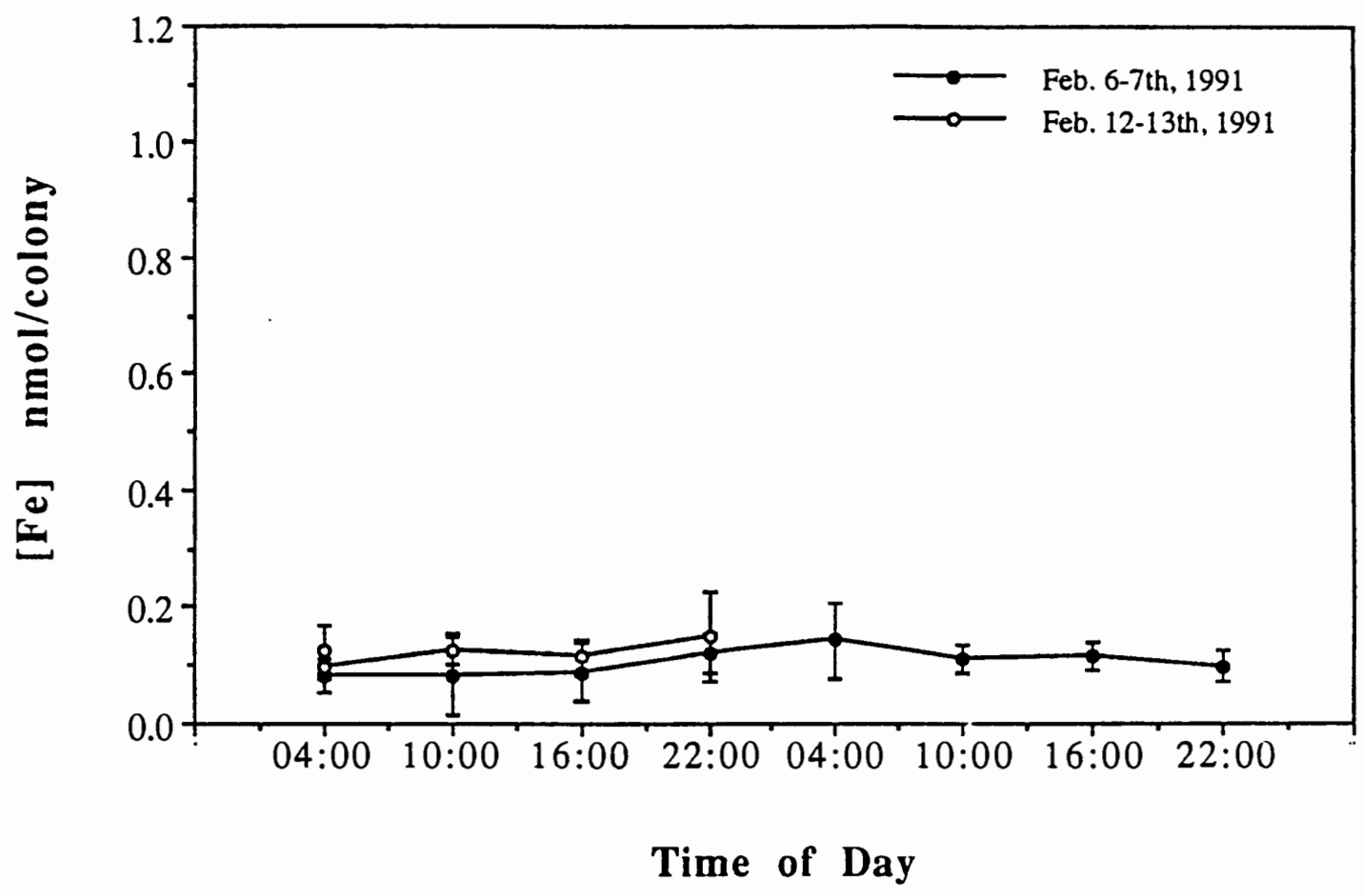

Figure 8. Acid leachable cellular iron content in Trichodesmium colonies as a function of time of the day in February 1991. 


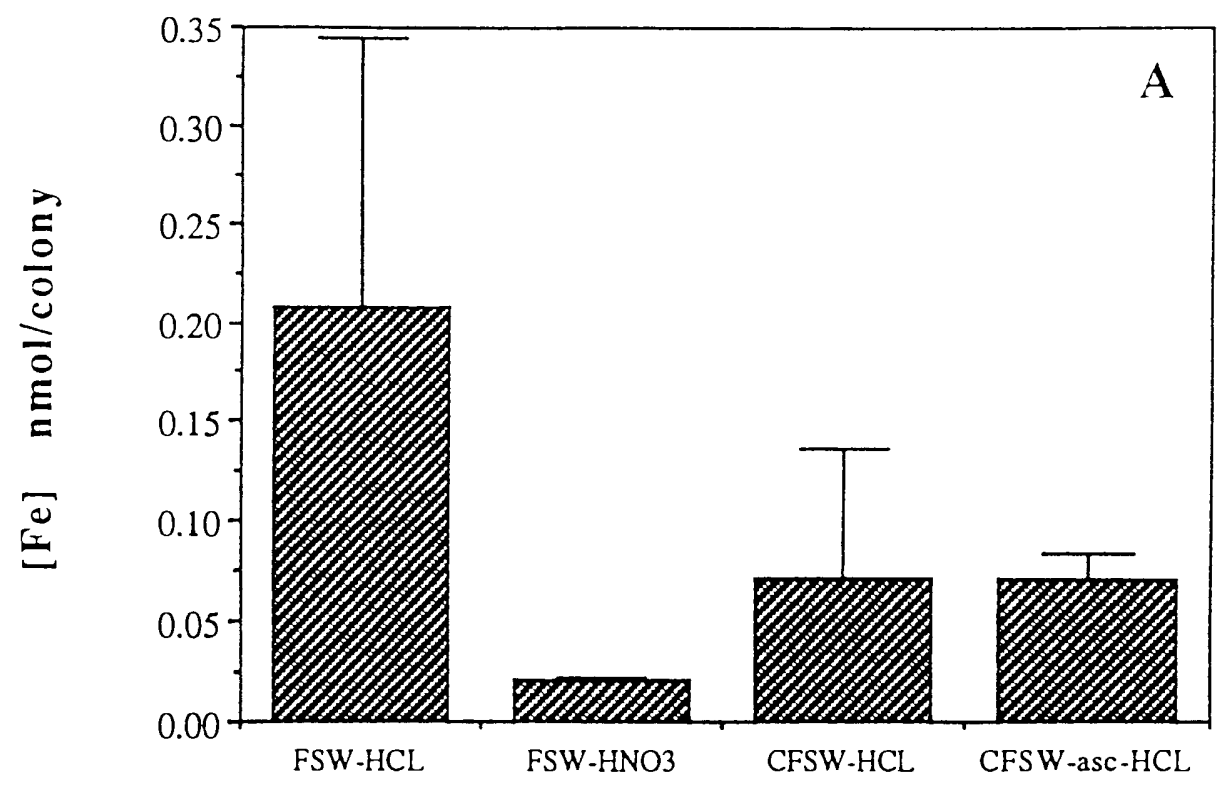

Pretreatment

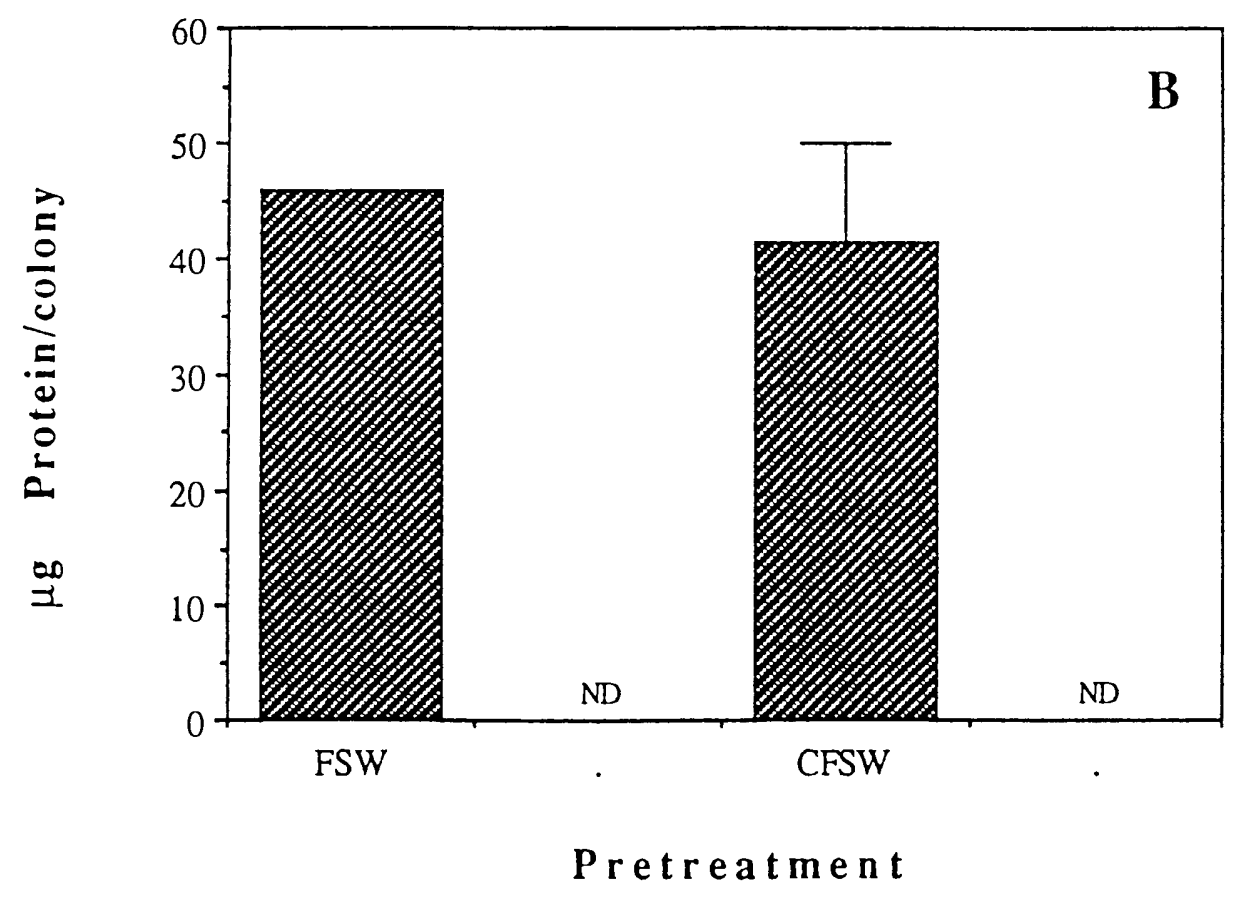

Figure 9. A: Pretreatment prior to the Ferrozine assay (A) and the protein content (B) in Trichodesmium colonies. FSW-HCl \& $\mathrm{FSW}=$ Filtered seawater rinse $+\mathrm{HCl}, \mathrm{FSW}-\mathrm{HNO} 3=\mathrm{FSW}$ rinse + $\mathrm{HNO}_{3}, \mathrm{CFSW}-\mathrm{HCl} \& \mathrm{CFSW}=\mathrm{FSW}$ rinse + chelated filtered seawater $(\mathrm{CFSW})+\mathrm{HCl}, \mathrm{CFSW}$-asc- $\mathrm{HCl}=\mathrm{FSW}$ rinse $+\mathrm{CFSW}+$ Ascorbic acid $+\mathrm{HCl}$. 
(Figure $9 \mathrm{~A}$ ). The results of this experiment indicate that the iron measured in this study is not attributed to extracellular iron. Colonies dipped in chelexed filtered seawater and chelexed filtered seawater with an ascorbate rinse were assayed for protein to determine if the extra handling would decrease the biomass. The analysis of protein/colony did not show a significant decrease in biomass in the Chelex rinse treatment (Figure 9 B). Results for the ascorbate treatment could not be obtained because ascorbate interferes with the protein assay. The Chelex rinse treatment may give a more accurate analysis due to reduction in the amount of ambient iron in seawater.

Due to the considerable variability in protein and iron content per colony, protein- $\mathrm{N}$ to iron ratios were calculated from the diel measurements. The mol to mol protein- $\mathrm{N}$ to iron ratios were plotted in Figure 10 which includes the boundaries of the upper and lower limits determined previously by Hutchins (1989) for Trichodesmium samples in the Caribbean Sea. The data indicate that at times, Trichodesmium populations have a higher limit of protein- $\mathrm{N}$ to iron ratio of up to 3000. The population in February 1991 had protein-N to iron ratios that exceeded 700 while the population in April 1990 had ratios that lie within the previous limits determined by Hutchins (1989).

\section{$\underline{\text { SDS-PAGE }}$}

The best results for SDS-PAGE required the use of a gentle 


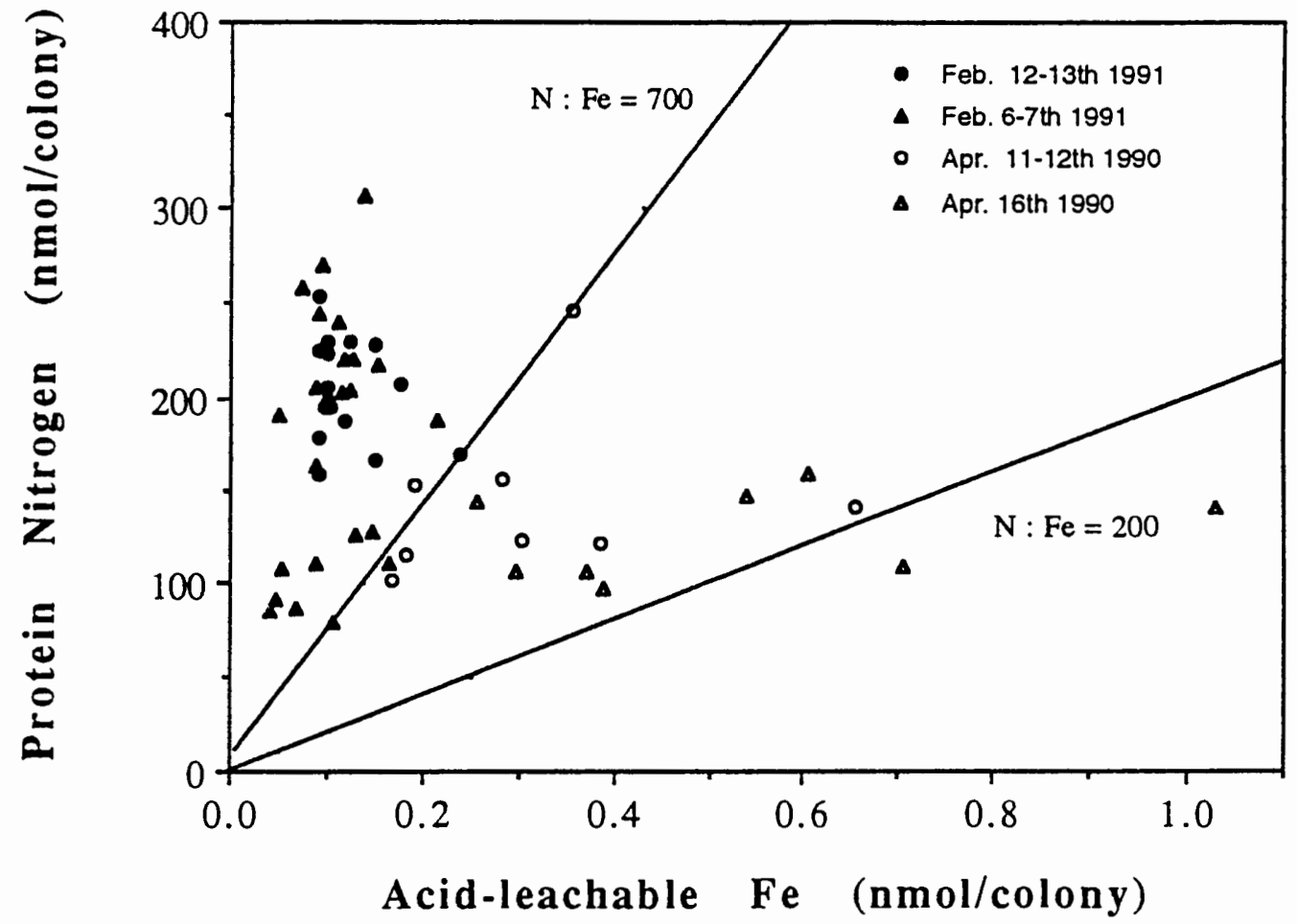

Figure 10. Protein nitrogen to iron ratios in Trichodesmium colonies from the Caribbean Sea. The N:Fe ratio limits (200 and 700) are taken from Hutchins (1989). 
filtration apparatus and millipore $\mathrm{HA}$ filter to remove salt from the colonies (Figure 11, lanes 7,8). Salt apparently interferes with the matrix of the gel or with sodium dodecyl sulfate and prevents complete solubilization of the protein subunits. It was also determined that a dilution of 20 colonies in $40 \mu \mathrm{l}$ of SDS protein solubilization buffer gave the best results (Figure 11, lanes 2-6) and a dilution of 20 colonies in $80 \mu$ l of SDS protein solubilization buffer was too dilute and did not result in high resolution (Figure 11, lane 9). Also observed on this gel is that puff and tuft colony morphologies have dissimilar protein bands, and that the puff form is more easily solubilized. This observation was observed in subsequent gels.

Changes in an unknown low molecular weight protein(s) between $17 \mathrm{kDa}$ and $27 \mathrm{kDa}$ standards were detected in diel samples (Figures 12, 13, 14). The proteins involved had an apparent molecular weight near 26 and $24 \mathrm{kDa}$. In Gel \#18 (Figure 12) the proteins appeared as two bands at 2200 hours and as a double band with a dominate upper band at 1000 and 1600 hours and a single lower band at 0400 hours. Gel \#38 (Figure 13) showed the single upper band at 0400 and the double band at 1030 and 2200 hours. Gel \#39 (Figure 14) showed a double band at 0400 and a single upper band at 1000, 1600 and 2200 hours. A diel pattern of these changes in banding pattern was difficult to determine due to the inconsistency of the banding pattern, however a general trend was observed. The upper band appeared dominate during the daylight hours in Gel \#18 (Figure 12) and Gel \#39 (Figure 14) with a 


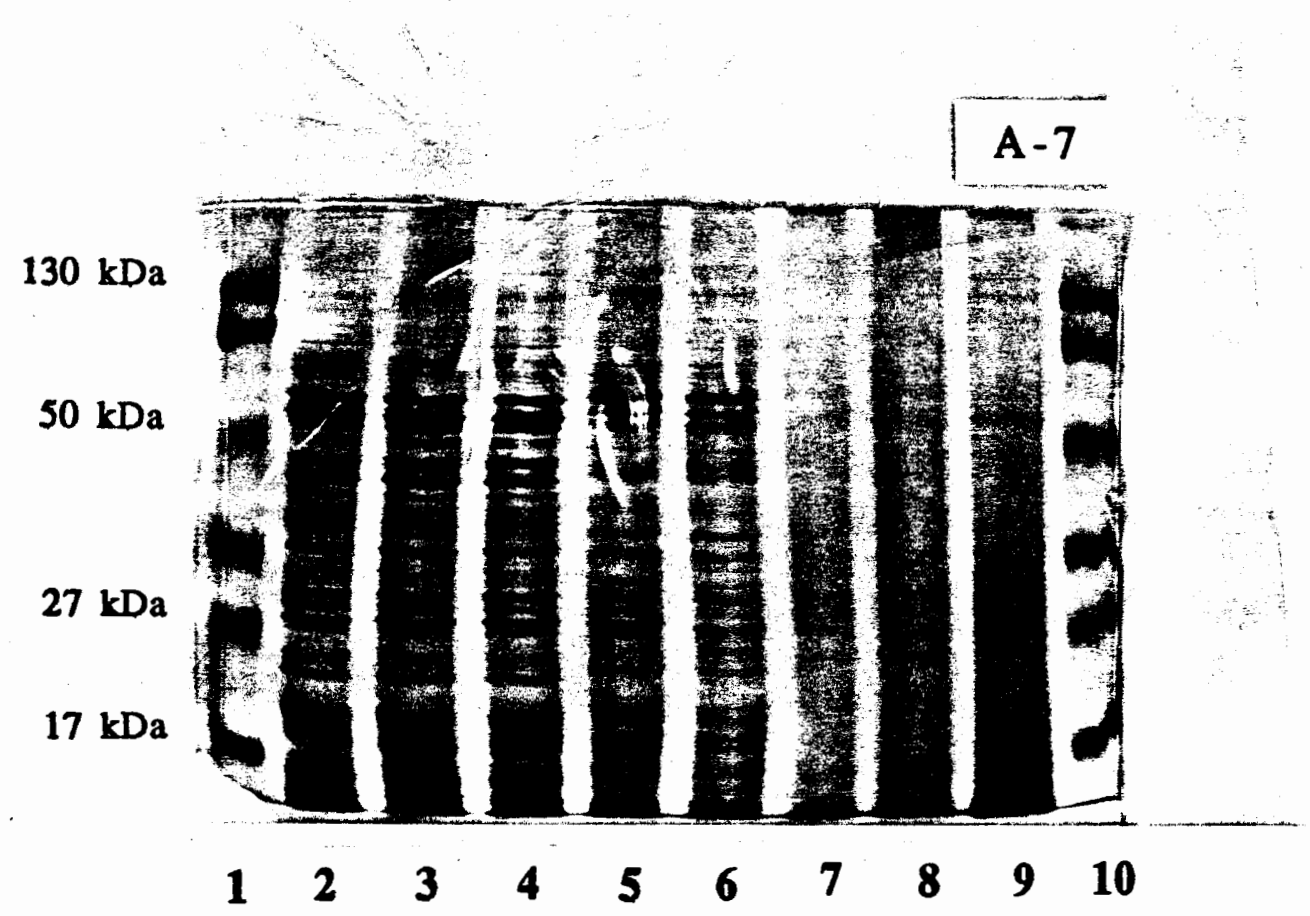

Figure 11. SDS-PAGE (Gel\#A-7) of Trichodesmium colonies in January 1990 from the Caribbean Sea. 1) molecular weight standard (MW std); 2-4) puffs; 5-6) tufts; 7-8) colonies collected without using the filtration technique to remove seawater; 9) overdilution of buffer relative to the amount of colonies present; 10) MW std. 


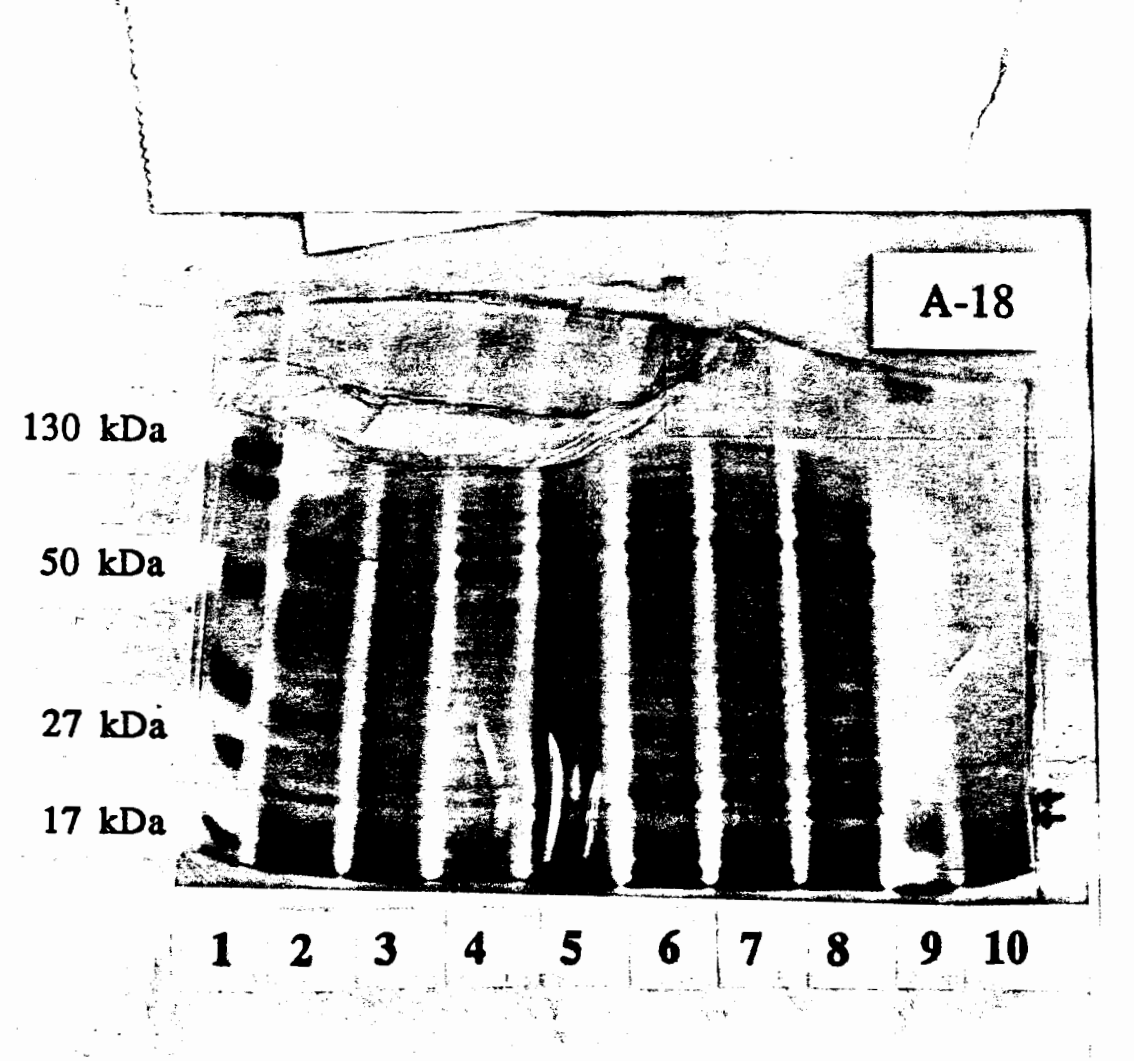

Figure 12. SDS-PAGE (Gel\#A-18) of Trichodesmium colonies in an iron addition and a diel experiment on 6 April, 1990 from the Caribbean Sea. 1) MW std̦; 2) control; 3) $\mathrm{FeCl}_{3}$ treatament; 4) dust addition; 5) $0400 \mathrm{~h}$; 6) $1000 \mathrm{~h}$; 7) $1600 \mathrm{~h}$; 8) $2200 \mathrm{~h}$; 9) horse ferritin; 10) overdilution of buffer relative to the amount of Trichodesmium colonies. 


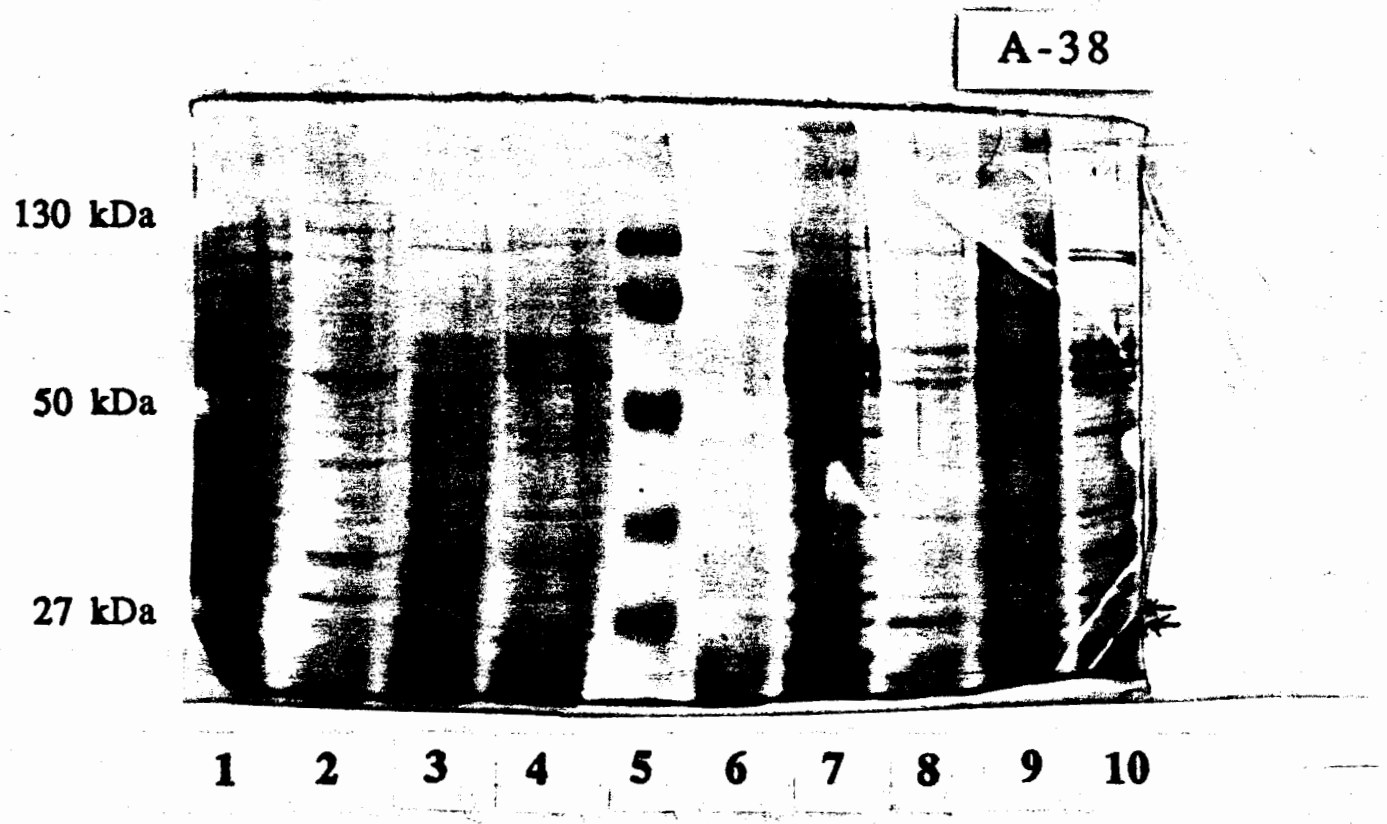

Figure 13. SDS-PAGE (Gel\#A-38) of Trichodesmium colonies in a diel and an iron addition experiment in February 1991 from the Caribbean Sea. 1) overloaded protein; 2) $0730 \mathrm{~h}$ (Feb. 6); 3) 0400 h (Feb. 7); 4) 1030 h (Feb. 6); 5) MW std; 6) $2200 \mathrm{~h}$ (Feb. 22); 7) Control with no iron addition;, 8) $\mathrm{FeCl}_{3}$ treatment; 9) dust addition; 10) $2200 \mathrm{~h}$ (Feb.7). 


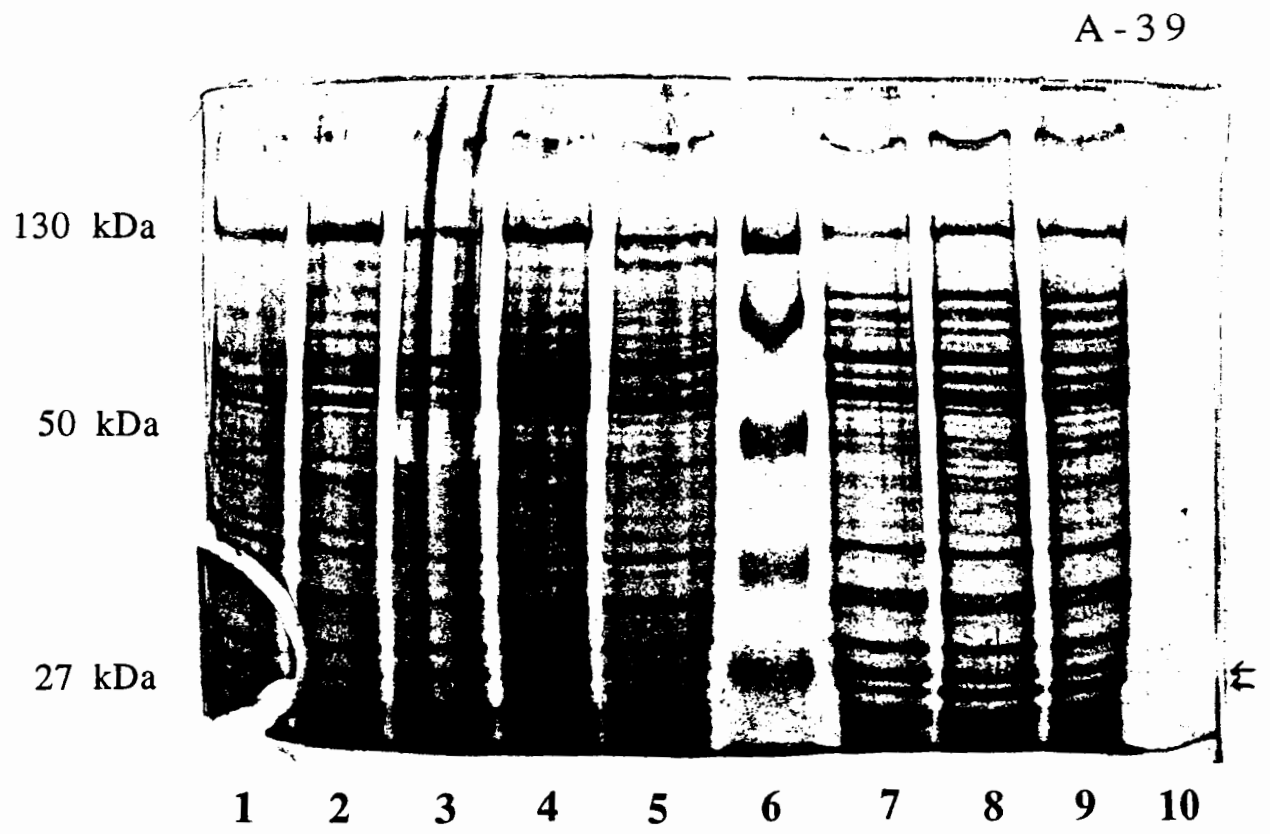

Figure 14. SDS-PAGE (Gel\#A-39) of Trichodesmium colonies in a diel and an iron addition experiment in February 1991 from the Caribbean Sea. 1) 0400 h (Feb. 12); 2) 1000 h (Feb. 12); 3) 1600 h (Feb. 12); 4) 2200 h (Feb. 12); 5) 0400 h (Feb. 13); 6) MW std; 7) control; 8) $\mathrm{FeCl}_{3}$ addition; 9) dust addition; 10) void. 
transition period in the dark hours to a double band. The resolution of the diel samples in Gel \#38 (Figure 13) was not as clear as the others and did not show this pattern.

Colonies were incubated in no iron as a control (C), $10^{-8} \mathrm{FeCl}_{3}$ (Fe) and in dust (D) for 8, 9 and 26 hours. Gel \#18 (Figure 12) shows an 8 hour incubation on April 16th 1990 that started at 0030 and stopped at 0830 hours. The control (lane 2) shows only the lower band and the samples incubated in iron and dust (lanes 3 and 4) show a double band (Figure 12). This was repeated in Gel \#38 (Figure 13) in a 9 hour incubation starting at 0030 and stopped at 0945 hours. The control (lane 7) and Fe (lane 8) showed a double band with a dominant upper band and the dust sample showed a strong double band (lane 9) (Figure 13). A longer incubation of 26 hours on February 13th to 14th was started at 0615 and stopped at 0900 hours the next day is shown in Gel \#39 (Figure 14). The control has a double band with a dominant upper band and the iron and dust samples show a double band with a dominant lower band (Figure 14).

In order to determine if the unidentified protein was involved in iron storage proteins such as a ferritin-like molecule, gels were stained first with the Prussian blue reaction. Prussian blue did not stain any proteins on the gels. The more sensitive bathophenanthroline stain was used on additional gels containing concentrated dilutions of colonies and a horse ferritin standard resulting in staining only of horse ferritin (see Figure 12 for example of horse ferritin). 
The unidentified protein lies in the same molecular weight region as phycoerythrin. A low molecular weight (LMW) gel was run and resulted in better resolution of low molecular weight proteins including phycoerythrin.

\section{Western Blot Immunoassays}

The blot \#B38 (Figure 15) and LMW gels were probed for phycoerythrin and resulted in a large band at approximately $18 \mathrm{kDa}$. Although the molecular weight of the unidentified protein is close to that of phycoerythrin, immunoassay results revealed that it did not cross react with phycoerythrin.

A diel change in the iron protein of nitrogenase was observed in the Caribbean Sea population that corresponds to the activity of the enzyme. Due to the uncertainty of using SDS-PAGE for the detection of molecular weight changes in proteins, caution is used with the term "modification." The iron protein of nitrogenase has an apparent change in molecular weight that may be a result of covalent modification of one or both of the identical subunits. For convenience of descriptional detail in this thesis, the term "modification" will be used however, the mechanism of modification is yet unknown in Trichodesmium. The higher molecular weight form is an apparently modified form and is inactive. The lower molecular weight form is unmodified and active. This is more clearly shown in Figure 16.

Results of Western blots against nitrogenase on diel samples and samples incubated in iron and dust from the Caribbean Sea are 


\section{B -38}

$130 \mathrm{kDa}$

$50 \mathrm{kDa}$

$27 \mathrm{kDa}$

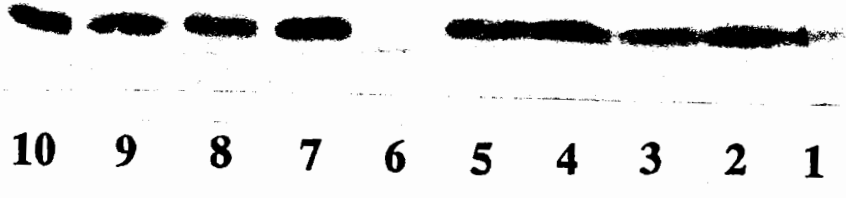

Figure 15. Immunoassay (anti-phycoerythrin) of Trichodesmium colonies in a diel and an iron addition experiment in February 1991 from the Caribbean Sea. 1) 1030 h (Feb. 6); 2) 0400 h (Feb. 7); 3) 1000 h (Feb. 7); 4) 1700 h (Feb. 7); 5) 2200 h (Feb. 7); 6) MW std; 7) control; 8) $\mathrm{FeCl}_{3}$ treatment, 9) dust addition; 10) $1600 \mathrm{~h}$ (Feb. 6). 


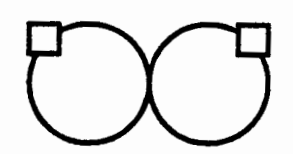

Inactive<smiles>C1=C2CCCC3(CCCCCCC3)CCC12</smiles><smiles>IC1CCCC2(CCCCCC2)CCC1</smiles>

Active

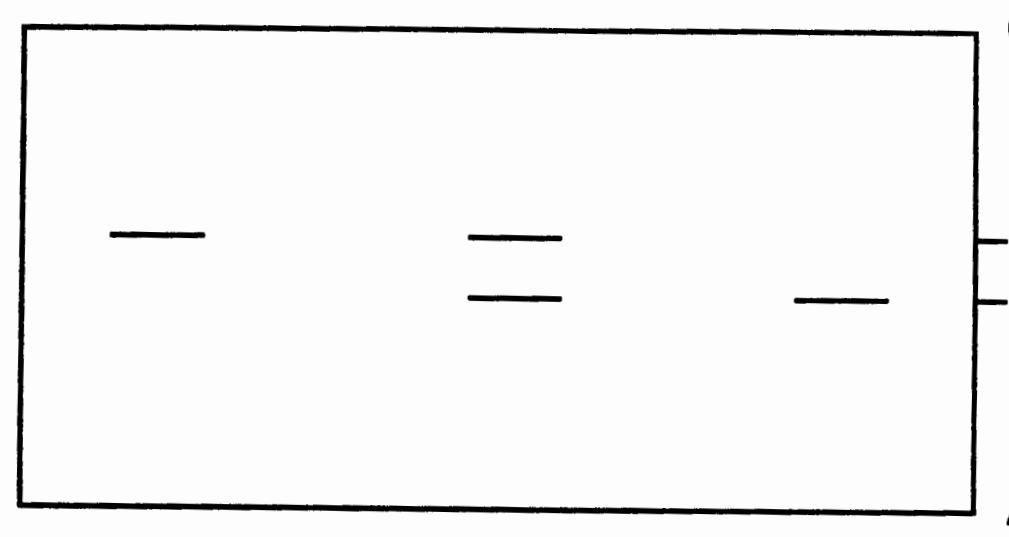

Cathode (-)

Anode ( + )

Figure 16. Schematic diagram of 'modification' (active and inactive form) of the iron protein of nitrogenase (top figure) and how it will appear on a Western blot (bottom figure). 
shown in Blot \#39 (Figure 17) and \#40 (Figure 18). Lanes 1-5 show the changes in the iron protein of nitrogenase over a 24 hour period (Figure 17). The protein is in the inactive, apparently modified, higher molecular weight (approx. $40 \mathrm{kDa}$ ) form at 0400 hours. At 1000 hours the protein becomes demodified and is in the lower molecular weight active form (approx. $38 \mathrm{kDa}$ ). The iron protein in this blot appears to become modified at 1600 hours (Lane 3) where both forms are seen. Complete modification occurs by 2200 and 0400 and only the modified higher form is seen. Trichodesmium colonies were incubated in $\mathrm{FeCl}_{3}\left(1.8 \times 10^{-8} \mathrm{M}\right)$ and in Saharan dust (10 mg. in $200 \mathrm{ml} \mathrm{FSW}$ ) for 26 hours until 0900 hours and are seen in lanes 7-9 (Figure 17). The control (no Fe) is predominantly in the upper, inactive form with a small amount of the lower active form. The colonies incubated in $\mathrm{FeCl}_{3}$ and dust have both forms of the enzyme which is most apparent in the colonies incubated in dust (lane 9). Blot \#40 (Figure 18) shows colonies taken from a 1000 hour tow as time zero for comparison and colonies incubated in $\mathrm{FeCl}_{3}$ and dust for 10 hours. Lane 2 and 8 shows the enzyme in the unmodified active form from the samples taken directly from the tow at 10:00. The colonies incubated in iron and dust for 10 hours were prepared at 20:00 hours. Lane 3 shows the control (no $\mathrm{Fe}$ ) in the inactive higher MW form. Lane 4 and 7 shows the colonies incubated in $\mathrm{FeCl}_{3}$ with the enzyme in the inactive higher $\mathrm{MW}$ form in Lane 4 and with both forms in Lane 7. The colonies incubated in dust are seen in Lane 5 with both forms of the enzyme. 
$1-2=3-4-5-6-7-8-9-10$

$$
\text { B-39 }
$$

Figure 17. Immunoassay B-39 (anti-dinitrogenase reductase) of Trichodesmium colonies in a diel and an iron addition experiment in February 1991 from the Caribbean Sea. 1) 0400 h (Feb. 12); 2) 1000 h (Feb. 12); 3) 1600 h (Feb.12); 4) 2200 h (Feb. 12); 5) 04.00 h (Feb. 13th); 6) MW std; 7) control; 8) $\mathrm{FeCl}_{3}$ addition; 9) dust addition; 10) Void. 


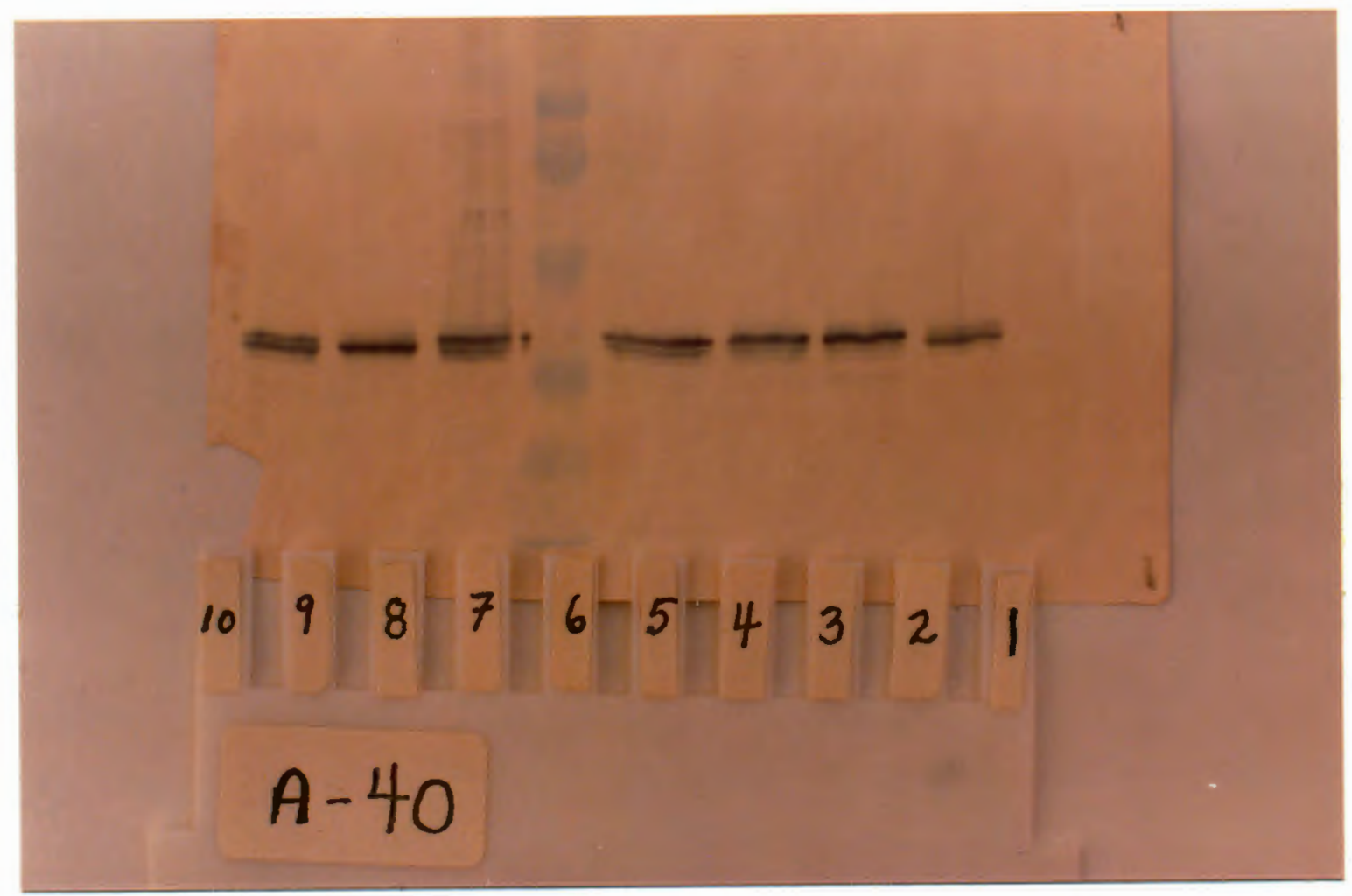

Figure 18. Immunoassay A-40 (anti-dinitrogenase reductase) of Trichodesmium colonies in an iron addition experiment on 14 February, 1991 from the Caribbean Sea. 1) void; 2) $1000 \mathrm{~h}$ time zero; 3) control, 4) $\mathrm{FeCl}_{3}$ addition; 5) dust addition; 6) $\mathrm{MW}$ std; 7) $\mathrm{FeCl}_{3}$ addition; 8) $1000 \mathrm{~h}$ time zero; 9) $1000 \mathrm{~h}$ time zero; 10) void. 
Colonies from the Sargasso Sea did not show a diel change in the iron protein of nitrogenase in April and early May 1991. Blot \#42 (Figure 19) shows puff colonies at various times throughout the day and at all times are seen with both forms of the enzyme. Also on this blot (Figure 19) are colonies incubated in no iron (control), $\mathrm{FeCl}_{3}$ $(1.8 \times 10-8 \mathrm{M})$ and FeEDTA $\left(10^{-8} \mathrm{M}\right)$ for approximately 12 hours until 1800 hours in lanes 6-9. The enzyme shows no changes from the samples of puff colonies collected throughout the day and are seen faintly with both forms of the enzyme. Blot \#41 (Figure 20) shows samples taken at 1530 hours on April 23, 1991 and show again both forms of the enzyme. Colonies were incubated in no iron, $\mathrm{FeCl}_{3}$ and dust for 28 hours are seen in Lanes 4-6. Only Lane 6, the colonies incubated in dust, showed a strong reaction for nitrogenase.

The dominant form of Trichodesmium colonies in the Sargasso Sea during the Spring of 1991 were puff forms. Tuft forms were rarer and collected for comparison on Western Blots for the iron protein of nitrogenase. Blot \#44 (Figure 21) shows puffs in lanes 1, 4 and 8 with a strong signal for the iron protein of nitrogenase. These colonies were collected at mid-day on May 9, 1991, and are seen with both forms of the enzyme. Tufts are seen in lanes 2 and 9 and show a very weak signal for the iron protein of nitrogenase. Later on May 13, 1991, tufts were collected and run in Blot \#45 (Figure 22) in lanes 2, 4 and 9 which show no signal for nitrogenase.

Later, on May 13, 1991, puff colonies appeared to show a diel shift in the iron protein of nitrogenase. This is seen in lane 5 with colonies collected at 1230 hours (Figure 22). 


\section{$10-9-8-7-6-5-4-3-2-1$}

\section{$B-42$}

Figure 19. Immunoassay B-42 (anti-dinitrogenase reductase) of Trichodesmium colonies in a diel and an iron addition experiment in April 1991 from the BATS station in the Sargasso Sea. 1) 2000 h (Apr. 29); 2) 2400 h (Apr. 29); 3) 0700 h (Apr. 30); 4) 1530 h (Apr. 30); 5) MW std; 6) control; 7) $\mathrm{FeCl}_{3}$ addition; 8) dust addition; 9) $\mathrm{FeCl}_{3}+$ EDTA addition; 10) $1800 \mathrm{~h}$ (Apr. 30). 


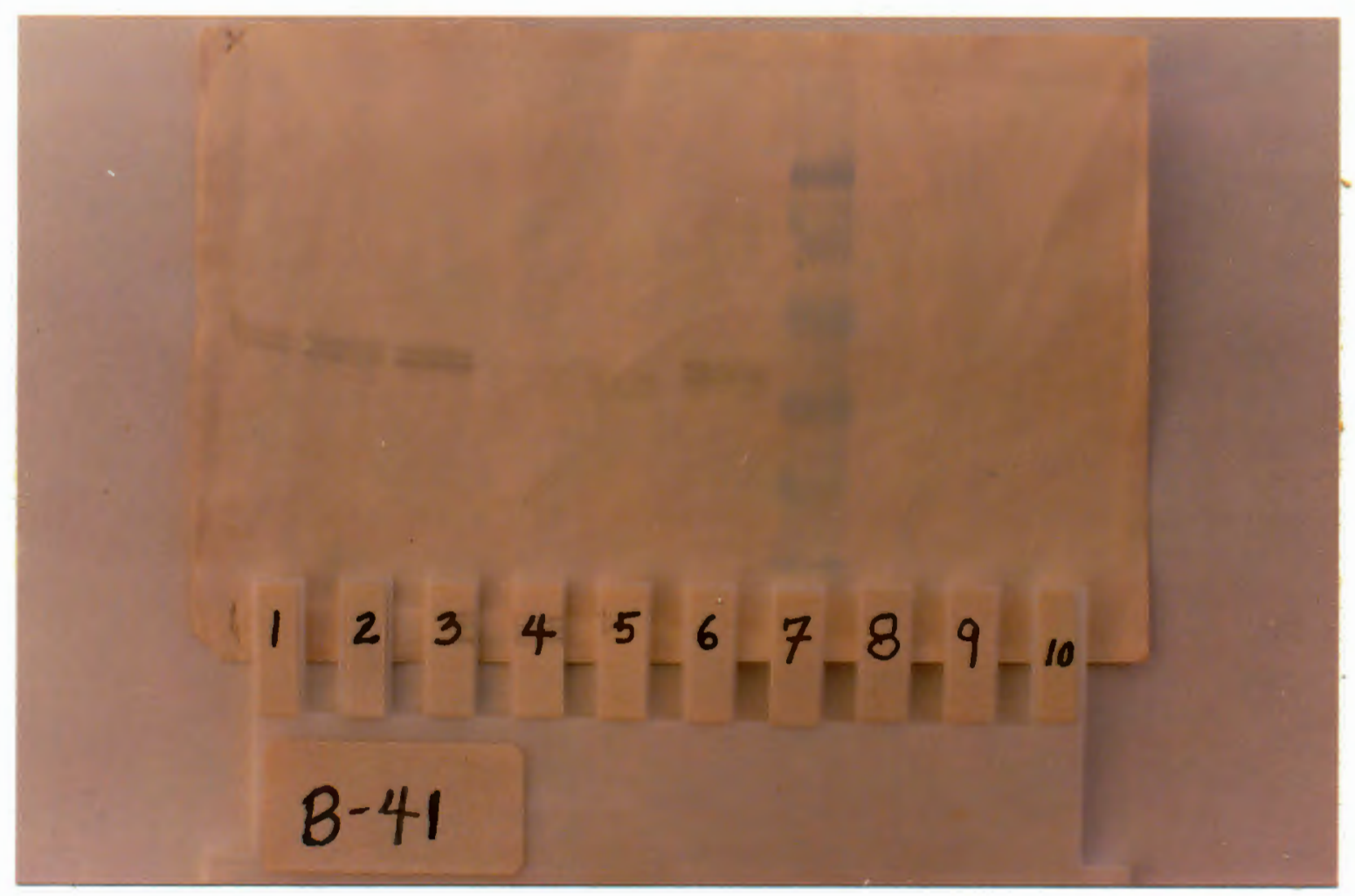

Figure 20. Immunoassay B-41 (anti-dinitrogenase reductase) of Trichodesmium colonies in an iron addition experiment on 23 April, 1991 from Hydrostation ' $S$ ' in the Sargasso Sea. 1-3) $1530 \mathrm{~h}$; 4) control; 5) $\mathrm{FeCl}_{3}$ addition; 6) dust addition; 7) MW std; 8-10) void. 


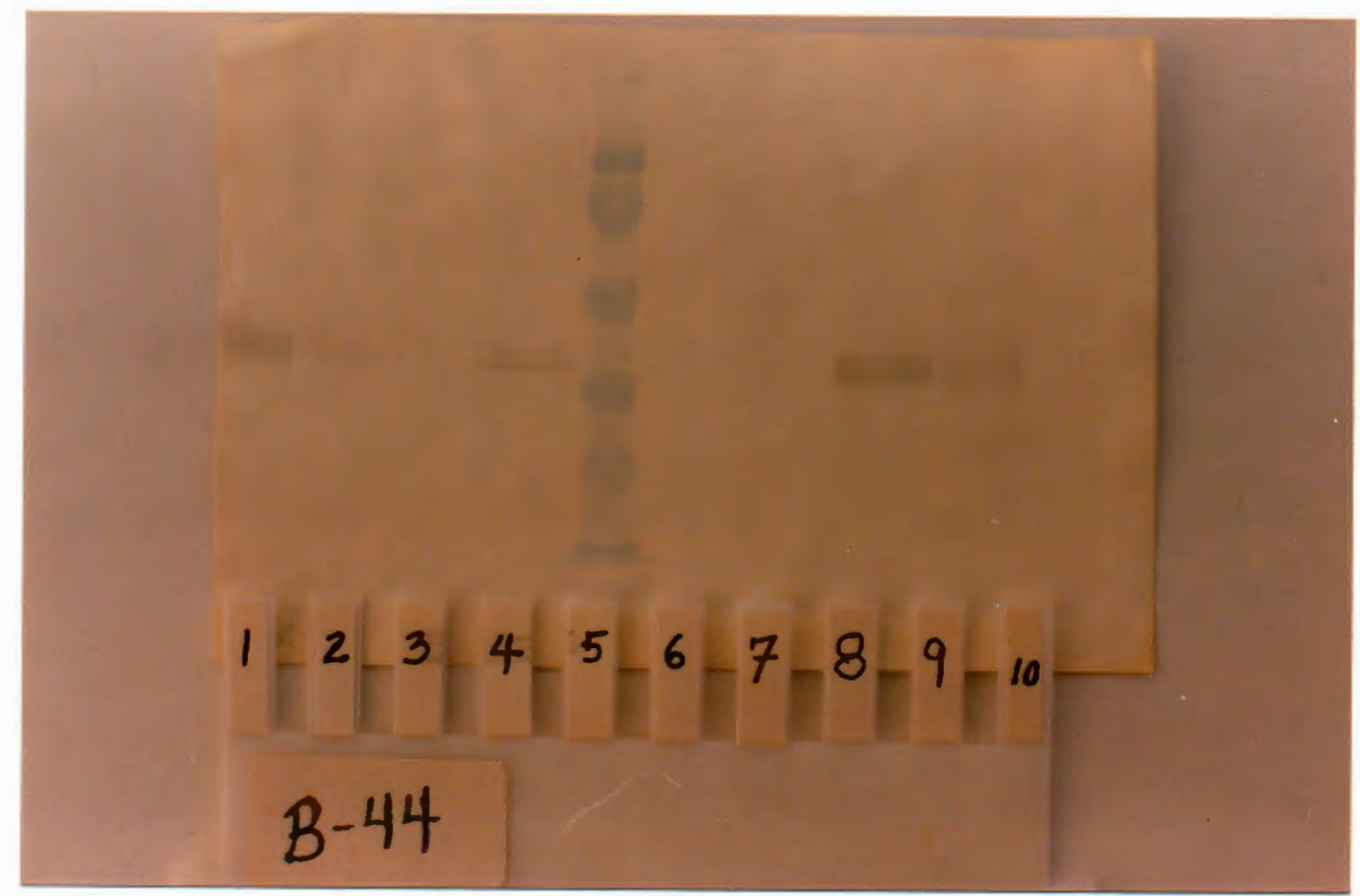

Figure 21. Immunoassay B-44 (anti-ditrogenase reductase) of Trichodesmium colonies (puff and tuft comparison) on 9 May, 1991 from Hydrostation ' $S$ ' in the Sargasso Sea. 1) puffs $1200 \mathrm{~h}$; 2) tufts $1200 \mathrm{~h}$; 3) void; 4) puffs $1200 \mathrm{~h}$; 5) MW std; 6-7) void; 8) puffs $1200 \mathrm{~h}$; 9) tufts $12.00 \mathrm{~h}$; 10) Void. 


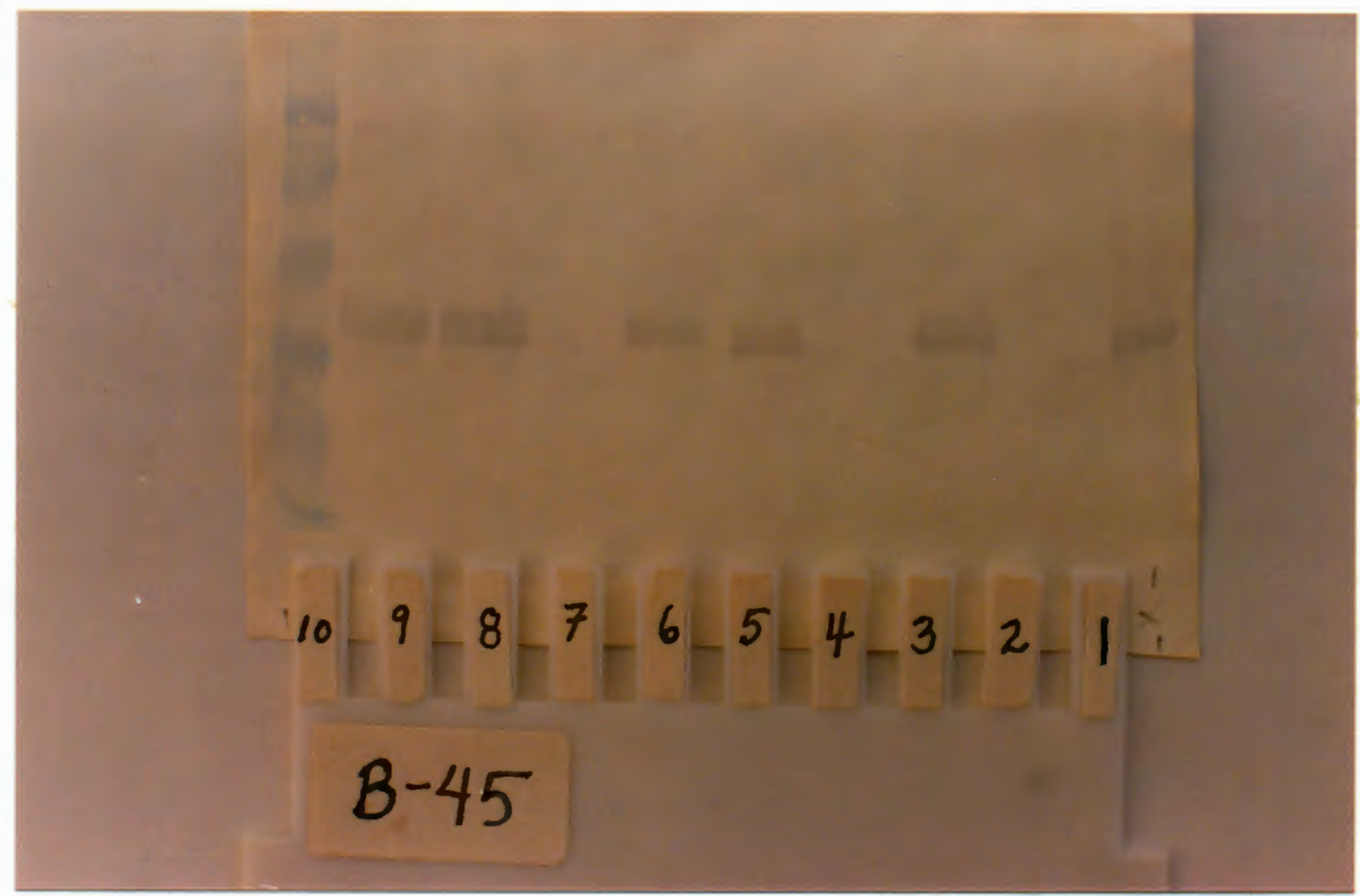

Figure 22. Immunoassay B-45 (anti-dinitrogenase reductase) of Trichodesmium colonies (puff and tuft comparison) in a diel experiment in May, 1991 at BATS station in the Sargasso Sea. 1) puffs $1830 \mathrm{~h}$ (May 13); 2) tufts $2400 \mathrm{~h}$ (May 13); 3) puffs 0030 h (May 14); 4) tufts 1230 h (May 14); 5) puffs $1230 \mathrm{~h}$ (May 14); 6) puffs $0500 \mathrm{~h}$ (May 14); 7) tufts 0500h (May 14); 8-9) puffs 0500 h (May 14); 10) MW std. 
Hydrography of the Sargasso and Caribbean Seas

During April 1991 in the Sargasso Sea, there was significant nitrate in the euphotic zone from recent mixing. Figure 23 shows nitrate and nitrite in the euphotic zone. Nitrate and nitrite had recently been depleted from the upper euphotic zone and there were significant amounts in the lower euphotic zone. Two weeks later in May there appeared to be a change in the migrating pattern of the iron protein with a shift in molecular weight of the iron protein to the lower active form (Figure 22). There was a concomitant decrease in the nitrate and nitrite levels in the euphotic zone with a corresponding increase in the peak of fluorescence (Figure 24, 25). The CTD profiles in Figure 24 and Figure 25 show the shallow thermocline in the Sargasso Sea that is a result of recent mixing and the deeper thermocline in the Caribbean Sea (Figure 26). Also seen from the CTD profile presented in Figure 26 and Figures 24, 25 is the different temperatures of the Caribbean Sea at $26^{\circ} \mathrm{C}$ and the Sargasso Sea at $21^{\circ} \mathrm{C}$ respectively. The hydrographical profiles show the different environmental conditions that were present in the two seas.

\section{Acetylene Reduction and Iron Additions}

Rates of acetylene reduction were highest at midday and decreased in late afternoon (Figure 27). Results from acetylene reduction experiments with iron additions are presented in Table II for the short-term incubations $(<5$ hrs.) and Table III for the longterm incubations ( $>5$ hrs). Results from April 1990 show a slightly higher average rate of acetylene reduction in colonies exposed to 


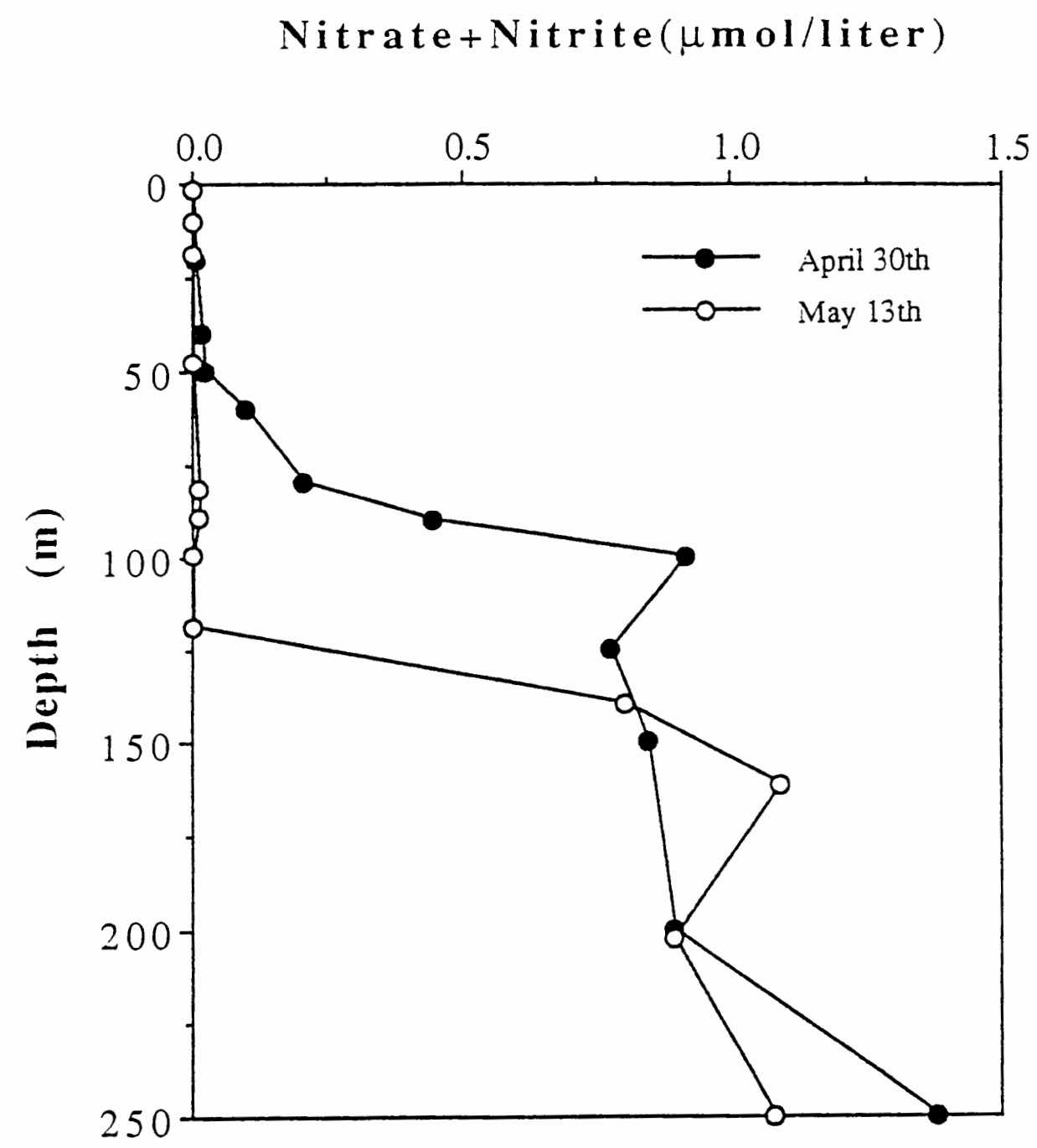

Figure 23. Vertical profile of nitrate + nitrite at BATS station in the Sargasso Sea in April and May 1991. 
Salinity $(p p t)$

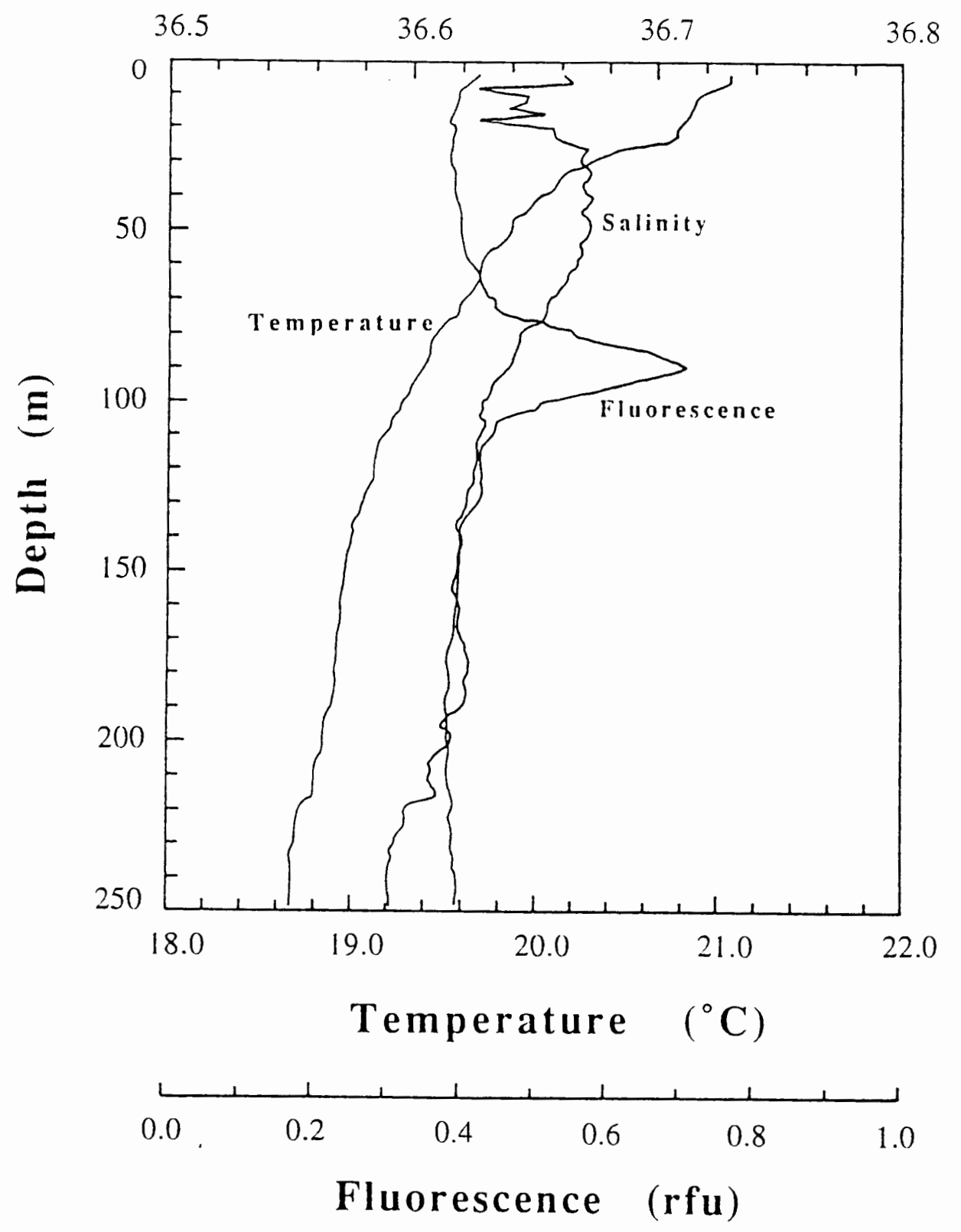

Figure 24. Vertical profile of salinity, temperature and fluorescence $(\mathrm{rfu}=$ relative fluorescence units) at BATS station in the Sargasso Sea on 30 April, 1991. 


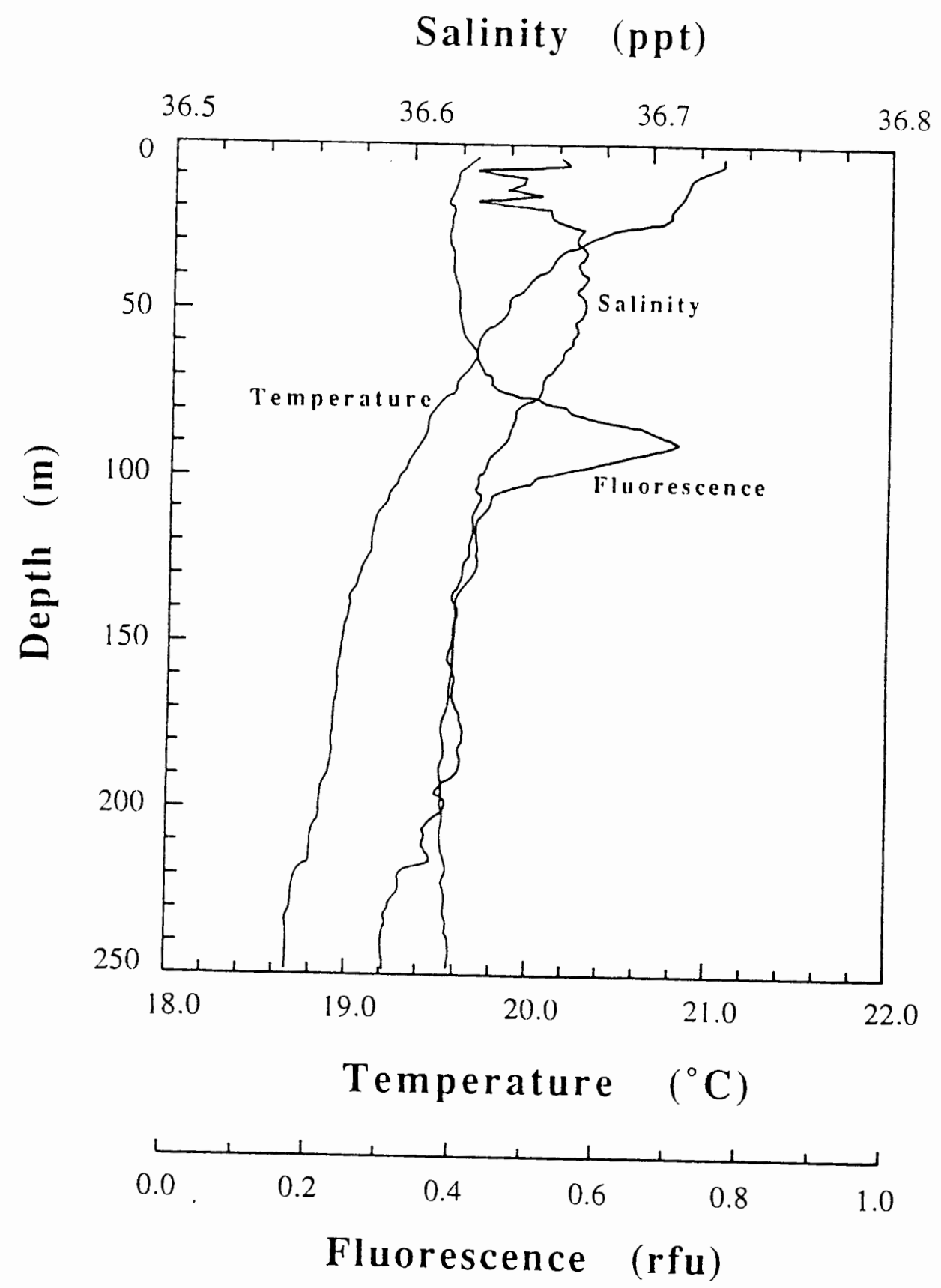

Figure 24. Vertical profile of salinity, temperature and fluorescence ( $\mathrm{rfu}=$ relative fluorescence units) at BATS station in the Sargasso Sea on 30 April, 1991. 
Temperature $\left({ }^{\circ} \mathrm{C}\right)$

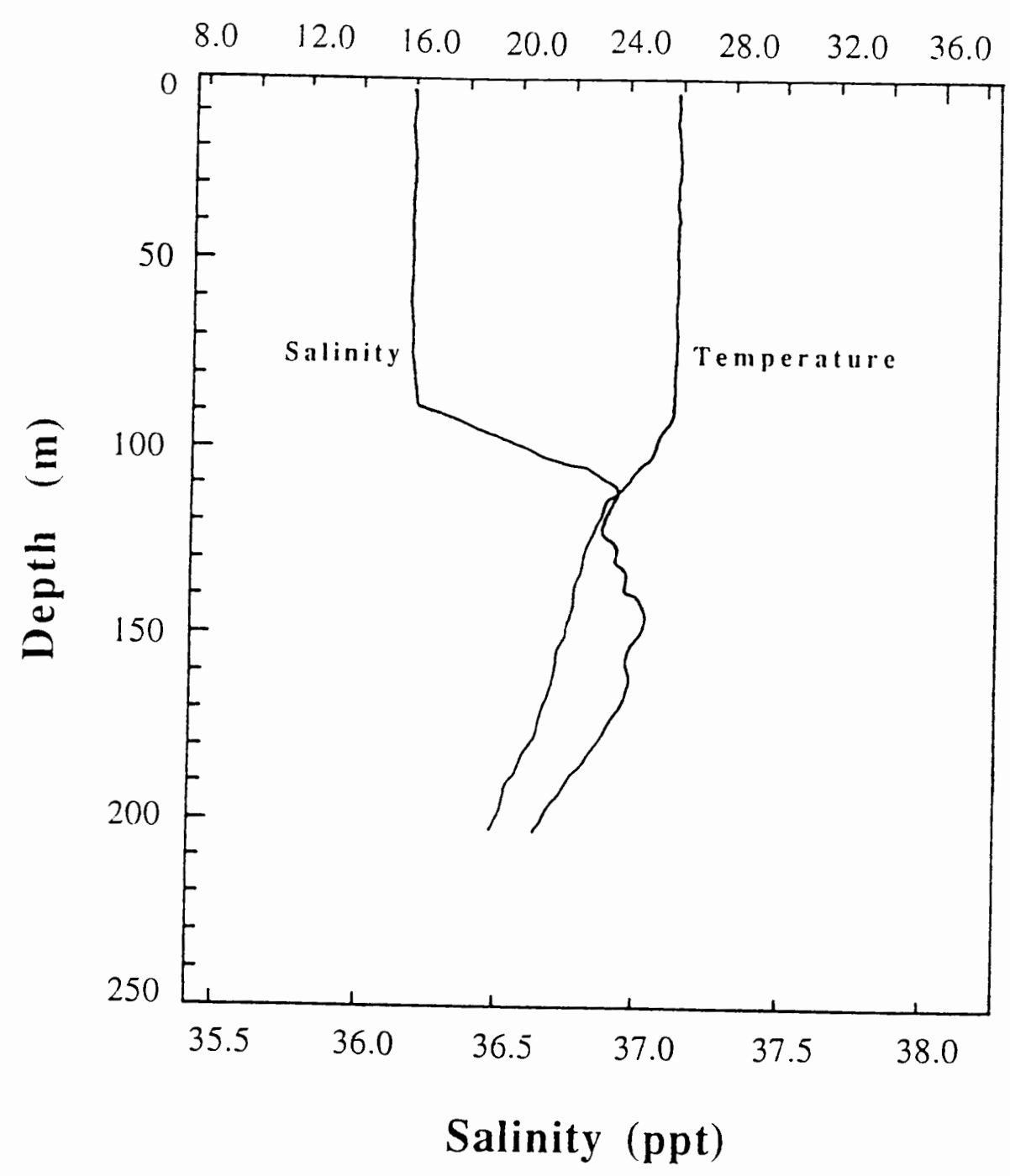

Figure 26. Vertical profile of salinity and temperature in the Caribbean Sea on 4 February, 1991. 


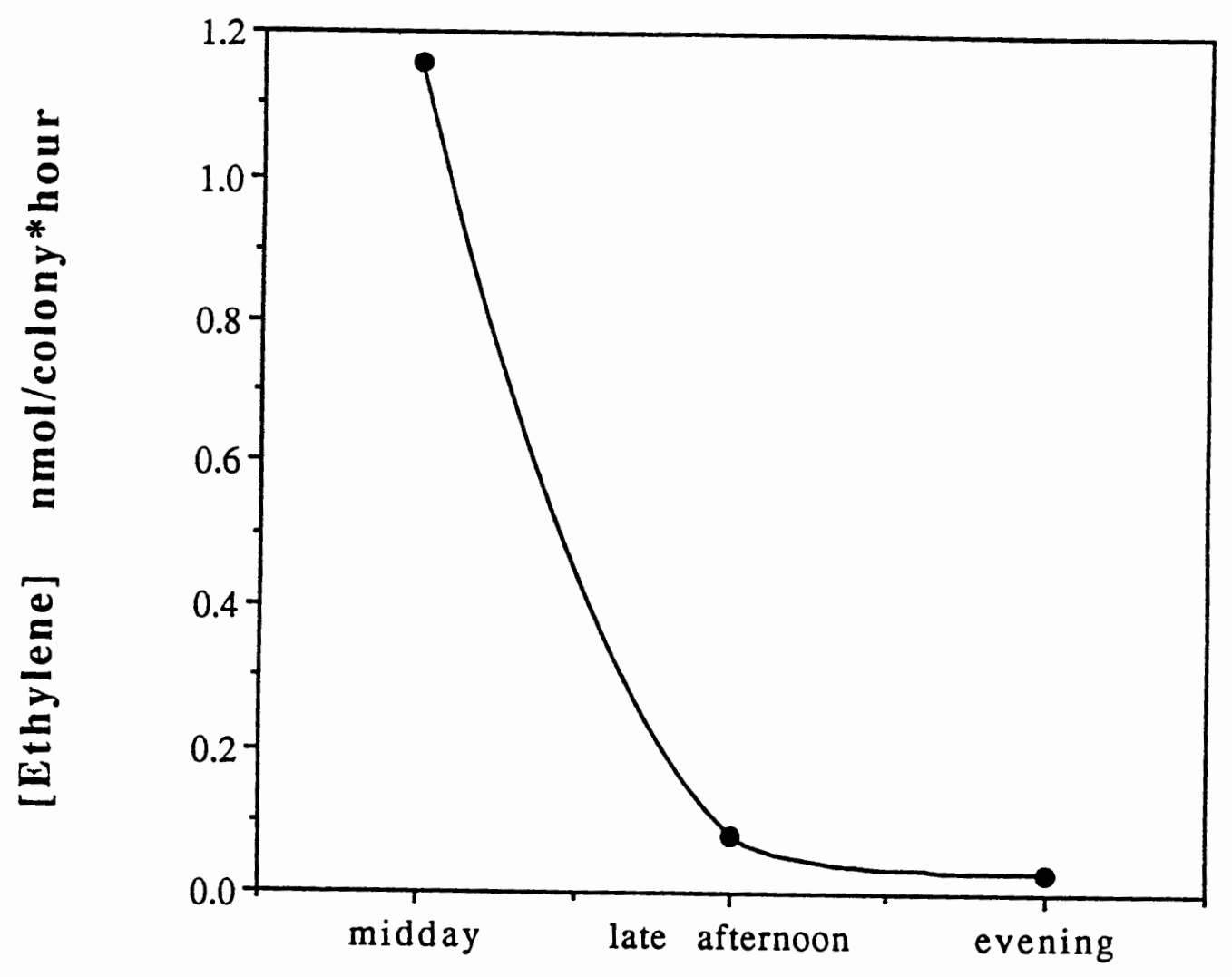

Time of day

Figure 27. Acetylene reduction measured as ethylene production rate (average per colony $*$ hour) as a function of time of the day. 


\section{TABLE II}

AVERAGE ACETYLENE REDUCTION RATES (nmol Ethylene/colony*hour) FOR TRICHODESMIUM IN A SHORT TERM INCUBATION (LESS THAN 5 HOURS), WITH IRON ADDITIONS. $\mathrm{FeCl}_{3}$ and $\mathrm{FeCl}_{3}+\mathrm{EDTA}=1.8^{*} 10^{-8} \mathrm{M} \mathrm{Fe}$, Dust $=4.5^{*} 10^{-6} \mathrm{M}$ Fe. STANDARD DEVIATION ( SD $\left._{n-1}\right)$ BETWEEN REPLICATE LINEAR INTEGRATIONS ARE GIVEN IN PARANTHESIS. ND = No Data. ${ }^{* * *}=$ AVERAGE OF $3, * *=$ AVERAGE OF 2 AND * = AVERAGE OF 1 REPLICATE LINEAR REGRESSION(S).

\begin{tabular}{|c|c|c|c|c|}
\hline Date & Control & $\mathrm{FeCl}_{3}$ & Dust & $\mathrm{FeCl}_{3}+\mathrm{EDTA}$ \\
\hline $\begin{array}{l}\text { April 16th, } 1990 \\
(0.254)\end{array}$ & $\begin{array}{l}0.315^{* * *} \\
(0.177)\end{array}$ & $\begin{array}{l}0.586^{* * *} \\
(0.113)\end{array}$ & $0.352^{* * *}$ & ND \\
\hline February 5th, 1991 & $0.297^{*}$ & $\begin{array}{l}0.444^{* *} \\
(0.404)\end{array}$ & $\begin{array}{l}0.189^{* *} \\
(0.006)\end{array}$ & ND \\
\hline February 6th, 1991 & $\begin{array}{l}0.648^{* *} \\
(0.082)\end{array}$ & $\begin{array}{l}0.271^{* *} \\
(0.006)\end{array}$ & $\begin{array}{l}0.272^{* *} \\
(0.057)\end{array}$ & $\mathrm{ND}$ \\
\hline February 7 th, 1991 & $\begin{array}{l}1.663^{* * *} \\
(0.081)\end{array}$ & $\begin{array}{l}1.227^{* * *} \\
(0.224)\end{array}$ & $\mathrm{ND}$ & $\mathrm{ND}$ \\
\hline January 20th, 1992 & $\begin{array}{l}0.439^{* *} \\
(0.119)\end{array}$ & $\begin{array}{l}0.530^{* *} \\
(0.013)\end{array}$ & $\begin{array}{l}0.259^{* *} \\
(0.059)\end{array}$ & $\begin{array}{l}0.374^{* *} \\
(0.196)\end{array}$ \\
\hline January 22nd, 1992 & $\begin{array}{l}0.161^{* *} \\
(0.021)\end{array}$ & $\begin{array}{l}0.228^{* *} \\
(0.070)\end{array}$ & $\begin{array}{l}0.076^{* *} \\
(0.059)\end{array}$ & $\begin{array}{l}0.065^{* *} \\
(0.049)\end{array}$ \\
\hline January 23rd, 1992 & $\begin{array}{l}0.042^{* * *} \\
(0.024)\end{array}$ & $\begin{array}{l}0.071^{* * *} \\
(0.033)\end{array}$ & $\begin{array}{l}0.058^{* * *} \\
(0.033)\end{array}$ & $\begin{array}{l}0.026^{* * *} \\
(0.024)\end{array}$ \\
\hline August 30th, 1992 & $\begin{array}{l}0.358^{* *} \\
(0.080)\end{array}$ & $\begin{array}{l}0.309^{* *} \\
(0.058)\end{array}$ & $\begin{array}{l}0.191^{* *} \\
(0.001)\end{array}$ & $\mathrm{ND}$ \\
\hline
\end{tabular}




\section{TABLE III}

AVERAGE ACETYLENE REDUCTION RATES (nmol Ethylene/colony*hour) FOR TRICHODESMIUM IN A LONG TERM INCUBATION (5-20 HOURS), WITH IRON AND EDTA ADDITIONS. APRIL 1990 AND FEBRUARY 1991; FeCl ${ }_{3}$ and $\mathrm{FeCl}_{3}+\mathrm{EDTA}=1.8^{*} 10^{-8} \mathrm{M} \mathrm{Fe}$, Dust $=4.5^{*} 10^{-6} \mathrm{M}$ Fe. JANUARY 29th, $1992 ; \mathrm{FeCl}_{3}=1.8^{*} 10^{-7} \mathrm{M} \mathrm{Fe}, \mathrm{Dust}=9.0^{*} 10^{-6} \mathrm{M}$ Fe,

$\mathrm{FeCl}_{3}+\mathrm{EDTA}=1.8^{*} 10^{-7} \mathrm{M}$ Fe. JANUARY 31st, $1992 ; \mathrm{FeCl}_{3}=1.8^{*} 10^{-7} \mathrm{M}$ Fe, Dust $=9.0^{*} 10^{-6} \mathrm{M}$ Fe, EDTA $=1.0^{*} 10^{-6} \mathrm{M}$ EDTA. STANDARD DEVIATION (SD $\left.\mathrm{S}_{\mathrm{n}-1}\right)$ BETWEEN REPLICATE LINEAR INTEGRATIONS ARE GIVEN IN PARANTHESIS. ND $=$ No Data. ${ }^{* * *}=$ AVERAGE OF $3, * *=$ AVERAGE OF 2 AND $*=1$ REPLICATE LINEAR REGRESSION(S).

$\begin{array}{lccccc}\text { Date } & \text { Control } & \mathrm{FeCl}_{3} & \text { Dust } & \mathrm{FeCl}_{3}+\mathrm{EDTA} & \text { EDTA } \\ \text { April 16th, 1990 } & \begin{array}{c}0.011^{* * *} \\ (0.015)\end{array} & \begin{array}{c}0.030^{* * *} \\ (0.035)\end{array} & \begin{array}{c}0.012^{* * *} \\ (0.014)\end{array} & \mathrm{ND} & \mathrm{ND} \\ \text { February 7th, 1991 } & \begin{array}{c}0.810^{* * *} \\ (0.329)\end{array} & \begin{array}{c}0.537^{* * *} \\ (0.113)\end{array} & \begin{array}{c}0.725^{* * *} \\ (0.349)\end{array} & \mathrm{ND} & \mathrm{ND} \\ \text { January 29th, 1992 } & 0.160^{* *} & 0.192^{* *} & 0.138^{* *} & 0.016^{* *} & \mathrm{ND} \\ & (0.069) & (0.000) & (0.165) & (0.008) & \\ \text { January 31st, 1992 } & 0.190^{* *} & 0.089^{* *} & 0.062^{* *} & \mathrm{ND} & 0.151^{* *} \\ & (0.122) & (0.049) & (0.054) & & (0.148)\end{array}$


$\mathrm{FeCl}_{3}\left(1.8 \times 10^{-8} \mathrm{M}\right)$ but not a significantly higher rate. A short-term incubation (iron added directly to vial) experiment and a longer term (5 $1 / 2$ hours) showed similar results. This experiment was repeated in February 1991 and the opposite result was obtained. Iron in the form of $\mathrm{FeCl}_{3}$ had lower average acetylene reduction rates in both short term (iron added directly to vials) and long-term ( 9 hrs) incubation experiments.

In January 1992, experiments with iron additions were repeated with the addition of $\mathrm{FeCl}_{3}\left(1.8 \times 10^{-8} \mathrm{M}\right)$, dust $(10 \mathrm{mg}$ in $200 \mathrm{ml} \mathrm{FSW})$ and with the addition of FeEDTA $\left(10^{-8} \mathrm{M}\right)$. Colonies were incubated in the iron solutions for $31 / 2$ hours and yielded slightly higher average $\mathrm{AR}$ rates with the $\mathrm{FeCl}_{3}$, but, the rates were not significantly higher than in the no-iron control. Experiments were repeated for three consecutive days in which iron was added directly to assay vials at 1300 hours. On two of those days $\mathrm{FeCl}_{3}$ had a slightly higher average AR rate but the difference was insignificant when compared to control samples. Concentrations of $\mathrm{FeCl}_{3}$ and FeEDTA were increased to $10^{-7} \mathrm{M}$ and dust was increased to $20 \mathrm{mg}$ in $200 \mathrm{ml} \mathrm{FSW}$ in an overnight incubation (approximately $20 \mathrm{hr}$ ) on Jan. 29, 1992, and resulted in no stimulation of AR rates. This experiment was repeated with colonies collected on a blue water dive on Jan. 30,1992 , but with the addition of EDTA only $\left(10^{-6} \mathrm{M}\right)$ instead of FeEDTA. Iron and dust solutions yielded slightly lower average $A R$ rates and the EDTA solution had rates similar to that of the control. 
An additional experiment was conducted in August 1992 with the original conditions of $\mathrm{FeCl}_{3}\left(1.8 \times 10^{-8} \mathrm{M}\right)$ and dust $(10 \mathrm{mg}$ in 200 ml FSW). Colonies were incubated for three hours in the morning before acetylene was added. Colonies incubated in dust had the lowest average $\mathrm{AR}$ rates and $\mathrm{FeCl}_{3}$ did not produce a stimulatory effect. 


\section{DISCUSSION}

\section{Protein and Iron Content}

Results from this study show intercolonial variation in protein content that ranged from 9.7-26 $\mu \mathrm{g}$ per colony. Using the same method, Hutchins (1989) reported a range of 5.1-20.4 $\mu \mathrm{g}$ protein per colony and Rueter (1988b) reported a range of 4.8-7.9 $\mu \mathrm{g}$ protein per colony forTrichodesmium from the Caribbean Sea. As seen in Table I, growth rates and nitrogen fixation rates vary in historical literature. Part of the discrepancy in reported turnover times for cellular nitrogen in Trichodesmium is a result of variable amounts of nitrogen per colony. Carpenter (1973) used a value of $1.5 \mu \mathrm{g} \mathrm{N}$ per colony and Carpenter et al. (1987) used a value $0.2 \mu \mathrm{g} \mathrm{N}$ per colony. The protein nitrogen per colony from this thesis ranged from 1.1 to $4.3 \mu \mathrm{g}$ per colony based on the assumption that $14 \%$ of protein is nitrogen (Dayhoff et al. 1965). Elemental analysis of particulate organic nitogen content in Trichodesmium colonies have shown that this estimate is accurate (Elardo, unpub. data). This demonstrates the importance of determining biomass of the population studied and to avoid adopting average estimates from other sources.

Acid leachable iron content was higher in April 1990 than February 1991 (Figure 7 and Figure 8). During the diel in April 1990 cellular iron was lower in the dark hours of the day and increased in the daylight (Figure 7). During this month, iron may have been more 
available in the daylight due to the process of photoreduction which produces ferrous iron (Rich and Morel 1990, Wells and Mayer 1991). An interesting question that arises is why would Trichodesmium lose iron or release iron if iron as a micronutrient is limiting? One possibility is that this particular population was iron replete and reached a capacity to store excess iron.

The lower iron values during February 1991 coupled with the relatively higher protein content produced high $\mathrm{N} / \mathrm{Fe}$ ratios (Figure 10). The N/Fe data show that Trichodesmium have a higher limit of $\mathrm{N} / \mathrm{Fe}$ ratio than previously thought (Hutchins 1988). Rueter (1989) estimated from data in the Caribbean Sea and near Barbados that Trichodesmium would have $\mathrm{N} / \mathrm{Fe}$ ratios of 1000 . His measurements ranged from 60-140 pmol per colony. The lowest measurements in pmol obtained in this thesis during February 1990 ranged from 81371 pmol per colony with $\mathrm{N} / \mathrm{Fe}$ ratios near 3000 . Rueter and Unsworth (1991) found a N/Fe ratio of 2700 for cultures of marine Synechococcus grown in $10^{-8} \mathrm{M} \mathrm{Fe}$. They concluded that rapidly growing populations of marine phytoplankton could be expected to have $\mathrm{N} / \mathrm{Fe}$ ratios of 3000 to 1500 in order to grow fast enough to avoid predation and sinking. Nitrogen doubling times for Trichodesmium have been estimated to be from 105 days (Carpenter and McCarthy 1975) to 1.5 days (Carpenter et al. 1987) which indicate that at times, growth can be very rapid. Such a magnitude of variation in growth rates could produce a large variation in $\mathrm{N} / \mathrm{Fe}$ ratios. 
Clearly, cellular iron concentrations are highly variable in Trichodesmium colonies. The highest average concentration of acid leachable cellular iron during April 1990 was 817 pmol per colony (Figure 7). Trichodesmium colonies most likely obtain these high levels from a source outside of the oceanic environment. Data from the N. Atlantic ocean show that particulate and dissolved iron reached approximately $1.1 \mathrm{nmol}$ in the upper 50 meters during April 1989 (Powell et al. 1994). Dry and wet iron deposition to Bermuda had a seasonal peak between April and November in the years 19891990 (AEROCE data, T. Church, unpub. data). The highest peak was in September and in 1989 reached 50,000 pmole $/ \mathrm{cm}^{2}$. Rueter et al. (1992) showed evidence of Trichodesmium colonies adhering to dust particles and proposed this mechanism as the major source of iron acquisition. The seasonal dust input may explain the high levels of cellular iron obtained during April 1990.

\section{SDS-PAGE}

Changes in proteins subjected to SDS-PAGE were observed in samples of Trichodesmium (Figures 12, 13, 14). The unknown protein(s) observed had an apparent molecular weight near $26 \mathrm{kDa}$ and $25 \mathrm{kDa}$. The proteins changed on diel samples and also with iron and dust additions. Iron and dust additions caused changes in the proteins that resulted in the two forms being present at once. Because the protein bands responded to iron additions, it was thought that they may be involved in iron storage as a ferritin-like protein. Phytoferritin, the iron complexing protein found in plants, 
has 24 identical subunits with molecular weights 20 to $28 \mathrm{kDa}$ (Briat et al. 1988). Bacterioferritin isolated from the cyanobacterium Synechocystis P.C.C. 6803 has a subunit molecular weight of $19 \mathrm{kDa}$ (Laulhere et al. 1992). The unknown proteins had a close proximity to the molecular weight of bacterioferritin but did not stain with iron specific stains. Prussian blue was not sensitive enough and did not stain any protein on the gel. Bathophenanthroline is more sensitive but did not react with Trichodesmium proteins. The proteins may not have been concentrated enough for the reaction and when restained with coomassie blue showed faint bands that indicated this. However, equine ferritin did react at approximately $3 \mu \mathrm{g}$. Equine ferritin was used as a standard because all ferritins whether animal or plant share structural properties (Theil 1987).

Phycoerythrin was ruled out as the identity of the unknown proteins by Western blot immunoassay (Figure 15). On diel studies, phycoerythrin subunits do not change in molecular weight but remain consistent throughout the day and night (Figure 15). However, because of low protein on the gels, the role of an iron storage protein can not be ruled out.

\section{Immunoassays for Dinitrogenase Reductase}

Changes in the iron protein of nitrogenase (dinitrogenase reductase) was observed in diel samples from the Caribbean Sea and in samples incubated in iron and dust. The changes in molecular weight of the subunits of dinitrogenase reductase are referred to here as a "modified" form although the molecular basis for the 
change in molecular weight is not known. Diel samples in the Caribbean Sea showed a diel shift from the active unmodified form in the daytime to a modified form at night (Figures 17, 18). Both of the identical subunits of dinitrogenase reductase became modified at night. An interesting observation in the diel studies for this population was that dinitrogenase reductase was present early in the morning at 0400 hours in the modified form (Figure 17). The population of Trichodesmium in this study appear to undergo reversible modification of dinitrogenase reductase without degradation of the enzyme. In an earlier report Capone et al. (1990) concluded that modification of dinitrogenase reductase in Trichodesmium is a product of de novo synthesis and degradation. Du and Gallon (1993) found this process also in Gleothece. Zehr et al. (1993) concluded that in natural populations of Trichodesmium a diel cycle of synthesis and degradation accompanies the modification of the Fe protein. However, in cultures of Trichodesmium, Ohki et al. (1992) found the Fe protein present over a 24 hour period. In studies with Anabaena, Ernst et al. (1990a) found that reversible modification is more significant than de novo synthesis. It is proposed in this thesis, at least for the Caribbean population studied in this thesis, that reversible modification occurs in Trichodesmium. It is much more efficient to cap the unused enzyme and protect it from oxygen by "modifying" when not in use and simply lop off the modifier and have a ready made active enzyme.

Caribbean Sea populations of Trichodesmium incubated with dust, and in most cases soluble iron, resulted in the expression of 
both forms of the subunits of the iron protein even after nitrogen fixation ceases and the control (no $\mathrm{Fe}$ ) is in the inactive modified form (Figures 17, 18). This means that either half of the colonies have modified iron protein or the colonies have only one of the identical subunits modified. Under the influence of oxygen only, Anabaena converts both subunits to the modified form but, in the presence of ammonium chloride, modified and non-modified forms are found in equal amounts (Reich and Boger 1989). Possibly, nutrients may cause a different response in the modification of dinitrogenase reductase. Since oxygen irreversibly destroys nitrogenase, modification of dinitrogenase reductase is believed to be an oxygen protection mechanism. It may be possible that this mechanism works in a different way when exposed to different nutrient regimes. This may represent an ancient adaptation that evolved when the presence of oxygen became a problem for diazotrophs and now this system is used as a regulating system for nitrogen fixation secondarily. An example similar to this would be the peptides metallothionein in animals and phytochelatin in plants that function as intercellular chelators that originally sequestered trace metals and maintained metal homeostasis for nutritional purposes but with the increase of heavy metals in the environment due to pollution are also used to detoxify (Grill et al. 1987).

Trichodesmium colonies from the Sargasso Sea however did not show a diel change in subunits of the iron protein of nitrogenase (Figure 19). Instead, both forms of the iron protein in a $1: 1$ distribution were present at all times in the puff form colonies. Tuft 
form colonies did not show a strong signal for nitrogenase (Figures 21, 22). The dominate colony form in the Sargasso Sea in Spring was the puff forms. During summer however, tufts become the dominate form. It appears that the two colonial morphologies of Trichodesmium have different physiologies. This is quite interesting since all of the Caribbean colonies used in experiments were tuft forms.

\section{Hydrographical Influence on Dinitrogenase Reductase in}

\section{Trichodesmium in the Sargasso and Caribbean Seas}

The Caribbean Sea is a permanently stratified oligotrophic ocean as shown in a CTD profile from February 1991 (Figure 26). The Sargasso Sea undergoes strong seasonal patterns of production, biomass and sinking flux (Menzel and Ryther 1960, Deuser 1986, Lohrenz et al. 1992, Michaels et al. 1994). The spring is characterized by a phytoplankton bloom that is a result of convective mixing in the winter which injects nutrients from deeper water to the surface layers. In April 1991, nitrate and nitrite were present in the euphotic zone as a result of recent mixing (Figure 23). This source of inorganic nitrogen may have affected the iron protein of Trichodesmium resulting in the expression of both forms of the subunits during the day instead of only the active, unmodified form. Goering et al. (1966) showed by using $15 \mathrm{~N}$ uptake Trichodesmium in the Atlantic Ocean to fix nitrogen and take up nitrate simultaneously. However, Carpenter and McCarthy (1975) found no significant uptake in $15 \mathrm{~N}$-nitrate. In the Carpenter and McCarthy (1975) study, 
Trichodesmium from the oligotrophic Sargasso Sea were incubated in nitrate for only 2 hours in seawater from the most oligotrophic station. The Goering et al. (1966) study assayed colonies that were near the Amazon River plume and were influenced by nitrate from the river. Studies with nitrate reductase in phytoplankton have shown that the enzyme is induced by nitrate and nitrate reductase is present only if water contained nitrate (Eppley et al. 1969). Trichodesmium from the Sargasso Sea in April 1991 in this study could have been induced because of the presence of nitrate in the water column. As the nitrate decreased because of uptake by phytoplankton, Trichodesmium switched to nitrogen fixation as a source of nitrogen. Figure 22 shows that at this time changes occurred in the iron protein. Studies in the regulation of nitrogen fixation in cultures of Trichodesmium found that inorganic nitrogen repressed nitrogenase activity and only the single modified (inactive) form of the iron protein appeared in Western blots (Ohki et al. 1991). However, the cultures had both forms of the enzyme when actively fixing nitrogen. Anabaena was observed to have both forms of the iron protein in the presence of ammonia (Reich and Boger 1989, Ernst et al. 1990b) and Smith et al. (1987) showed that when both forms of the iron protein were present in Anabaena, it did not always result in a decrease in acetylene reduction.

The temperature of the Sargasso Sea surface water in April and early May 1991 was $21^{\circ} \mathrm{C}$ which is approaching the thermal minimum for physiologically active colonies. Mainly puff forms were found and tuft forms were rare. Actively growing populations rarely 
occur in water colder than $20^{\circ} \mathrm{C}$ (Carpenter 1983b). Maximum photosynthetic activity occurs at $30^{\circ} \mathrm{C}$ with a sharp decline below $20^{\circ} \mathrm{C}$ and above $35^{\circ} \mathrm{C}$ (Carpenter and Capone 1983).

\section{Acetylene Reduction Assay and Iron Additions}

Acetylene reduction (AR) rates with iron additions showed no significant stimulatory effect (Tables II, III). Trichodesmium colonies that showed slightly higher average rates in April 1990 also had high cellular iron. If these colonies were pre-exposed to iron in situ, perhaps they have synthesized specific iron uptake porter proteins and are able to take up iron in a relatively short time. Colonies incubated in iron in February 1991 had slightly lower average $A R$ rates and lower cellular iron. These colonies may not be able to take up iron in short term incubations. However, this is only speculative since the changes in AR rates with iron additions are not significantly different from control rates. Interestingly, the highest overall AR rates were during Feburary 1991 when cellular iron was low.

Similar results for nitrogen fixation rates for Trichodesmium at $10^{-8} \mathrm{M} \mathrm{Fe}$ were presented by Rueter (1988). Although his study showed no stimulation in $\mathrm{AR}$ rates with $10^{-8} \mathrm{M} \mathrm{Fe}$, he showed that stimulation of nitrogen fixation occurred at $10^{-6} \mathrm{M} \mathrm{Fe}$ after incubation in iron for two days. Rueter et al. (1990) demonstrated stimulation of nitrogen fixation in cultures of Trichodesmium incubated in iron from $10^{-9}, 10^{-8}$ and $10^{-7} \mathrm{M} \mathrm{Fe}$ after 15 days. Nitrogen fixation was stimulated in the cultures after several days 
following an increase in chlorophyll- $a$. The result being lightdependent nitrogen fixation would be stimulated only after the enhancement of photosynthetic pigments. Rueter et al. (1990) considered the possibility that Trichodesmium may respond to varying amounts of iron in the environment with small physiological changes. In this way Trichodesmium is able to optimize iron usage.

The longest period of time colonies were incubated in iron for acetylene reduction in this thesis was 20 hours. Colonies were incubated in January 1992 in $\mathrm{FeCl}_{3}\left(1.8 \times 10^{-7}\right)$, dust $(20 \mathrm{mg}$ in 200 mI FSW) and FeEDTA $\left(10^{-7} \mathrm{M}\right)$ (TABLE III). The results did not show any stimulation of nitrogen fixation. This experiment was repeated with blue water dive collected colonies with the exception of EDTA $\left(10^{-6}\right)$ replacing FeEDTA but with similar results (TABLE III). This may not be long enough to get a physiological response of increased nitrogen fixation rates with iron additions. However, Paerl et al. (1994) demonstrated stimulation of nitrogen fixation with $1 \mu \mathrm{M} \mathrm{Fe}$ as FeEDTA in "short term" (24-48 hours) and "long term" (5-11 days) incubations. Ambient dissolved iron concentrations in the N. Atlantic Ocean are approximately between 0.2 and $0.6 \mathrm{nM}$ in the euphotic zone (Powell et al. 1994). Natural populations of Trichodesmium colonies are never exposed to iron concentrations as high as $1 \mu \mathrm{M}$. Perhaps high iron concentrations stimulate other iron uptake systems that are normally secondary or induce synthesis of iron uptake proteins. Only the dust concentrations in this thesis were $\mu \mathrm{M}$ $(4.5 \mu \mathrm{M})$. Stimulation of nitrogen fixation did not occur and in most cases, average $A R$ rates were slightly lower than control (no $\mathrm{Fe}$ ). 
Another problem with the incubations in this thesis are bottle effects. Trichodesmium colonies that were incubated overnight in no Fe were compared to colonies freshly collected the next morning. Incubated controls had lower $\mathrm{AR}$ rates indicating effects from being contained in the flasks. Lack of stimulation of nitrogen fixation with iron additions could be due to the fact that colonies could not be kept in good enough condition long enough to observe a change in nitrogenase activity.

Possibly what is more significant in these experiments are the shorter term incubations where iron was added directly to the acetylene reduction vial or incubated 1-2 hours (TABLE II). Since colonies can have protein- $\mathrm{N}$ to iron ratios approaching 3000 and the colonies can actively fix nitrogen on low cellular iron, this develops an hypothesis that the colonies may not be iron-limited. Perhaps, iron additions added to colonies may not be needed during the nitrogen fixation phase of that day. The extra iron might be taken up without an instantaneous change in physiology but with changes in proteins. Evidence for this is seen in the Western blots for the iron protein of nitrogenase (Figure 18). Repeatedly in the Caribbean Sea populations, colonies incubated in iron or dust had both forms of the iron protein when the control did not. This may be a precursor to higher nitrogenase activity in the future. Iron additions also induced changes in unknown proteins with SDS-PAGE (Figure 12) which is similar to changes in the iron protein. 


\section{Conclusion}

Trichodesmium protein and iron content can vary over diel time scales and within populations and appears to be related to the growth phase of that population. Higher protein-N to iron ratios exist for Trichodesmium than previously thought indicating that this organism is adapted to low cellular iron levels. This is supported by a lack of stimulation of nitrogen fixation rates with near ambient iron concentrations. Changes in the iron protein of nitrogenase and an unknown protein(s) were observed with iron additions that may be a more subtle response to iron nutrition. Diel studies of the changes in the iron protein of nitrogenase offer evidence that natural populations of Trichodesmium in the Caribbean Sea have reversible modification of the iron protein. Trichodesmium colonies in the cooler Sargasso Sea in spring do not show a diel change in subunits of the iron protein of nitrogenase when nitrate is present in the water column. These environmental conditions alter the colony morphology and physiology of Trichodesmium colonies in this seasonal environment. 


\section{REFERENCES}

Bergersen, B. F. 1970. The quantitative relationship between nitrogen fixation and the acetylene reduction assay. Australian Journal of Biological Science 23:1015-1025

Bergman, B. and E.J. Carpenter. 1991. Nitrogenase confined to randomly distributed trichomes in the marine cyanobacterium Trichodesmium thiebautii. Journal of Phycology 27: 158-165

Borstad, G. A. 1978. Some aspects of the biology and hydrography of Trichodesmium (Cyanophyta) in the Western Tropical Atlantic near Barbados, West Indies. PhD thesis, McGill University, Montreal, Canada, 234p.

Briat, F. F., J. P. Laulhere, A. M. Laboure, D. Proudhon and A. M. Lescure. 1988. Structure, function and synthesis of plant ferritins. In: Metal Ion Homeostasis-Molecular Biology and Chemistry. Hamer, D. H. and D. R. Winge (Eds.) New York

Bryceson, I. and P. Fay. 1981. Nitrogen fixation in Oscillatoria (Trichodesmium) erythraea in relation to bundle formation and trichome differentiation. Marine Biology 61:159-166

Capone, D.G. 1993. Determination of nitrogenase activity in aquatic samples using the acetylene reduction procedure. In: Handbook of Methods in Aquatic Microbial Ecology. Kemp, P. F., B. F. Sherr, E. B. Sherr and J. J. Cole (Eds.) Lewis, Boca Raton

k Capone, D. G. and E. J. Carpenter. 1982. Nitrogen in the marine environment. Science 217: 1140-1142

Capone, D.G., J. M. O'Neil, J. Zehr, E. J. Carpenter. 1990. Basis for Diel Variation in Nitrogenase Activity in the Marine Planktonic Cyanobacteria Trichodesmium thiebautii Applied and Environmental Microbiology 56 3532-3536 
Carpenter, E. J. 1973. Nitrogen fixation by Oscillatoria (Trichodesmium) in the southwestern Sargasso Sea. DeepSea Research 20: 285-288

X Carpenter, E.J. 1983a. Nitrogen fixation by marine Oscillatoria (Trichodesmium) in the world's oceans. In: Nitrogen in the Marine Environment. Carpenter, E.J. and D.G. Capone (Eds.) Academic Press, New York

Carpenter, E. J. 1983b. Physiology and Ecology of Marine Planktonic Oscillatoria (Trichodesmium). Marine Biology Letters 4: 69-85

Carpenter, E. J. and J. J. McCarthy. 1975. Nitrogen fixation and uptake of combined nitrogenous nutrients by Oscillatoria (Trichodesmium) thiebautii in the western Sargasso Sea. Limnology and Oceanography 20 (3): 389-401

Carpenter, E. J. and C. C. Price. 1977. Nitrogen fixation, distribution, and production of Oscillatoria (Trichodesmium) spp. in the western Sargasso and Caribbean Seas. Limnology and Oceanography 22(1): $60-72$

Carpenter, E. J., M. I. Scranton, P. C. Novelli and A. Michaels. 1987. Validity of $\mathrm{N}_{2}$ fixation rate measurements in marine Oscillatoria (Trichodesmium). Journal of Plankton Research 9:1047-1056

Carpenter, E. J. and D. G. Capone. 1992. Nitrogen fixation in Trichodesmium blooms. In: Marine Pelagic Cyanobacteria: Trichodesmium and Other Diazotrophs. Carpenter, E. J., D. G. Capone and J. G. Rueter (Eds.) NATO ASI Series C: Mathematical and Physical Sciences-Vol. 362 Kluwer Academic Publishers, Dordrecht

Carpenter, E. J., J. Chang, M. Cottrell, J. Schubauer, H. W. Pearl, B. Bebout and D. G. Capone. 1990. Re-evaluation of nitrogenase oxygen-protective mechanisms in the planktonic marine cyanobacterium Trichodesmium. Marine Ecological Progress Series 65:151-158 
Dayhoff, M. O., L. T. Hunt and S. Hurst-Calderone. 1965. Composition of Proteins. In: Atlas of Protein Structure. Dayhoff, M. O. and O. Margaret (Eds.) National Biomedical Research Foundation, Silver Spring, Md.

Deuser, W. G. 1986. Seasonal and interannual variationsin deepwater particle fluxes in the Sargasso Sea and their relation to surface hydrography. Deep-Sea Research 33:225-246

$\mathrm{Du}, \mathrm{C}$. and J. R. Gallon. 1993. Modification of the Fe protein of nitrogenase of Gloeothece (Nageli) sp. ATCC 27152 during growth under alternating light and darkness. New Phytology 125:121-129

Duce, R. A. 1986. The impact of atmospheric nitrogen, phosphorus, and iron species on marine biological productivity. In: The role of air-sea exchange in geochemical cycling. BuatMenard, P. (Ed.) NATO ASI Series C: Mathematical and Physical Sciences-Vol. 185

Duce, R. A. and N. W. Tindale. 1991. Atmospheric transport of iron and its deposition in the ocean. Limnology and Oceanography 36:1715-1726

Duce, R. A., P. S. Liss, J. T. Merrill, E. L. Atlas, P. Bruat-Menard, B. B. Hicks, J. M. Miller, J. M. Prospero, R. Arimoto, T. M. Church, W. Ellis, J. N. Galloway, L. Hansen, T. D. Jickells, A. H. Knap, K. H. Reinhardt, B. Schneider, A. Soudine, J. J. Tokos, S. Tsunogai, R. Wollast, and M. Zhou. 1991. The atmospheric input of trace species to the world ocean. Global Biochemical Cycles 5:193-259

Dugdale, R. C. and J. J. Goering. 1967. Uptake of new and regenerated forms of nitrogen in primary productivity. Limnology and Oceanography 12: 196-206

Dugdale, R. C., D. W. Menzel and J. H. Ryther. 1961. Nitrogen fixation in the Sargasso Sea. Deep-Sea Research 7: 297-300 
Dugdale, R. C., J. J. Goering and R. H. Ryther. 1964. High nitrogen fixation rates in the Sargasso Sea and Arabian Sea. Limnology and Oceanography 9: 507-510

Elardo, K.M. and J. G. Rueter. 1990. The response of Trichodesmium to soluble iron or dust. 5th N.W. Algal Symposium. Anacortes, Wa.

Elardo, K.M. 1991. Changes in distribution of dinitrogenase reductase subunits of Trichodesmium in response to time of day and iron nutrition. NATO Advanced Research Workshop, Bloomforming Diazotrophic Marine Cyanobacteria. Bamberg, Germany

Elder, J. F. and A. J. Horne. 1977. Biostimulatory capacity of dissolved iron for cyanophycean blooms in a nitrogen-rich resevoir. Chemosphere 9:525-530

Eppley, R. W.,J. L. Coatsworth and L. Solozano. 1969. Studies of nitrate reductase in marine phytoplankton. Limnology and Oceanography 14:194-205

Eppley, R. W. and B. J. Peterson. 1979. Particulate matter flux and planktonic new production in the deep ocean. Nature 282:677-680

Ernst, A., Y.D. Liu, S. Reich, P. Boger. 1990a. Diurnal nitrogenase modification in the cyanobacterium Anabaena variabilis Bot. Acta 103, 183

Ernst,A., S. Reich, P. Boger. 1990b. Modification of dinitrogenase reductase in the cyanobacterium Anabaena variabilis due to $\mathrm{C}$ starvation and ammonia Journal of Bacteriology 172: $748-755$

Fay, P. 1992. Oxygen relations of nitrogen fixation in cyanobacteria. Microbial Reviews 56: 340-373

Gaal, O., G. A. Medgyesi, L. Vereczkey. 1980. Electrophoresis in the separation of biological macromolecules. p. 258 Wiley 
Gallon, J. R. 1981. The oxygen sensitivity of nitrogenase: a problem for biochemists and micro-organisms. Trends in Biochemical Science 6:19-23

Gallon, J. R. 1989. The physiology of $\mathrm{N}_{2}$ fixation by non-heterocystous cyanobacteria. Phykos 28:18-46

Gallon, J. R. 1992. Reconciling the incompatible: $\mathrm{N}_{2}$ fixation and $\mathrm{O}_{2}$. Tansley Review no. 44. New Phytologist 122: 571-609

Goering, J. J., R. C. Dugdale and D. W. Menzel. 1966. Estimates of in situ rates of nitrogen uptake by Trichodesmium sp. in the tropical Atlantic Ocean. Limnology and Oceanography 11:614-620

Gibbs, M. M. 1979. A simple method for the rapid determination of iron in natural waters. Water Research 13:295-297

Grill, E., E-L Winnacker and M. H. Zenk. 1987. Phytochelatins, a class of heavy-metal-binding proteins from plants, are functionally analogous to metallothioneins. Proceedings from the National Academy of Science 84:439-443

Howarth, R. W., R. Marino and J. Lane. 1988. Nitrogen fixation in freshwater, estuarine, and marine ecosystems. 1. Rates and importance. Limnology and Oceanography 33:669-687

Hutchins, D. A. 1989. Nitrogen and iron interactions in filamentous cyanobacteria. M. S. thesis, Portland State University, Portland, Oregon, $116 \mathrm{p}$.

Kana, T. M. 1993. Rapid oxygen cycling in Trichodesmium thiebautii. Limnology and Oceanography 38: 18-24

Karl, D., Letelier, R., Hebel, D.V., Bird, B.F. \& Winn, C.D. 1992.

Trichodesmium blooms and new nitrogen in the north

Pacific gyre. In: Marine Pelagic Cyanobacteria:

Trichodesmium and other diazotrophs. Carpenter, E., D.

Capone \& J. Rueter (Eds.). NATO ASI-Series. Series C: Mathematical and Physical Sciences Vol. 362. Kluwer Academic Publishers, Dordrecht 
Knap, A, T. Jickells, A. Pzenny and J. Galloway. 1986. Significance of atmospheric-derived fixed nitrogen on productivity of the Sargasso Sea. Nature 320:158-160

Laemmli, U. K. 1970. Cleavage of structural proteins during assembly of the head of bacteriophage T4. Nature 227: 680-685

Laulhere, J.-P., A.-M. Laboure, O. Van Wuytswinkel, J. Gagnon and J.F. Briat. 1992. Purification, characterization and function of bacterioferritin from the cyanobacteria Synechocystis P.C.C. 6803. Biochemistry Journal 281:785-793

Legendre, L., and M. Gosselin. 1989. New production and export of organic matter to the deep ocean: Consequences of some recent discoveries. Limnology and Oceanography 34: $1374-1380$

Lohrenz, S. E., G. A. Knauer, V. L. Asper, M. Tuel, A F. Michaels, and A. H. Knap. 1992. Seasonal variability in primary production and particle flux in the northwester Sargasso Sea: U. S. JGOFS Bermuda Atlantic Time-series Study. Deep-Sea Research 39:1373-1391

Ludden, P. W. and R. H. Burris. 1978. Purification and properties of nitrogenase from Rhodospirillum rubrum, and evidence for phosphate, ribose and an adenine-like unit covalently bound to the iron protein. Biochemistry Journal 175:251259

Martin, J. H. and R. M. Gordon. 1988. Northeast Pacific iron distributions in relation to phytoplankton productivity. Deep-Sea Research 35:176-196

Martin, J. H. and S. F. Fitzwater. 1988. Iron deficiency limits phytoplankton growth in the north-east Pacific subartic. Nature 331:341-343

Martin, J. H., R. M. Gordon, S. Fitzwater and W. W. Broenkow. 1989. VERTEX: phytoplankton/iron studies in the Gulf of Alaska. Deep-Sea Research 36:649-680 
Martin, J. H., R. M. Gordon S. E. Fitzwater. 1991. The case for iron. Limnology and Oceanography 36:1793-1802

McCarthy, J. J. and E. J. Carpenter. 1979. Oscillatoria (Trichodesmium) thiebautii (Cyanophyta) in the Central North Atlantic Ocean. Journal of Phycology 15: 75-82

Menzel, D. W. and J. H. Ryther. 1960. The annual cycle of primary production in the Sargasso Sea off Bermuda. Deep-Sea Research 6:351-367

Menzel, D. W. and J. H. Ryther. 1961. Nutrients limiting the production of phytoplankton in the Sargasso Sea, with special reference to iron. Deep-Sea Research 7:276-281

Menzel, D. W., E. M. Hulbert and J. H. Ryther. 1963. The effects of enriching Sargasso Sea water on the production and species composition of the phytoplankton. Deep-Sea Research 10:209-219

Michaels, A. F., A. H. Knap, R. L. Dow, K. Gundersen, R. J. Johnson, J. Sorensen, A. Close, G. A. Knauer, S. E. Lohrenz, V. A. Asper, M. Tuel and R. Bridigare. 1994. Seasonal patterns of ocean biogeochemistry at the U. S. JGOFS Bermuda Atlantic Timeseries Site. Deep Sea Research 41:1013-1038

Moore, R. M., J. E. Milley and A. Chatt. 1984. The potential for biological mobilization of trace elements from aeolian dust in the ocean and its importance in the case of iron. Oceanologica ACTA 7:221-228

Ohki, K., P. G. Falkowski, J. G. Rueter, and Y. Fujita. 1991a.

Experimental study of the marine cyanophyte Trichodesmium sp., a nitrogen-fixing phytoplankton in tropical and subtropical sea area. Marine Biology, Its Accomplishment and Future Prospect. Proc. 5th Symp. Int. Prize Biol. Hokusensha 
Ohki, K., J.P. Zehr, P.G. Falkowski, and Y. Fujita. 1991b. Regulation of nitrogen-fixation by different nitrogen sources in the marine non-heterocystous cyanobacterium Trichodesmium sp. NIBB1067 Archives of Microbiology 156:335-3371

Ohki, K., J. P. Zehr and Y. Fujita. 1992. Regulation of nitrogenase activity in relation to the light-dark regime in the filamentous non-heterocystous cyanobacterium Trichodesmium sp. NIBB 1067. Jounal of General Microbiology 138:2679-2685

Orme-Johnson, W. H. 1992. Nitrogenase structure: where to now? Science 257:1639-1640

Paerl, H. W. and B. M. Bebout. 1988. Direct measurement of $\mathrm{O}_{2}-$ depleted microzones in marine Oscillatoria: relation to $\mathrm{N}_{2}$ fixation. Science 241:442-445

Paerl, H. W., L. E. Prufert-Bebout and C. Guo. 1994. Iron-stimulated $\mathrm{N}_{2}$ fixation and growth in natural and cultured populations of the planktonic marine cyanobacteria Trichodesmium spp. Applied and Environmental Microbiology 60:10441047

Parsons, T. R., M. Takahashi and B. Hargrave. 1984. Biological Oceanographic Processes. 3rd Edition. Pergamon Press, Oxford

Pope, M. R., S. A. Murrell and P. W. Ludden. 1985. Covalent modification of the iron protein of nitrogenase from Rhodospirillum rubrum by adenosine diphosphorylation of a specific arginine residue. Proceedings of the National Academy of Sciences U. S. A. 82:3173-3177

Powell, R. T., B. L. Lewis and W. M. Landing. 1994. Dissolved and particulate iron in the Atlantic Ocean. Submitted to Marine Chemistry 
Preston, G.G. and Ludden, P.W. 1982. Change in subunit Composition of the Iron Protein of nitrogenase from Rhodospirillum rubrum during activation and inactivation of the Iron Protein Biochem. J. 205, 489-494

Reich, S. and P. Boger. 1989. Regulation of Nitrogenase Activity in Anabaena variabilis by Modification of the Fe Protein FEMS Microbiology Letters 58, 81-86

Rich, H. W. and F. M. M. Morel. 1990. Availability of well-defined iron colloids to the marine diatom Thalassiosira weissflogii. Limnology and Oceanography 35:652-662

Rueter, J. G. 1988a. Iron stimulation of photosynthesis and nitrogen fixation in Anabaena 7120 and Trichodesmium (Cyanophyceae). Journal of Phycology 24:249-254

Rueter, J. G. 1988b. Iron and nitrogen content of Trichodesmium. EOS 69:1089

Rueter, J. G. and D. R. Ades. 1987. The role of iron nutrition in photosynthesis and nitrogen assimilation in Scenedesmus quadricauda (Chlorophyceae). Journal of Phycology $23: 452-457$

Rueter, J. G., K. Ohki and Y. Fujita. 1990. The effect of iron nutrition on photosynthesis and nitrogen fixation in cultures of Trichodesmium (Cyanophyceae). Journal of Phycology 26:30-35

Rueter, J. G. and N. L. Unsworth. 1991. Response of marine Synecoccocus (Cyanophyceae) cultures to iron nutrition. Journal of Phycology 27:173-178

Rueter, J. G., D. A. Hutchins, R. W. Smith and N. L. Unsworth. 1992. Iron nutrition of Trichodesmium. In: Marine Pelagic Cyanobacteria: Trichodesmium and Other Diazotrophs. Carpenter, E. J., D. G. Capone and J. G. Rueter (Eds.) NATO ASI Series C: Mathematical and Physical Sciences-Vol. 362 Kluwer Academic Publishers, Dordrecht 
Ryther, J. H.and R. R. L. Guillard. 1959. Enrichment experiments as a means of studying nutrients limiting to phytoplankton production. Deep-Sea Research 6:65-69

Saino, T. and A. Hattori. 1978. Diel variation in nitrogen fixation by a marine blue-green alga, Trichodesmium thiebautii. DeepSea Research 25:1259-1263

Saino, T. and A. Hattori. 1982. Aerobic nitrogen fixation by the marine non-heterocystous cyanobacterium Trichodesmium (Oscillatoria) spp. : its protective mechanism against oxygen. Marine Biology 70:251-254

Schagger, H. and G. von Jagow. 1987. Tricine-sodium dodecyl sulfatepolyacrylamide gel electrophoresis for the separation of proteins in the range from 1 to $100 \mathrm{kDa}$. Analytical Biochemistry 166:368-379

Scranton, M. I. 1983. The role of the cyanobacterium Oscillatoria (Trichodesmium) thiebautii in the marine hydrogen cycle. Marine Ecology Progress Series 11:79-87

Scranton, M. I. 1984. Hydrogen cycling in the waters near Bermuda: the role of the nitrogen fixer, Oscillatoria thiebautii. DeepSea Research 31: 133-143

Scranton, M. I., P. C. Novelli, A. Michaels, S. G. Horrigan, E. J. Carpenter. 1987. Hydrogen production and nitrogen fixation by Oscillatoria thiebautii during in situ incubations. Limnology and Oceanography 32:988-1006

Smith, R.L., Chase,V.B., Tabita, R.F. (1987) Alteration of the Fe Protein of Nitrogenase by Oxygen in the Cyanobacterium Anabaena sp. Strain CA Journal of Bacteriology $1692537-2542$

Stookey, L. L. 1970. Ferrozine-a new spectrophotometric reagent for iron. Analytical Chemistry 42:779-781

Subba Roa, D. V. and P. A. Yeats. 1984. Effect of iron on phytoplankton production in the Sargasso Sea. J. Exp. Mar. Biol. Ecol. 81:281-289 
Thiel, E. C. 1987. Ferritin: structure, gene regulation, and cellular function in animals, plants, and microorganisms. Annual Review of Biochemistry 56:289-315

Uriel, J. and S. Chuilon. 1965. In: Methods in Immunology and Immunochemistry. Williams, C. A. and M. W. Chase (Eds.). Academiic Press, New York. Vol. 3., P. 304

Wells, M. L. and L. M. Mayer. 1991. The photoconversion of colloidal iron hydroxides in seawater. Deep-Sea Research 38:13791395

Wurtsbaugh, W. A. and A. J. Horne. 1983. Iron in eutrophic Clear Lake, California: its importance for algal nitrogen fixation and growth. Can. J. Aquat. Sci. 40:1419-1429

Wurtsbaugh, W. A., W. F. Vincent, R. Alfaro Tapia, C. L. Vincent and P. J. Richerson. 1985. Nutrient limitation of algal growth and nitrogen fixation in atropical alpine lake, Lake Titicaca (Peru/Bolivia). Freshwater Biology 15:185-195

Zehr, J. P., R. J. Limberger, K. Ohki and Y. Fujita. 1990. Antiserum to nitrogenase generated from an amplified DNA fragment from natural populations of Trichodesmium spp. Applied and Environmental Microbiology 56:3527-3531

Zehr, J. P., M. Wyman, V. Miller, L. Duguay and D. G. Capone. 1993. Modification of the $\mathrm{Fe}$ protein of nitrogenase in natural populations of Trichodesmium thiebautii. Applied and Environmental Microbiology 59: 669-676 


\section{APPENDIX I}

\subsection{Ionic strenght buffer}

\section{(Tris-HCL buffer)}

$0.1 \mathrm{M} \mathrm{NaCl}, 0.01 \mathrm{M} \mathrm{MgCl}_{2}, 0.01 \mathrm{M} \mathrm{Ca} \mathrm{Cl}_{2}, 50 \mathrm{ml}$. of $1 \mathrm{M} \mathrm{HCl}$, titrated to $\mathrm{pH} 7.5$ with $1 \mathrm{M}$ Tris

\section{Attempt 1}

Thirty to fifty colonies were placed into $50 \mu \mathrm{l}$ of $0.05 \mathrm{I}$ buffer and 44 colonies were placed on a $0.45 \mu \mathrm{m}$ Millipore filter (HA) attached to a $12 \mathrm{cc}$ syringe fitted with a Millipore Swinex-13 filter rig clamped vertically on a ring stand (Figure ). Gentle suction was employed to rinse off the sample on the filter with 100 ul of 0.05 I-buffer to reduce saltwater effects on matrix of gel. The sample was then scraped off the filter with a pipette tip and placed in $50 \mu 1$ of 0.05 I-buffer. SDS sample buffer $(0.0625 \mathrm{M}$ tris-OH, $2 \%$ SDS, $10 \%$ glycerin, $0.001 \mathrm{M}$ EDTA, and $0.01 \%$ bromophenyl blue) was made fresh from $2 \mathrm{X}$ stock and prepared immediately before use by adding $0.8 \mathrm{ml}$ of phenylmethlysulfonyl fluoride (PMSF) stock solution (3 $\mathrm{mg}$ PMSF/0.5 ml ethanol made immediately prior to use and kept on ice) and $50 \mathrm{mM}$ dithiothreitol. Immediately following the preparation of sample buffer, $50 \mu \mathrm{l}$ of prepared sample buffer was added to all samples. Samples were ground with a pipette tip and boiled for 1.5 minutes to denature the protein and then centrifuged at $6,000 \mathrm{~g}$ for 2 minutes. The samples were stored at $-4{ }^{0} \mathrm{C}$ and run on a $214 \%$ SDS gels at $200 \mathrm{~V}$ for 30 minutes. All samples showed smearing but the 
sample placed on the Millipore filter prior to buffer addition showed less smearing. High molecular weight bands were detected.

\section{Attempt 2:}

Colonies to SDS buffer ratio was 1:1 (40 colonies to 40 ul SDS sample buffer buffer) and 1:2 (20 colonies to $40 \mathrm{ul} \mathrm{SDS} \mathrm{sample}$ buffer). One sample from each condition was flash frozen in liquid nitrogen for $2 \mathrm{~min}$. prior to solubilization. The loading volumes were similar to the first attempt, 10 and $15 \mathrm{ul}$, on a $14 \%$ gel run at $200 \mathrm{~V}$ for $30 \mathrm{~min}$ ( $100 \mathrm{~V}$ per gel) but there was no improvement observed. In an attempt to isolate the reason for the poor resolution, samples were run that were prepared using a different SDS sample buffer (Zehr 1990). There was was no appreciable improvement in resolution in these gels.

The gels were smearing in the low molecular weight range (including the molecular weight standard) and it was thought that this might be due to heat. The previous gels were run at $100 \mathrm{~V}$ per gel $(200 \mathrm{v}$ per two gels) so the voltage was decreased to $90 \mathrm{~V}$. The samples in this run were diluted $1: 4$ (20 colonies: 80 ul buffer) as this combination gave good results. There was still no appreciable improvement.

Solutions for $12 \%$ SDS PAGE stock solutions:

Resolving gel

$2.94 \mathrm{ml}$ acrylamide $30 \%, 0.94 \mathrm{ml}$ resolving buffer , $1.11 \mathrm{ml} \mathrm{dH} 20,75$ $\mu \mathrm{l}$ SDS $10 \%, 0.94 \mathrm{ml}$ bis $2 \%, 1.5 \mathrm{ml}$ glycerol $50 \%$

$45 \mu \mathrm{l}$ APS $10 \%, 4.5 \mu 1$ TEMED 
Stacking gel

$0.67 \mathrm{ml}$ acrylamide $30 \%, 1.0 \mathrm{ml}$ stacking buffer, $1.95 \mathrm{ml} \mathrm{dH} 20,40 \mu \mathrm{l}$ SDS $10 \%, 0.29 \mathrm{ml}$ bis $2 \%, 33.3 \mu \mathrm{l}$ APS $10 \%, 3.33 \mu 1$ TEMED

Resolving buffer

$36.3 \mathrm{~g}$ Tris $\mathrm{pH} 8$ with aproximately $48 \mathrm{ml} 1.0 \mathrm{M} \mathrm{HCl}$ to final volume of $100 \mathrm{ml}$

\section{Stacking buffer}

$60 \mathrm{~g}$ Tris $\mathrm{pH} 6.8$ with aproximately $48 \mathrm{ml}$ of $1.0 \mathrm{M} \mathrm{HCl}$ to final volume of $100 \mathrm{ml}$

Protein Solubilization Buffer (SDS sample buffer)

$1 \%$ SDS, $50 \mathrm{mM}$ Tris, 5\% beta-mercaptoethanol, $2 \mathrm{mM}$ PMSF, $1 \mathrm{mM}$ EDTA, $10 \%$ glycerol, $0.2 \mathrm{mg} . / \mathrm{mL}$. bromophenol blue

Electrode Buffer $5 \mathrm{x}$

$7.5 \mathrm{~g}$ Tris- $\mathrm{OH}, 36 \mathrm{~g}$ glycine, $2.5 \mathrm{~g}$ SDS to final volume of $500 \mathrm{ml}$

Coomassie Stain

$25 \%$ isopropyl alcohol, $10 \%$ acetic acid and $.025 \%$ coomassie blue $\mathrm{R}-250$

Destaining Solution

$10 \%$ acetic acid 
Appendix II

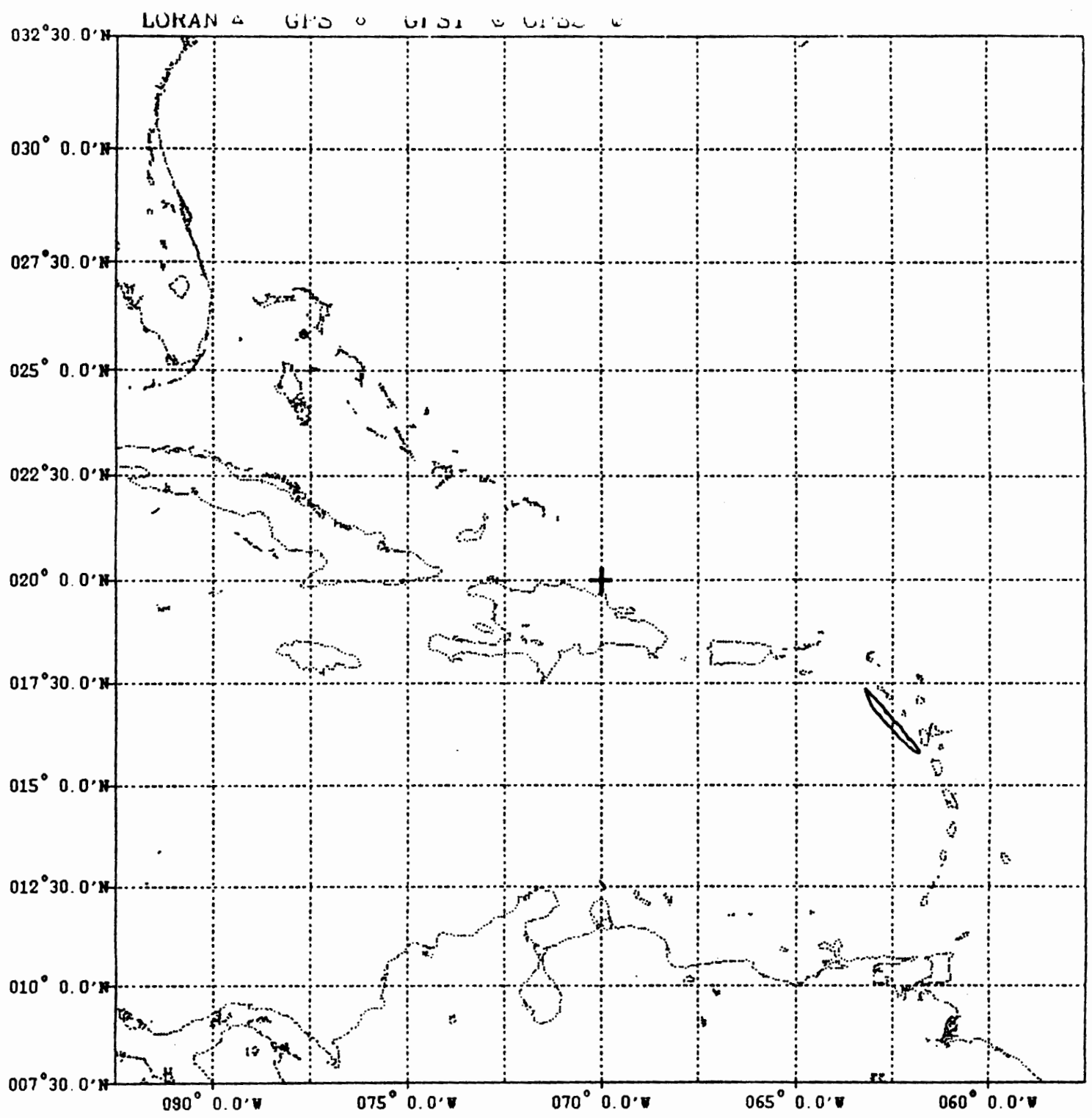

Location of cruise track (inside circle) in the Carribbean Sea. 